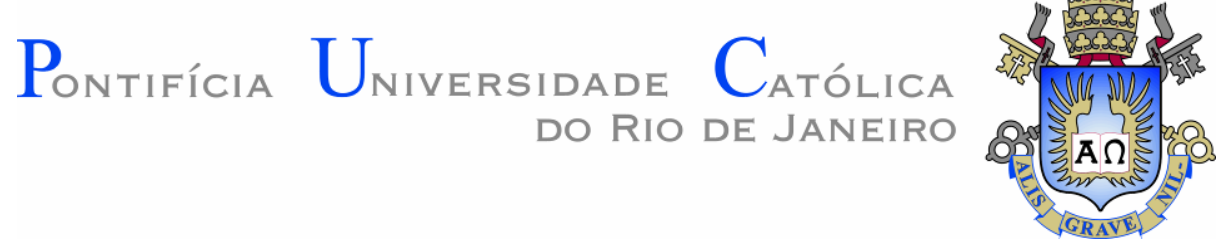

Mariana dos Santos Motta

Fluência e retração de pastas de cimento em idade jovem

Dissertação de Mestrado

Dissertação apresentada como requisito parcial para obtenção do grau de Mestre pelo Programa de PósGraduação em Engenharia Civil do Departamento de Engenharia Civil e Ambiental da PUC-Rio.

Orientador: Prof. Flávio de Andrade Silva Coorientadora: Drạ . Lourdes Maria Silva de Souza

Rio de Janeiro Setembro de 2018 


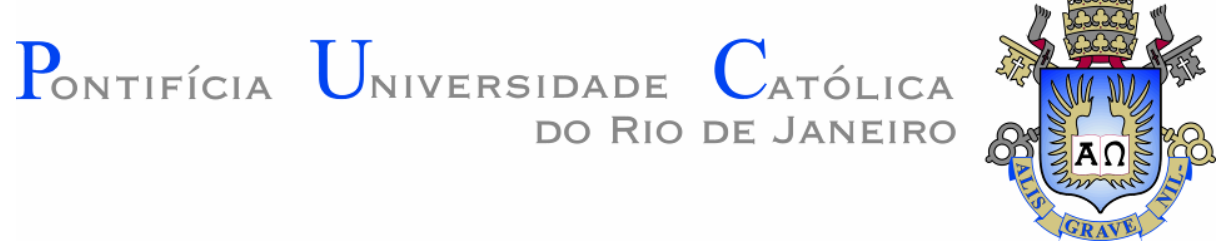

Mariana dos Santos Motta

\title{
Fluência e retração de pastas de cimento em \\ idade jovem
}

Dissertação apresentada como requisito parcial para obtenção do grau de Mestre pelo Programa de PósGraduação em Engenharia Civil da PUC-Rio. Aprovada pela Comissão Examinadora abaixo assinada.

\author{
Dra. Lourdes Maria Silva de Souza \\ Co-Orientadora \\ Instituto TECGRAF - PUC-Rio
}

Prof. Daniel Carlos Taissum Cardoso

Departamento de Engenharia Civil e Ambiental- PUC-Rio

Prof ${ }^{a}$. Janine Domingos Vieira Universidade Federal Fluminense

Prof. Márcio da Silveira Carvalho

Coordenador Setorial do

Centro Técnico Científico - PUC-Rio

Rio de Janeiro, 21 de setembro de 2018. 
Todos os direitos reservados. É proibida a reprodução total ou parcial do trabalho sem autorização da universidade, da autora e do orientador.

\section{Mariana dos Santos Motta}

Graduada em Engenharia Civil pela Pontifícia Universidade Católica do Rio de Janeiro - PUC-Rio - em 2016. Principais áreas de interesse: Materiais compósitos, fluência, retração.

Ficha Catalográfica

Motta, Mariana dos Santos

Fluência e retração de pastas de cimento em idade jovem / Mariana dos Santos Motta; Orientador: Flávio de Andrade Silva; Coorientadora: Lourdes Maria Silva de Souza - 2018.

v. 125 f.: il. color; $29,7 \mathrm{~cm}$.

1. Dissertação (mestrado) - Pontifícia Universidade Católica do Rio de Janeiro, Departamento de Engenharia Civil e Ambiental.

Inclui referências bibliográficas.

1. Engenharia Civil e Ambiental - Teses. 2. Fluência. 3. Retração. 4. Idade jovem. 5. Fibras. I. Silva, Flávio de Andrade. II. Souza, Lourdes Maria Silva de. III. Pontifícia Universidade Católica do Rio de Janeiro. Departamento de Engenharia Civil e Ambiental. IV. Título. 


\section{Agradecimentos}

Gostaria de agradecer ao meu orientador Flavio e à minha coorientadora Lourdes por toda a assistência e paciência durante a execução deste trabalho e por todos os conselhos e ensinamentos que me ajudaram a concluí-lo.

Aos funcionários do LEMDEC da PUC-Rio, Bruno, Rogério, Zé e Carlos, por toda disponibilidade e ajuda que me proporcionaram. Em especial gostaria de agradecer ao Marques, por toda a eficiência e paciência na usinagem do pórtico da fluência e no suporte da retração autógena, e ao Euclides, por todo desenvolvimento dos programas utilizados na pesquisa, além de todo apoio, carinho e confiança dados a mim durante esta difícil trajetória.

Aos meus queridos pais, Fátima e Charles, por todo suporte financeiro e principalmente emocional, pelo apoio incondicional. Se não fossem por eles, certamente não teria conseguido concluir este projeto. Aos meus queridos irmãos, Júlio e Felipe, por acreditarem na minha capacidade de desenvolver esta pesquisa.

Aos amigos feitos na PUC, que compartilharam os sofrimentos, inseguranças e angustias, e que tornaram o dia a dia mais leve e sorridente, fosse na hora do almoço ou no bar. Em especial à Letícia, Victor e Felipe, amigos queridos que o mestrado me proporcionou e que me ajudaram tanto no desenvolvimento deste trabalho quanto nos momentos de distração que se fizeram necessários.

Às amizades de fora da PUC, que tiveram paciência, entenderam minha ausência em muitos momentos e me fizeram sair do mundo acadêmico em momentos cruciais.

Á LafargeHolcim pelo fornecimento do cimento classe G. Fernando Ribeiro, muito obrigada por toda a disponibilidade.

E à Viapol pelo fornecimento da fibra de polipropileno utilizada nesta pesquisa. Darlan Neves e Gustavo Polidoro, muito obrigada. 


\section{Resumo}

dos Santos Motta, Mariana; de Andrade Silva, Flávio (Orientador); Silva de Souza, Lourdes Maria (Coorientadora). Fluência e retração de pastas de cimento em idade jovem. Rio de Janeiro, 2018. 125p. Dissertação de Mestrado - Departamento de Engenharia Civil e Ambiental, Pontifícia Universidade Católica do Rio de Janeiro.

O presente trabalho tem como objetivo investigar o efeito da adição de fibras dispersas de polipropileno e de curauá na fluência básica a compressão e na retração autógena e por secagem de pastas de cimento nas primeiras idades. $\mathrm{O}$ comprimento das fibras de polipropileno e de curauá foi de $12 \mathrm{~mm}$ e a fração volumétrica variou de 0,03 a $0,30 \%$ da massa do cimento. As pastas de cimento tinham relação água/cimento de 0,44. A retração autógena foi estudada pelo método do tubo corrugado, acompanhando a variação do comprimento desde as primeiras horas. A avaliação da retração por secagem livre se deu por meio da medição da variação de comprimento de primas durante os primeiros dias de idade. Utilizou-se o método do teste do anel para observação do comportamento das pastas sob retração restrita no intuito de se obter a idade de fissuração de cada pasta. A abertura dessas fissuras também foi acompanhada com auxílio de um microscópio. Testes de fluência a compressão foram realizados para determinar a deformação por fluência em idade jovem. Foi observada uma redução significativa da retração autógena nas pastas reforçadas com $0,30 \%$ fibras de curauá. A adição de ambas as fibras reduziu ligeiramente a retração por secagem livre, não tendo diferença significativa entre os teores de fibras. Também foi observado atraso no desenvolvimento de fissuras e redução na abertura de fissuras para ambas as fibras independente do teor. As pastas com adição de fibras exibiram, no geral, uma ligeira melhora na deformação por fluência.

\section{Palavras-chave}

Fluência; retração; idade jovem; fibras. 


\section{Abstract}

dos Santos Motta, Mariana; de Andrade Silva, Flávio (Advisor); Silva de Souza, Lourdes Maria (Co-advisor). Early age creep and shrinkage of cement pastes. Rio de Janeiro, 2018. 125p. Dissertação de Mestrado Departamento de Engenharia Civil e Ambiental, Pontifícia Universidade Católica do Rio de Janeiro.

The present research aims to investigate the effect of the addition of discrete polypropylene and curauá fibers on the early age autogenous and drying shrinkage and basic creep in compression in cement pastes. The length of the polypropylene and curauá fibers was $12 \mathrm{~mm}$ and the volume fraction varied from 0.03 to $0.30 \%$ of the mass content of cement. The cement pastes had water to cement ratio (w/c) of 0.44. Autogenous shrinkage tests were carried out following the Corrugated Tube Method, monitoring the length changes since casting. The evaluation of free drying shrinkage was given by measuring the length changes during the first days of age. The ring test method was used to determine the age when cracking occurred. The crack opening of the samples was also monitored by a microscope. Compressive creep tests were performed with cylindrical specimens to determine the early age creep strain. A significant reduction of the autogenous shrinkage was observed in the specimens with $0.30 \%$ of curauá fibers. The addition of both fibers slightly reduced the free drying shrinkage of the specimens and the fiber content did not appear to influence significantly the shrinkage behavior of the specimens. A delay in the development of cracks and a reduction in crack opening for specimens with both fibers were also observed. This behavior was similar for all fiber content. Pastes reinforced with fibers exhibited, overall, a slight improvement in creep strain. The addition of $0.30 \%$ of polypropylene fibers showed greater improvement in creep strain.

\section{Keywords}

Creep; shrinkage; early age; fibers. 


\section{Sumário}

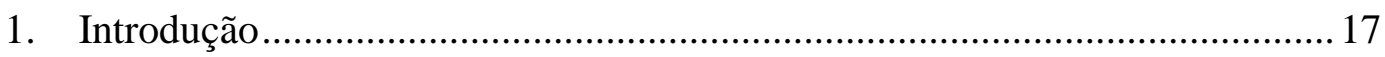

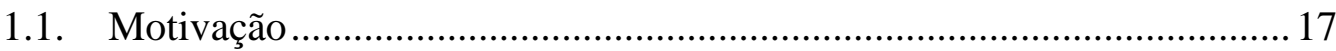

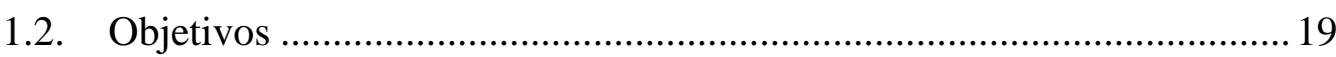

1.3. Organização do Trabalho .................................................................... 19

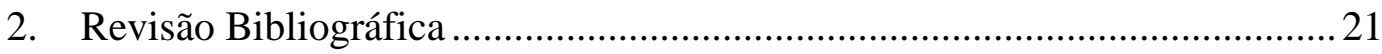

2.1. Tipos de Deformação ....................................................................... 21

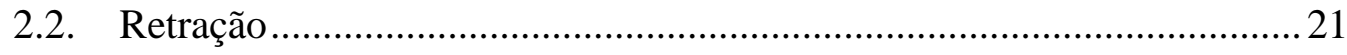

2.2.1. Mecanismos da retração ...................................................... 21

2.2.2. Fatores que influenciam a retração.............................................. 23

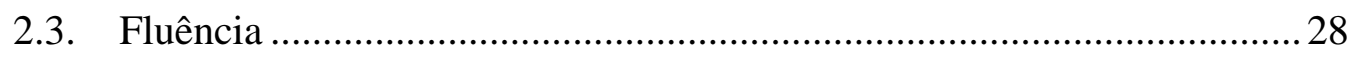

2.3.1. Mecanismos da fluência............................................................ 28

2.3.2. Fatores que influenciam a fluência ................................................ 33

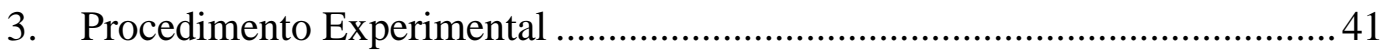

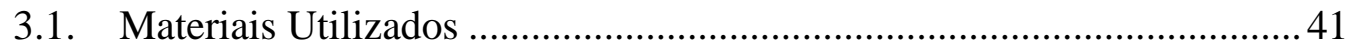

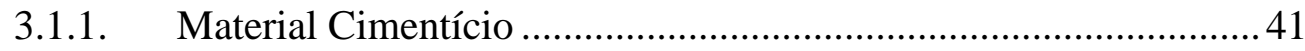

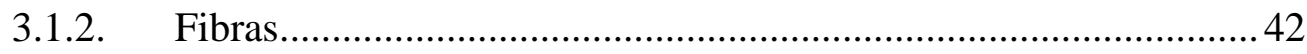

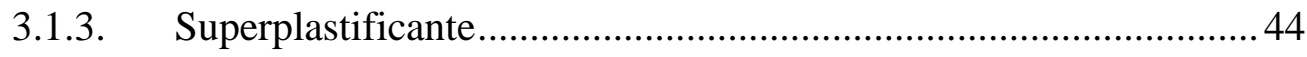

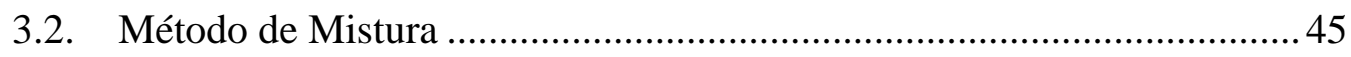

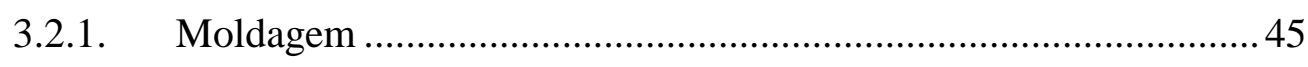

3.2.2. Identificação dos corpos de prova................................................. 47

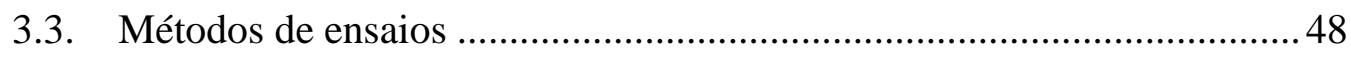

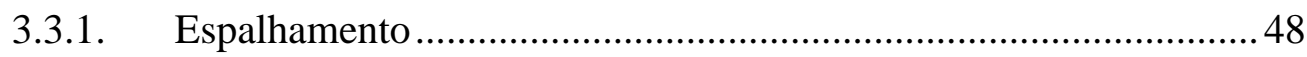

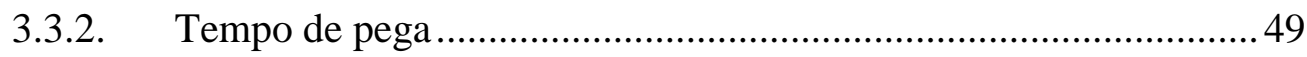

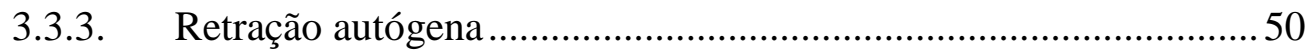

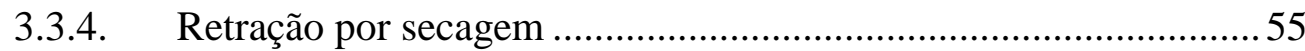




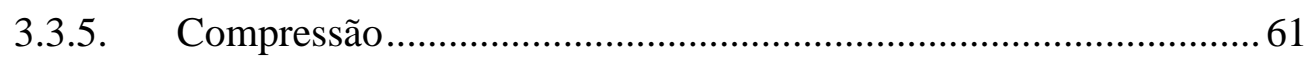

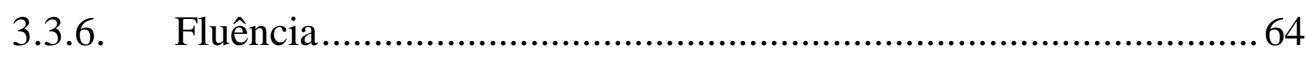

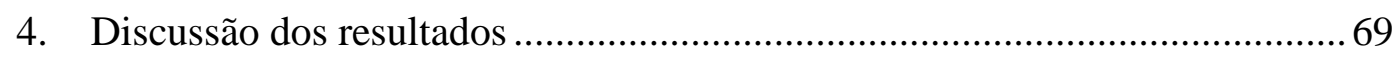

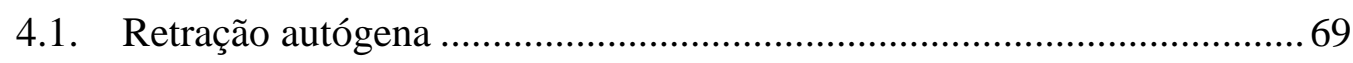

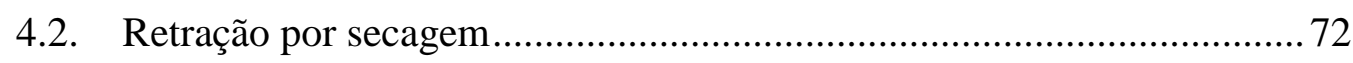

4.2.1. Influência das fibras na retração livre.......................................... 72

4.2.2. Influência das fibras na perda de massa...................................... 76

4.2.3. Influência das fibras na retração com restrição.............................. 78

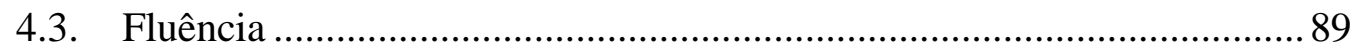

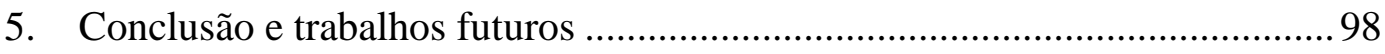

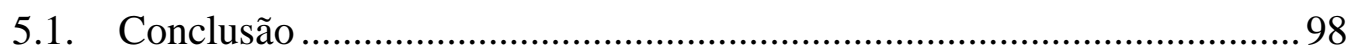

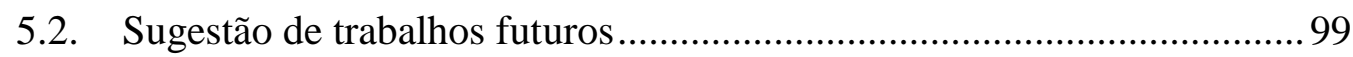

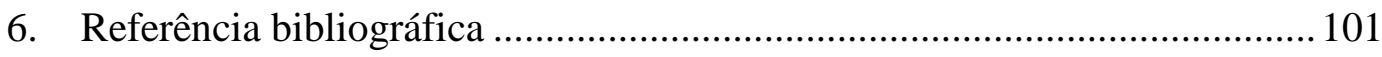

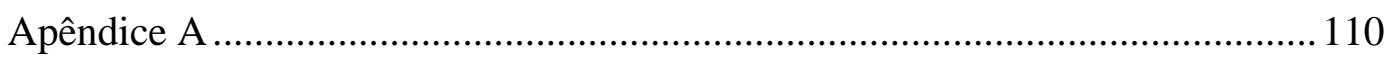

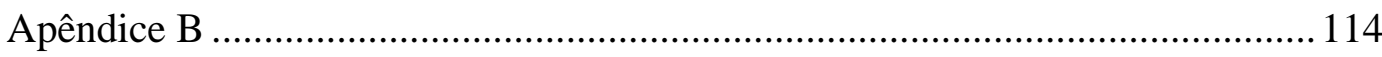




\section{Lista de Figuras}

Figura 1.1 - Objetivos da cimentação primária, adaptado de Smith [5]............... 18

Figura 2.1 - Tipos de deformações e suas origens, adaptado de Atrushi [9] .......21

Figura 2.2 - Estágios da fluência, adaptado de Findley et al. [46].......................2 29

Figura 2.3 - Ilustração do comportamento de um HPC submetido à

fluência a compressão e posterior recuperação, adaptado de Atrushi [9] 30

Figura 2.4 - Curva de deformação versus tempo, ilustrando os tipos de

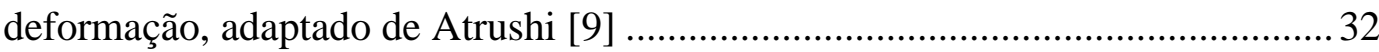

Figura 2.5 - Fatores que influenciam a fluência, adaptado de Byfors [49] ........... 33

Figura 3.1 - Organização do programa experimental .......................................... 41

Figura 3.2 - Fibras utilizadas: (a) fibra de curauá $12 \mathrm{~mm}$; (b) fibra de

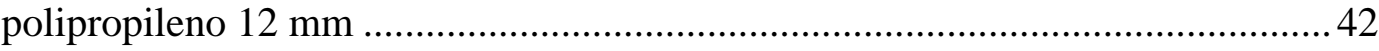

Figura 3.3 - Etapas do tratamento das fibras de curauá ....................................... 44

Figura 3.4 - Misturadores utilizados no preparo das amostras: (a)

Misturador 201, (b) Misturador 51 e (c) Misturador 1,51

Figura 3.5 - Ensaio de espalhamento: (a) molde cônico para o teste de espalhamento e (b) medição do espalhamento da pasta de cimento

Figura 3.6 - Aparelho de Vicat utilizado para determinação do tempo de pega

Figura 3.7 - Dimensões (em mm) do tubo corrugado de polietileno, adaptado de ASTM 1698 [86]

Figura 3.8 - Detalhe do ensaio de retração autógena: (a) corpos de prova ensaiados e (b) suporte com relógio comparador acoplado em uma das extremidades

Figura 3.9 - Disposição dos suportes utilizados para leitura da variação de comprimento do ensaio de retração autógena.

Figura 3.10 - Corpo de prova no tubo corrugado apoiado no suporte com

LVDT a esquerda para leitura da variação de comprimento 53

Figura 3.11 - Suporte do ensaio de retração autógena com relógio comparador localizado ao lado esquerdo

Figura 3.12 - Suporte do ensaio do tubo corrugado: hastes antes (a esquerda) e depois (a direita) de serem lixadas 
Figura 3.13 - Detalhe do tubo corrugado com o lado direito colado com araldite no suporte utilizado para o ensaio

Figura 3.15 - Etapas do ensaio de retração livre: (a) preparação dos moldes, (b) moldagem dos corpos de prova e (c) corpos de prova ensaiados

Figura 3.16 - Pórtico utilizado para leitura da variação de comprimento do ensaio de retração por secagem livre (a) e com corpo de prova (b) 57

Figura 3.17 - Barra de referência utilizada no ensaio de retração por secagem livre

Figura 3.18 - Descrição detalhada do molde do anel, adaptado de ASTM C1581 [89] 58

Figura 3.19 - Detalhe do ensaio de retração com restrição: (a) preparação do molde e (b) corpo de prova durante o ensaio (após retirada do anel de aço externo).

Figura 3.20 - Acompanhamento da abertura de fissura: (a) anel de pasta de cimento fissurado, (b) Microscópio Digital Portátil e (c) detalhe da fissura da pasta com adição de $1,2 \mathrm{~kg} / \mathrm{m}^{3}$ de curauá observada pelo microscópio

Figura 3.21 - Leitura das deformações do ensaio retração com restrição:

(a) aparelho da HBM para aquisição dos dados e (b) Interface do software Catman Easy 61

Figura 3.22 - Moldagem dos corpos de prova: (a) preparação dos moldes cilíndricos e (b) detalhe dos corpos de prova .....

Figura 3.23 - Ensaio de compressão: (a) equipamento utilizado e (b) detalhe do corpo de prova sendo ensaiado

Figura 3.24 - Valores médios de resistência máxima a compressão das misturas aos 3 dias de idade

Figura 3.25 - Disco de aço colocado entre os corpos de prova para o ensaio de fluência básica

Figura 3.26 - Ensaio de fluência: (a) Pórtico utilizado no ensaio de fluência básica a compressão, (b) disposição dos corpos de prova vedados com a rótula e a célula de carga e (c) visão geral do sistema.

Figura 3.27 - Ilustração da aplicação de carga nas roscas inferiores do pórtico 66 
Figura 3.28 - Chave de grifo utilizada para aplicação do torque 66

Figura 3.29 - Gráfico ilustrativo do sistema de aplicação de carga por meio de torque nas roscas da mesa do pórtico

Figura 3.30 - Leitura das deformações do ensaio de fluência: (a) Aparelho de aquisição de dados da National Instruments e (b) Interface do programa LabView 68

Figura 4.1 - Resumo das variáveis dos ensaios de retração autógena, retração por secagem com e sem restrição e de fluência básica a compressão

Figura 4.2 - Gráfico de retração autógena de pastas de cimento dos lotes I e II .70

Figura 4.3 - Gráfico de retração autógena da pasta de referência e de pastas reforçadas com curauá

Figura 4.4 - Gráfico de retração livre da pasta de referência e de pastas reforçadas com PP 73

Figura 4.5 - Gráfico de retração livre da pasta de referência e de pastas reforçadas com curauá .74

Figura 4.6 - Gráficos de retração por secagem livre separados por teores de fibras nas misturas: (a) $0,3 \mathrm{~kg} / \mathrm{m}^{3}$; (b) $1,2 \mathrm{~kg} / \mathrm{m}^{3}$; (c) $2,7 \mathrm{~kg} / \mathrm{m}^{3}$ 75

Figura 4.7 - Perda de massa dos corpos de prova de referência e reforçados com fibras de (a) polipropileno e (b) curauá 77

Figura 4.8 - Gráfico de retração livre por perda de massa da referência e de fibras de (a) polipropileno e (b) curauá 78

Figura 4.9 - Esquema representando as etapas para o cálculo da tensão no corpo de prova de anel, adaptado de Shah e Weiss [95]. (a) leitura da deformação pelos extensômetros; (b) pressão na interface anel de açopasta; (c) desenvolvimento da tensão residual na direção radial; (d) tensão máxima obtida no corpo de prova 79

Figura 4.10 - Gráficos típicos de (a) tensão e (b) deformação do ensaio de retração por secagem com restrição pelo método do anel

Figura 4.11 - Gráfico de retração com restrição da pasta de referência e de pastas reforçadas com PP. (a) Desenvolvimento da tensão no anel de pasta; (b) Desenvolvimento da deformação no anel de aço interno 
Figura 4.12 - Gráfico de retração com restrição da pasta de referência e de pastas reforçadas com curauá. (a) Desenvolvimento da tensão no anel de pasta; (b) Desenvolvimento da deformação no anel de aço interno

Figura 4.13 - Idade do corpo de prova no momento da fissura para cada mistura

Figura 4.14 - Gráficos de (a) tensão e (b) deformação do ensaios de retração por secagem com restrição em pastas com adição de $0,3 \mathrm{~kg} / \mathrm{m}^{3}$ de fibras 82

Figura 4.15 - Gráficos de (a) tensão e (b) deformação do ensaios de retração por secagem com restrição em pastas com adição de $1,2 \mathrm{~kg} / \mathrm{m}^{3}$ de fibras

Figura 4.16 - Gráficos de (a) tensão e (b) deformação do ensaios de retração por secagem com restrição em pastas com adição de $2,7 \mathrm{~kg} / \mathrm{m}^{3}$ de fibras 83

Figura 4.17 - Gráfico de deformação a partir da desmoldagem em função da raiz quadrada do tempo no mesmo período para mistura com adição de $2,7 \mathrm{~kg} / \mathrm{m}^{3}$ de polipropileno 85

Figura 4.18 - Gráficos da abertura de fissura em função do tempo (a) e do teor de fibras (b)

Figura 4.19 - Acompanhamento da abertura de fissuras: (a) fissura no anel de referência, (b) fissura no anel com $1,2 \mathrm{~kg} / \mathrm{m}^{3}$ de curauá e (c) detalhe da dispersão das fibras de curauá na fissura 88

Figura 4.20 - Deformação por fluência de pastas com cimento dos lotes I e II (a) com deformação elástica; (b) sem deformação elástica 90

Figura 4.21 - Esquema 2-D do C-S-H de (a) baixa densidade e (b) alta densidade, adaptado de [99]

Figura 4.22 - Gráfico de fluência da pasta de referência e de pastas reforçadas com PP (a) com deformação elástica; (b) sem deformação elástica 92

Figura 4.23 - Gráfico de fluência da pasta de referência e de pastas reforçadas com curauá (a) com deformação elástica; (b) sem deformação elástica

Figura 4.24 - Gráficos de fluência (a) com deformação elástica e (b) sem deformação elástica em pastas com adição de $0,3 \mathrm{~kg} / \mathrm{m}^{3}$ de fibras 
Figura 4.25 - Gráficos de fluência (a) com deformação elástica e (b) sem deformação elástica em pastas com adição de $1,2 \mathrm{~kg} / \mathrm{m}^{3}$ de fibras .94

Figura 4.26 - Gráficos de fluência (a) com deformação elástica e (b) sem deformação elástica em pastas com adição de $2,7 \mathrm{~kg} / \mathrm{m}^{3}$ de fibras

Figura 0.1 - Gráfico da deformação por retração livre dos corpos de prova de referência lote I

Figura 0.2 - Gráfico da deformação por retração livre dos corpos de prova de polipropileno $0,3 \mathrm{~kg} / \mathrm{m}^{3}$

Figura 0.3 - Gráfico da deformação por retração livre dos corpos de prova de polipropileno $1,2 \mathrm{~kg} / \mathrm{m}^{3}$

Figura 0.4 - Gráfico da deformação por retração livre dos corpos de prova de polipropileno $2,7 \mathrm{~kg} / \mathrm{m}^{3}$

Figura 0.5 - Gráfico da deformação por retração livre dos corpos de prova de curauá $0,3 \mathrm{~kg} / \mathrm{m}^{3}$

Figura 0.6 - Gráfico da deformação por retração livre dos corpos de prova de curauá $1,2 \mathrm{~kg} / \mathrm{m}^{3}$

Figura 0.7 - Gráfico da deformação por retração livre dos corpos de prova de curauá $2,7 \mathrm{~kg} / \mathrm{m}^{3}$

Figura 0.8 - Gráficos dos ensaios de retração com restrição:

(a) Desenvolvimento da deformação do anel de referência lote II;

(b) Deformação média versus raiz quadrada do tempo

Figura 0.9 - Gráficos dos ensaios de retração com restrição:

(a) Desenvolvimento da deformação do anel de PP0,3 kg/m³;

(b) Deformação média versus raiz quadrada do tempo 118

Figura 0.10 - Gráficos dos ensaios de retração com restrição:

(a) Desenvolvimento da deformação do anel de PP1,2 kg/m³;

(b) Deformação média versus raiz quadrada do tempo

Figura 0.11 - Gráficos dos ensaios de retração com restrição:

(a) Desenvolvimento da deformação do anel de PP2,7 kg/m³;

(b) Deformação média versus raiz quadrada do tempo

Figura 0.12 - Gráficos dos ensaios de retração com restrição:

(a) Desenvolvimento da deformação do anel de curauá $0,3 \mathrm{~kg} / \mathrm{m}^{3}$;

(b) Deformação média versus raiz quadrada do tempo 120 
Figura 0.13 - Gráficos dos ensaios de retração com restrição:

(a) Desenvolvimento da deformação do anel de curauá $1,2 \mathrm{~kg} / \mathrm{m}^{3}$;

(b) Deformação média versus raiz quadrada do tempo 120

Figura 0.14 - Gráficos dos ensaios de retração com restrição:

(a) Desenvolvimento da deformação do anel de curauá $2,7 \mathrm{~kg} / \mathrm{m}^{3}$;

(b) Deformação média versus raiz quadrada do tempo

Figura 0.15 - Deformação por fluência básica: (a) deformação total e

(b) sem deformação elástica dos corpos de prova de referência com cimento lote I

Figura 0.16 - Deformação por fluência básica: (a) deformação total e

(b) sem deformação elástica dos corpos de prova de referência com cimento lote II

Figura 0.17 - Deformação por fluência básica: (a) deformação total

e (b) sem deformação elástica dos corpos de prova com cimento dos

lotes I e II

Figura 0.18 - Deformação por fluência básica: (a) deformação total

e (b) sem deformação elástica dos corpos de prova com adição de

$0,3 \mathrm{~kg} / \mathrm{m}^{3}$ de PP

Figura 0.19 - Deformação por fluência básica: (a) deformação total

e (b) sem deformação elástica dos corpos de prova com adição de

$1,2 \mathrm{~kg} / \mathrm{m}^{3}$ de PP

Figura 0.20 - Deformação por fluência básica: (a) deformação total

e (b) sem deformação elástica dos corpos de prova com adição de

$2,7 \mathrm{~kg} / \mathrm{m}^{3}$ de PP

Figura 0.21 - Deformação por fluência básica: (a) deformação total

e (b) sem deformação elástica dos corpos de prova com adição de

$0,3 \mathrm{~kg} / \mathrm{m}^{3}$ de curauá

Figura 0.22- Deformação por fluência básica: (a) deformação total

e (b) sem deformação elástica dos corpos de prova com adição de

$1,2 \mathrm{~kg} / \mathrm{m}^{3}$ de curauá

Figura 0.23 - Deformação por fluência básica: (a) deformação total

e (b) sem deformação elástica dos corpos de prova com adição de

$2,7 \mathrm{~kg} / \mathrm{m}^{3}$ de curauá 


\section{Lista de Tabelas}

Tabela 2.1 - Mecanismos de deformação, diagramas, tensão e deformação, adaptado de Mehta e Monteiro [48]

Tabela 2.2 - Classificação das deformações reversíveis e irreversíveis,

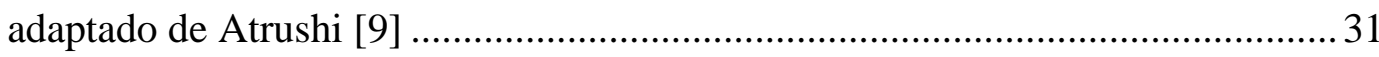

Tabela 3.1 - Propriedades dos cimentos classe G............................................. 42

Tabela 3.2 - Características das fibras de curauá e polipropileno........................ 43

Tabela 3.3 - Tempo das etapas de mistura das pastas por tipo de

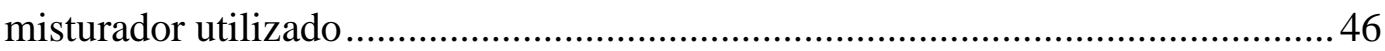

Tabela 3.4 - Descrição das legendas utilizadas na pesquisa ............................... 47

Tabela 3.5 - Resultados dos testes de espalhamento das pastas de cimento com e sem fibras 49

Tabela 3.6 - Valores médios de resistência à compressão aos 3 dias de idade das pastas de cimento com e sem reforço fibroso 64

Tabela 4.1 - Valores dos ensaios de retração autógena......................................... 72

Tabela 4.2 - Valores médios dos ensaios de retração livre .................................. 76

Tabela 4.3 - Valores obtidos pelo ensaio de retração com restrição

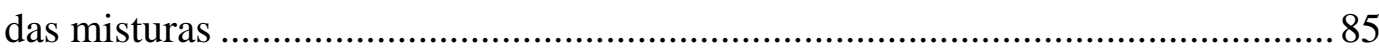

Tabela 4.4 - Potencial de fissuração, adaptado de See et al. [96] ........................ 86

Tabela 4.5 - Valores médios dos ensaios de retração por secagem com restrição 89

Tabela 4.6 - Valores de carga máxima resistida a compressão e carga aplicada no ensaio de fluência 96

Tabela 4.7 - Valores de deformação total e por fluência obtidos pelo ensaio de fluência a compressão. 
"Talvez não tenha conseguido fazer o melhor, mas lutei para que o melhor fosse feito. Não sou o que deveria ser, mas Graças a Deus, não sou o que era antes."

Martin Luther King 


\section{Introdução}

\subsection{Motivação}

Materiais cimentícios, tais como concretos, argamassas e pastas, são afetados pelos fenômenos de retração autógena, por secagem livre e com restrição, e fluência a compressão estudados nesta pesquisa. Na pasta de cimento encontra-se a principal origem da deformação desses materiais susceptíveis a retração e fluência [1].

Em materiais com elevada quantidade de pasta de cimento, tais como grautes, o estudo da retração e fluência é importante. Os grautes são utilizados para reparos e reforços de estruturas de concreto tanto em ambientes externos quanto submersos, no preenchimento de bicheiras (vazios) da concretagem e colunas de alvenaria estrutural, na fixação de pré-moldados ou de trilhos de trem ou metrô, e ancoragem e chumbamento de tirantes e fixadores. Devem ser fluidos, permitindo o bombeamento, ter pouca ou nenhuma retração e não exibir segregação e exsudação excessiva [2].

A pasta de cimento é o principal componente utilizado nos grautes, que contêm até cinco vezes mais cimento do que o concreto comum. Por isso, é importante o estudo da retração. Este efeito pode causar o desprendimento do graute do substrato em que ele foi adicionado, provocando uma descontinuidade na transferência de tensões [2].

Nos dias atuais, a pasta de cimento tem sido utilizada na construção de poços de petróleo. A descoberta recente de petróleo em águas profundas, localizada no pré-sal, a quilômetros de distância da superfície em alto mar trouxe novos desafios para a extração de petróleo desta região. A produção de petróleo oriundo do pré-sal aumentou de 41 mil barris por dia em 2010 para 1 milhão em 2016. Esse crescimento na produção de quase 24 vezes é espelho de todo investimento no desenvolvimento de novas tecnologias para a extração de petróleo destas regiões, que são muito mais produtivas que as regiões do pós-sal [3].

Com a construção de poços de petróleo ainda mais profundos, o desenvolvimento de pastas cimentícias ganhou importância. A etapa cimentação 
está presente na fase de completação durante a construção de poços de petróleo, e pode ser dividida entre cimentação primária e "recimentação". A cimentação primária tem como objetivo principal fornecer, no poço de petróleo, isolamento completo e permanente das zonas permeáveis localizadas atrás da coluna de revestimento [4]. Este processo consiste em colocar o cimento no espaço anular entre a coluna de revestimento e as formações rochosas a fim de se obter uma vedação hidráulica entre o revestimento e o cimento e entre o cimento e as formações rochosas. A Figura 1.1 ilustra os objetivos da cimentação primária, ressaltando o isolamento das zonas. Além da vedação hidráulica, a adição da pasta de cimento no espaço anular elimina canais de fluidos no cimento, previne a corrosão da coluna de revestimento e mantém a estabilidade mecânica do poço. Sem o isolamento completo das zonas, pode haver perda de reservas de petróleo ou redução do potencial de produção do poço [5].

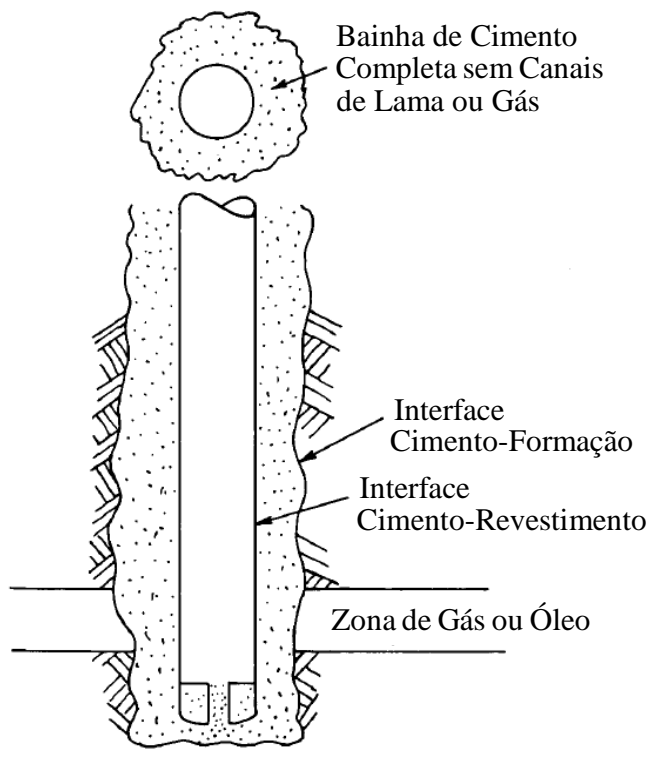

Figura 1.1 - Objetivos da cimentação primária, adaptado de Smith [5]

A qualidade da cimentação é o fator que mais influencia o isolamento zonal. Dessa forma, a cimentação de um poço deve ser de importância crítica para todos os operadores. A "recimentação" se faz necessária quando há problemas com a cimentação primária ou em casos de abandono do poço, quando o mesmo não será mais explorado [4].

A norma API 10B [6] para testes em cimentos para poços classifica os cimentos Portland de acordo com sua resistência ao sulfato, sendo: comum (O), 
resistência moderada ao sulfato (MSR) e alta resistência ao sulfato (HSR). Oito classes de cimento Portland para poços de petróleo são definidas pela API, e a nomenclatura varia de $\mathrm{A}$ a $\mathrm{H}$. No entanto, as classes $\mathrm{G}$ e H são normalmente as mais usadas para cimentação de poços nos dias atuais, por não conterem nenhum aditivo além do sulfato de cálcio e água no clínquer [7]. Esta pesquisa utilizou cimento Classe G HSR para a realização de todos os ensaios em pastas.

\subsection{Objetivos}

O presente trabalho tem como objetivo analisar a influência das fibras de curauá e polipropileno na retração autógena, retração por secagem com e sem restrição e na fluência básica a compressão. Uma análise comparativa foi feita entre as pastas de cimento de referência e reforçadas com três diferentes teores de fibras no intuito de observar o efeito da adição dessas fibras no comportamento das pastas nas primeiras idades.

\subsection{Organização do Trabalho}

O presente trabalho está organizado em seis capítulos da seguinte maneira:

O capítulo 1 contém a introdução, onde se contextualiza o assunto do trabalho e se apresenta a motivação para o desenvolvimento da pesquisa.

O capítulo 2 apresenta a revisão bibliográfica, onde são apresentados breve resumos conceituais e resultados experimentais de fatores que influenciam a retração e a fluência encontrados na literatura por outros autores.

O capítulo 3 descreve o programa experimental realizado na presente pesquisa e a metodologia de ensaio que foram realizados. São apresentados as características dos materiais empregados na mistura da pasta de cimento e os equipamentos necessários desde a moldagem até o ensaio efetivamente. Este capítulo também apresenta a metodologia para o desenvolvimento dos ensaios de retração autógena e fluência, implementados no laboratório por meio desta pesquisa.

O capítulo 4 evidencia os resultados obtidos experimentalmente e apresenta uma análise desses resultados de acordo com o que é apresentado na literatura sobre a influência de fibras naturais e sintéticas nas retrações autógena e por secagem com e sem restrição, e na fluência básica. 
Por fim, o capítulo 5 apresenta as conclusões finais da pesquisa e sugestões de futuros trabalhos necessários para melhor entender o comportamento desses materiais sob as condições estudadas. 


\section{Revisão Bibliográfica}

\subsection{Tipos de Deformação}

O concreto, a pasta de cimento ou a argamassa são materiais que se deformam, e essa deformação não necessariamente ocorre através da aplicação de forças externas. A Figura 2.1 mostra os diferentes tipos de deformação estudadas neste trabalho que podem ocorrer em materiais cimentícios. Dentre as deformações causadas por forças internas está a deformação por retração, e as causadas por forças externas estão as deformações instantânea e por fluência. A deformação instantânea ocorre no momento de aplicação da carga e é independe do tempo. Já a deformação por fluência depende do tempo de exposição do material a essa carga [8].

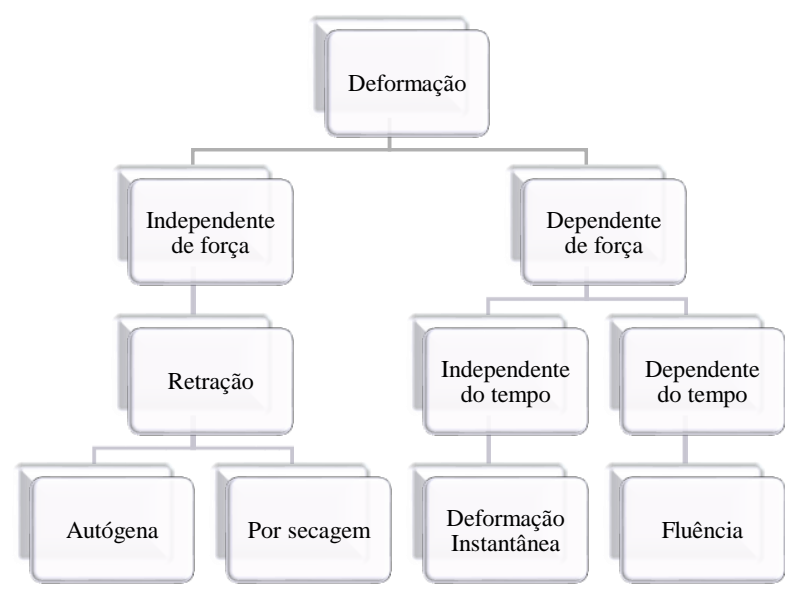

Figura 2.1 - Tipos de deformações e suas origens, adaptado de Atrushi [9]

\subsection{Retração}

\subsubsection{Mecanismos da retração}

A retração é um fenômeno que ocorre nas pastas de cimento devido à perda de volume da mistura sem que haja nenhuma força externa, e pode ocorrer por diferentes causas. A retração e a dilatação são deformações independentes de tensão, que ocorrem com o tempo principalmente devido ao movimento da umidade do ou para o concreto, ou por consumo de água interna pela hidratação do cimento 
[9]. As retrações mais comuns relacionadas à pasta de cimento são a retração plástica, química, autógena e por secagem.

A retração plástica ocorre nas primeiras horas após a moldagem. Pode ser definida como sendo a redução de volume do concreto fresco, ainda na fase plástica, devido à perda de água livre para o meio externo. A retração plástica ocorre quando a taxa de evaporação da água da mistura excede a taxa do efeito de exsudação [10, 11]. Sua magnitude é influenciada pela temperatura, umidade relativa do ambiente e velocidade do vento [9]. Quanto maior o teor de cimento, mais fino for o cimento e menor o fator água/cimento, maior a retração plástica [9].

A retração química é definida pela ASTM C1608 [12] como a variação do volume absoluto (interno) devido à hidratação do cimento. Ela ocorre porque os produtos de reação na hidratação do cimento têm um volume menor do que seus reagentes.

A retração autógena ocorre depois do tempo de pega da pasta de cimento. $\mathrm{Na}$ reação química entre cimento e água, toda a água dos poros é consumida, esvaziando os poros na pasta e consequentemente produzindo uma queda da umidade relativa interna (auto dessecação). Esse processo leva ao surgimento de tensões capilares nos poros, que induzem uma contração do volume externo, denominada retração autógena [13].

A retração autógena no concreto é de menor valor do que da pasta de cimento, porque além da restrição causada pelo esqueleto da pasta de cimento já hidratado, o agregado presente no concreto fornece uma restrição extra [11].

Existe, na literatura, certa divergência na determinação do significado desses termos. Jensen e Hansen [14] por exemplo, definem retração por auto dessecação como sendo uma deformação autógena causada pela retração química de um material cimentício após o tempo de pega e define deformação autógena como sendo a deformação total de um sistema de material cimentício isotérmico e fechado não submetido a forças externas. Bentz et al. [15] se referem ao efeito da auto dessecação como sendo retração autógena. O presente trabalho irá considerar retração autógena como sendo a retração causada pelo efeito de auto dessecação, definida acima por Zhang et al. [13]. No entanto, não irá separar os efeitos causados pela retração química, uma vez que esta não está no escopo desta pesquisa.

A retração por secagem é a perda de umidade interna da pasta de cimento ou do concreto no estado endurecido quando exposto a um ambiente de menor 
umidade. A evaporação da água na superfície do material faz com que o material retraia, causando deformações [16]. Quando a retração por secagem é restrita, desenvolvem-se tensões de tração no concreto. Quando essas tensões são maiores que a resistência do concreto à tração, ocorrem as fissuras. O estudo da fissuração no concreto devido à retração é de grande importância, uma vez que fissuras facilitam a entrada de substâncias nocivas e reduzem a capacidade de carga do concreto [17].

Como é dificil se determinar a retração por secagem excluindo os efeitos da retração autógena, muitos autores estudam os efeitos da retração total (autógena e por secagem) $[13,18,19]$.

\subsubsection{Fatores que influenciam a retração}

A retração é influenciada por diversos fatores como fator água/cimento, adição de materiais pozolânicos - como sílica ativa, escórias, cinza volante e metacaolim, o tipo de cimento - finura, composição química e mineral, adição de fibras de diversas origens - sintéticas e naturais [20-24].

\subsubsection{Influência da finura e do tipo de cimento na retração}

Observações a respeito da influência da composição e da finura do cimento na retração autógena são divergentes na literatura. Tazawa e Miyazawa [21], Jensen [25] e Saje [26], estudaram o efeito da composição do cimento na retração autógena. Tazawa e Miyazawa [21] e Jensen [25] observaram que os minerais $\mathrm{C}_{3} \mathrm{~S}$ e $\mathrm{C}_{2} \mathrm{~S}$ não influenciam o desenvolvimento da retração autógena.

No entanto, os autores encontraram resultados distintos quanto à influência de outros minerais presentes do cimento. Tazawa e Miyazawa [21] observaram que o teor de $\mathrm{C}_{3} \mathrm{~A}$ e $\mathrm{C}_{4} \mathrm{AF}$ influencia significativamente o desenvolvimento da retração autógena, e concluíram que quanto maior o teor desses componentes minerais presentes no cimento, maior será o valor da retração.

De maneira oposta, Jensen [25] observou que a adição de $\mathrm{C}_{3} \mathrm{~A}$ e gesso reduziu significativamente a retração autógena e a umidade relativa interna da amostra, gerando, inclusive, uma expansão nas primeiras horas. Essa expansão possivelmente se deve à formação da etringita, produto da reação de hidratação do cimento [25, 27]. 
$\mathrm{O}$ aumento no teor de $\mathrm{C}_{3} \mathrm{~A}$ aumenta a retração química e melhora a sensibilidade da mistura à umidade relativa, ou seja, permite a hidratação do cimento mesmo com umidade relativa reduzida. Considerando separadamente esses efeitos em consequência do aumento no teor de $\mathrm{C}_{3} \mathrm{~A}$, a deformação autógena deveria aumentar [25]. No entanto, segundo Jensen [25], a estrutura dos poros possivelmente tem um efeito predominante na deformação autógena, o que poderia justificar a redução da deformação encontrada por ele com o aumento de $\mathrm{C}_{3} \mathrm{~A}$. O autor afirma ainda que a redução na deformação autógena pode ter influência indireta da hidratação da sílica ativa adicionada na mistura.

Estudos mais recentes realizados por Saje [26] demonstram que o teor de $\mathrm{C}_{3} \mathrm{~S}$ e $\mathrm{C}_{2} \mathrm{~S}$ influenciam a retração autógena, divergindo com o que foi afirmado anteriormente por Tazawa e Miyazawa [21] e Jensen [25]. O autor observou uma redução de $87 \%$ na retração autógena nas primeiras 48 horas para pastas com maior teor de $\mathrm{C}_{2} \mathrm{~S}$. Isso ocorreu devido a um menor consumo de água na hidratação do $\mathrm{C}_{2} \mathrm{~S}$, que resulta em menor auto dessecação e menor tensão capilar nos poros da pasta de cimento.

Dessa forma, os resultados obtidos por esses autores são, de forma geral, inconclusivos. A complexidade no entendimento do papel dos minerais do cimento na retração autógena se justifica pelo fato de que diversos outros fatores como teor de gesso, cal livre, álcalis e a própria adição de sílica ativa também influenciam diretamente a deformação autógena [25].

No que se refere à finura do cimento utilizado nas pastas, pode-se afirmar que quanto mais fino o cimento, maior a deformação autógena associada a ele [20, 25 28]. Além disso, a taxa de hidratação da pasta depende da finura do cimento, uma vez que a hidratação começa na superfície das partículas de cimento. Segundo Neville [11], o cimento mais fino leva a uma maior retração e maior propensão à fissuração, apesar de ter menor efeito de exsudação.

Bentz et al. [29] afirmam que a tensão capilar é significantemente sensível à redução da umidade relativa interna e é predominante para determinação da retração autógena. Por isso, embora a quantidade de poros cheios de água seja menor devido a uma maior taxa de hidratação do cimento fino (que consequentemente aumenta a retração química e a quantidade de poros vazios), o uso do cimento fino resulta em uma maior redução da umidade relativa interna, resultando em uma maior tensão capilar, que aumenta a retração autógena. 
Bennett e Loat [30] investigaram a influência da finura do cimento na retração por secagem com e sem restrição de concretos. Os autores observaram que nas primeiras 24 horas as amostras contendo cimento mais fino apresentaram maiores valores de retração, provavelmente, segundo o autor, devido a uma maior taxa de hidratação. A longo prazo (500 dias), a finura não aparentou influenciar de forma significativa a retração livre. Ao mesmo tempo, o cimento mais fino apresentou uma tendência a fissurar mais cedo quando comparado ao cimento mais grosso.

\subsubsection{Influência do fator água/cimento}

A influência do fator água/cimento $(\mathrm{a} / \mathrm{c})$ nas retrações já foi estudado por diversos autores. Os resultados encontrados na literatura mostram que o aumento do fator a/c reduz a retração autógena de pastas de cimento. Gao et al. [31] estudaram três fatores de água/cimento distintos $(0,26,0,30$ e 0,40$)$ para pastas nas primeiras 24 horas de idade e observaram que a retração autógena diminuiu com o aumento do fator a/c. Isso também foi encontrado por Tazawa e Miyazawa [20] para pastas com fatores a/c de 0,23, 0,30 e 0,40, e por Baroghel-Bouny [32] para pastas com fator a/c variando entre 0,25 e 0,60 . Bentz et al. [33] avaliaram o comportamento de argamassas com fator a/c variando de entre 0,325 e 0,425 na retração autógena e observaram comportamento similar. Zhang et al. [13] e Zhutovsky e Kovler [34] também observaram uma redução na retração autógena de concretos com o aumento do fator a/c tanto em idades iniciais quanto avançadas.

Baroghel-Bouny [32] avaliou o comportamento de pastas de cimento com fator a/c variando entre 0,25 e 0,60 na retração por secagem e observou que a retração livre diminuiu com a redução do fator a/c de 0,60 para 0,25 . Zhang et al. [13] avaliaram os efeitos da variação do fator a/c na retração total (retração por secagem e parte da retração autógena). A retração total diminuiu com a redução do fator a/c. Segundo o autor, essa redução ocorreu devido a uma maior perda de água para o meio ambiente quando o fator a/c foi aumentado. Este aumento teria aumentado de forma expressiva os valores de retração por secagem. Ao contrário de Baroghel-Bouny [32] e Zhang et al [13], Zhutovsky e Kovler [34] observaram que a retração livre de concretos diminuiu com o aumento do fator a/c de 0,21 para 0,33 . 


\subsubsection{Influência de fibras na retração}

Em geral, fibras são adicionadas ao concreto com o intuito de melhorar o controle das fissuras e modificar o comportamento da matriz após a fissuração. A infinidade de tipos, tamanhos e variações na geometria das fibras são tantas quanto suas possibilidades de aplicação em compósitos reforçados com fibras [35].

Um dos benefícios do concreto reforçado com fibras é a sua boa capacidade de absorção de energia [36], e por isso o uso de fibras no controle dos diversos tipos de retração em pasta de cimento e concreto vem sendo estudado por muitos autores. Yousefieh [36], Daneti e Wee [37], Aly e Sanjayan [38], Xie et al. [39], Zhang e Li [40] e Saje [18, 19] estudaram a influência da adição de fibra de polipropileno nas retrações autógena e por secagem com e sem restrição.

A adição de fibras curtas $(12-20 \mathrm{~mm})$ de polipropileno aleatoriamente distribuída em concreto ou pasta de cimento previne o surgimento e o desenvolvimento das fissuras devido à retração por secagem com restrição de forma significativa [36-39]. Já a influência dessas fibras na retração por secagem sem restrição possui divergências na literatura. Alguns autores afirmam que a adição de fibras de polipropileno tem nenhuma ou pouca redução na retração [36-38]. Outros autores afirmam que a redução na retração por secagem sem restrição é significativa, e que aumenta com o aumento do teor das fibras [39, 40].

A influência das fibras de polipropileno com comprimento de $12 \mathrm{~mm}$ na retração autógena foi estudada por Saje et al. [18, 19]. Em seus estudos, os autores avaliaram o desempenho dessas fibras secas e previamente umedecidas, e concluiu que a adição de fibras de polipropileno reduziu a retração autógena, sendo essa redução ainda mais significativa para misturas com fibras umedecidas. Além disso, os autores observaram que a redução da retração autógena foi diretamente proporcional ao aumento do teor de fibras previamente umedecidas na mistura. Essas fibras, além de terem aumentado o teor de água na mistura, serviram de reservatório de água, o que resultou em forças capilares menores no concreto relativamente fresco, e consequentemente valores menores de retração autógena principalmente durante as primeiras 24 horas de idade [19].

Em contrapartida, a retração por secagem de misturas contendo fibras umedecidas é maior do que misturas com fibras secas. Isso é justificado pelo fato das misturas contendo fibras umedecidas terem um maior teor de água disponível 
para evaporar durante a secagem. Foi observado também que até os 14 dias de idade, a retração por secagem livre foi maior para o maior teor de fibras, mas ainda assim menor que a mistura de referência, sem fibras.

Existem poucos estudos sobre a influência de fibras naturais nas retrações e nenhum sobre a influência de fibras de curauá. Buch [41], Kawashima e Shah [42] e Rapoport e Shah [43] estudaram o efeito da adição de fibras de celulose nas retrações plástica, autógena e por secagem, respectivamente. Foi observado que a adição de fibras posterga o aparecimento e reduz significantemente a abertura das fissuras na retração plástica [41]. Além disso, reduz cerca de $32 \%$ o valor da retração autógena para adição de $2 \%$ de fibra aos sete dias de idade [42]. O uso de fibras de celulose também reduz consideravelmente a abertura de fissura em argamassas (37\% aos 14 dias de idade), mesmo para pequenos teores de fibras $(0,14 \%)[43]$.

A redução da abertura de fissuras e o adiamento no aparecimento delas devido à retração por secagem com restrição também foi observada por [42] para concretos com fibras de celulose. $\mathrm{O}$ autor também concluiu que a adição dessas fibras não altera o valor da retração por secagem livre. Além disso, as fibras de celulose foram ineficientes para uso apenas como agente de cura interna, uma vez que possuem baixa capacidade de absorção de água (seu peso após saturada por 24 horas é cerca de 1,2 vezes maior). Seria necessário um alto teor dessas fibras (cerca de 4,5\% pela massa do cimento para mistura com a/c de 0,28 ) para reduzir substancialmente a retração autógena, diminuindo consideravelmente a trabalhabilidade da mistura.

Sales [44] avaliou a influência de polpa de bambu e polpa de sisal nas retrações por secagem livre e com restrição. A autora observou que durante as primeiras horas de ensaio da retração livre, a adição de fibras não alterou o comportamento de deformação do compósito. No entanto, a partir de 12 horas de ensaio os compósitos com polpa passaram a apresentar maior deformação por retração. $\mathrm{O}$ aumento da retração foi proporcional ao aumento no teor de polpa, de 10 para $14 \%$ da massa do aglomerante. Para um mesmo teor (8\%), compósitos com polpa de sisal apresentaram maiores valores de retração quando comparados aos compósitos com polpa de bambu, chegando a ser 16,7\% maior em um ano de ensaio. A adição em pasta de cimento de polpa de bambu em 8 e 14\% da massa de cimento restringiu o aparecimento de fissuras, enquanto amostras sem a adição apresentaram duas microfissuras. 
Toledo Filho et al. [45] observaram que a adição de fibras de $25 \mathrm{~mm}$ de comprimento de sisal e coco aumentou a retração por secagem livre independentemente do método de cura (os autores testaram 3 métodos diferentes). Os autores observaram também que quanto maior foi o teor de fibras adicionadas na argamassa, maior foi o resultado da retração. Isso pode ser explicado pela natureza porosa das fibras naturais, que criam caminhos de umidade na matriz na escala da microestrutura, além de aumentar a porosidade do compósito. O tipo de fibra aparentou influenciar os valores de retração. A adição em argamassa de 3\% de fibras de sisal apresentou deformações 8,2\% maiores aos 320 dias de ensaio quando comparadas à compósitos com o mesmo teor de fibras de coco. Isso pode ser explicado pela maior absorção de água e pela superfície menos lisa da fibra de sisal se comparada à fibra de coco.

\subsection{Fluência}

\subsubsection{Mecanismos da fluência}

Fluência pode ser definida como um aumento gradual e contínuo da deformação sob uma carga constante $[11,46]$. Ela pode ser dividida em três estágios: primário, secundário e terciário. Esses estágios são representados no gráfico da Figura 2.2. No estágio primário a fluência ocorre a uma taxa decrescente. No segundo, a taxa permanece quase constante, e no terceiro estágio a taxa é crescente, terminando em fratura [46]. 


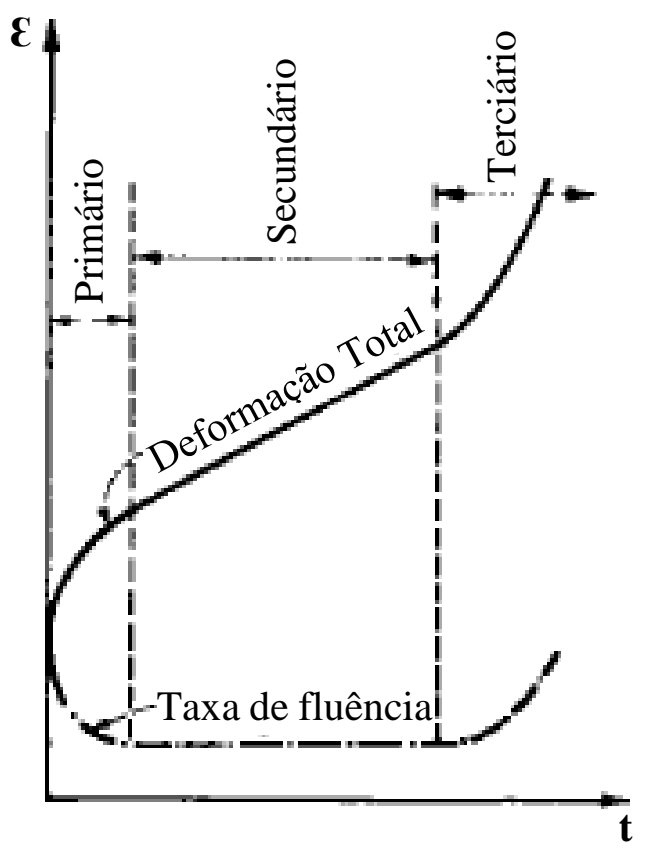

Figura 2.2 - Estágios da fluência, adaptado de Findley et al. [46]

A deformação exibida durante a aplicação de carga é essencialmente deformação elástica com um pequeno componente de deformação inelástica (permanente), e define o módulo de elasticidade estático na idade de aplicação da carga [9]. No entanto, sob condições normais de carregamento, a leitura da deformação instantânea depende da velocidade de aplicação da carga e inclui, portanto, não apenas a deformação elástica, mas também alguma deformação devido à fluência. Diferenciar a deformação elástica da deformação por fluência em idades jovens é difícil, porque nem sempre o módulo de elasticidade é medido em diferentes idades [11].

Dessa forma, Atrushi [9] sugere que a deformação que ocorre durante a aplicação de carga seja definida como deformação elástica e a posterior como deformação por fluência. Em outras palavras, a deformação por fluência é frequentemente considerada como o aumento da deformação acima da deformação inicial, como ilustra a Figura 2.3, e a deformação total é a soma da deformação instantânea e deformação por fluência [46]. Essa consideração, apesar de menos correta, não introduz nenhum erro grave e se torna mais conveniente de ser usada uma vez que, na prática, o que importa é a deformação total induzida pela aplicação de carga. 


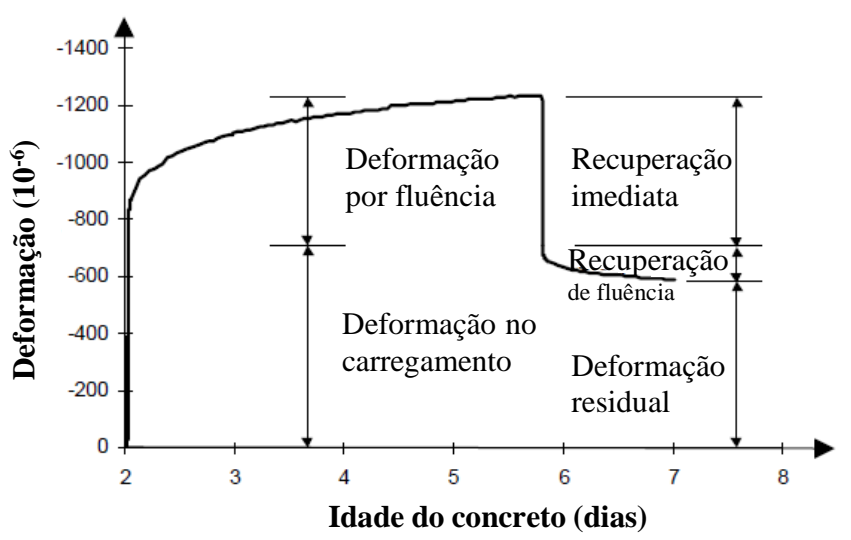

Figura 2.3 - Ilustração do comportamento de um HPC submetido à fluência a compressão e posterior recuperação, adaptado de Atrushi [9]

Além da deformação elástica e deformação por fluência, existe também a deformação devido à retração. Portanto, de forma simplificada, a deformação por fluência é normalmente calculada como a diferença da deformação no tempo total da amostra carregada e a deformação por retração de uma amostra similar, durante o mesmo período de tempo e sob as mesmas condições de armazenamento. Apesar de esta simplificação ser conveniente, a fluência e a retração não são fenômenos independentes no qual o princípio da superposição pode ser aplicado, e, de fato, o efeito da retração na fluência aumenta a magnitude da fluência. O estudo desses dois fenômenos juntos é conveniente, uma vez que muitas estruturas têm esses efeitos simultaneamente [11].

A fluência está sempre relacionada com algum tipo de retração. Quando o ensaio de fluência é feito em condições onde não há troca de umidade entre o concreto e o meio ambiente, e o transporte de água ocorre exclusivamente dentro do material, o valor de deformação calculado é referente à fluência básica [47]. A deformação adicional causada pela perda de água para o meio externo é chamada de fluência por secagem $[11,48]$. Essa distinção está ilustrada na Tabela 2.1. 
Tabela 2.1 - Mecanismos de deformação, diagramas, tensão e deformação, adaptado de Mehta e Monteiro [48]

\begin{tabular}{|c|c|c|c|c|}
\hline Mecanismo & Diagrama & Deformação vs. Tempo & Tensão vs. Tempo & Comentários \\
\hline Fluência Básica & $\ldots ., \sigma_{0}$ & $\underset{\text { Tempo }}{\stackrel{\text { Elástica }}{\longrightarrow}}$ & $\sigma_{0}^{\text {Tensão }}$ & $\begin{array}{l}\text { Nenhum movimento de umidade } \\
\text { entre o concreto e o ambiente } \\
\text { (sem retração por secagem) } \\
\text { Tensão constante ao longo do } \\
\text { tempo }\end{array}$ \\
\hline $\begin{array}{c}\text { Retração por } \\
\text { Secagem } \\
\text { (sem restrição) }\end{array}$ & $R H<100 \%$ & $\underset{\text { Tempo }}{\longrightarrow}$ & $\int^{\text {Tensão }}$ & $\begin{array}{l}\text { Livre para se mover } \\
\text { Não são geradas tensões }\end{array}$ \\
\hline $\begin{array}{c}\text { Retração por } \\
\text { Secagem } \\
\text { (com restrição) }\end{array}$ & $\ell_{0}$ & Deformaçăo & $\underset{\text { Tempo }}{\stackrel{\text { Tensão }}{\longrightarrow}}$ & $\begin{array}{l}\text { Desenvolvimento de tensão de } \\
\text { tração }\end{array}$ \\
\hline $\begin{array}{l}\text { Fluência } \\
+ \\
\text { Retração por } \\
\text { Secagem }\end{array}$ & 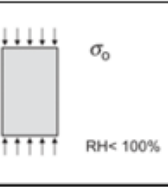 & \begin{tabular}{|l|l|} 
Deformaçäo & $\begin{array}{l}\text { Fluência por } \\
\text { secagem }\end{array}$ \\
Elástica & Fluência básica \\
& Tempo \\
\end{tabular} & $\underset{\text { Tempo }}{\vec{\longrightarrow}}$ & $\begin{array}{l}\text { Deformação total não é a soma } \\
\text { da elástica, fluência básica e } \\
\text { retração por secagem. } \\
\text { Fluência devido a fluência por } \\
\text { secagem deve ser incluída }\end{array}$ \\
\hline
\end{tabular}

As deformações dependentes do tempo podem ser classificadas em reversíveis e irreversíveis (ou permanentes) [9, 11, 49]. As deformações reversíveis são as deformações elástica instantânea, $\varepsilon_{\mathrm{el}}$ (independente do tempo), e elástica atrasada, $\varepsilon_{e l, d}$ (dependente do tempo), e as irreversíveis são as inelásticas instantâneas de natureza plástica, $\varepsilon_{\text {nel }}$ (independente do tempo) e a inelástica atrasada de natureza viscosa, $\varepsilon_{\text {nel,d }}$ (dependente do tempo) [9]. A Tabela 2.2 e a Figura 2.4 resumem essas deformações de forma simplificada.

Tabela 2.2 - Classificação das deformações reversíveis e irreversíveis, adaptado de Atrushi [9]

\begin{tabular}{|c|c|c|c|}
\hline \multirow{2}{*}{ Deformação } & \multicolumn{2}{|c|}{ Dependente da carga } & \multirow{2}{*}{ Independente da carga } \\
\hline & Instantânea & Dependente de tempo & \\
\hline Reversível & Elástica (عel) & Elástica atrasada $(\varepsilon e l, d)$ & \multirow{2}{*}{$\begin{array}{l}\text { Dilatação térmica* e } \\
\text { Retração ou expansão* }\end{array}$} \\
\hline Irreversível & Inelástica (عnel) & Inelástica atrasada $(\varepsilon n e l, d)$ & \\
\hline
\end{tabular}

*Tanto a dilatação térmica como a retração (ou expansão) tem componentes reversíveis e irreversíveis. 

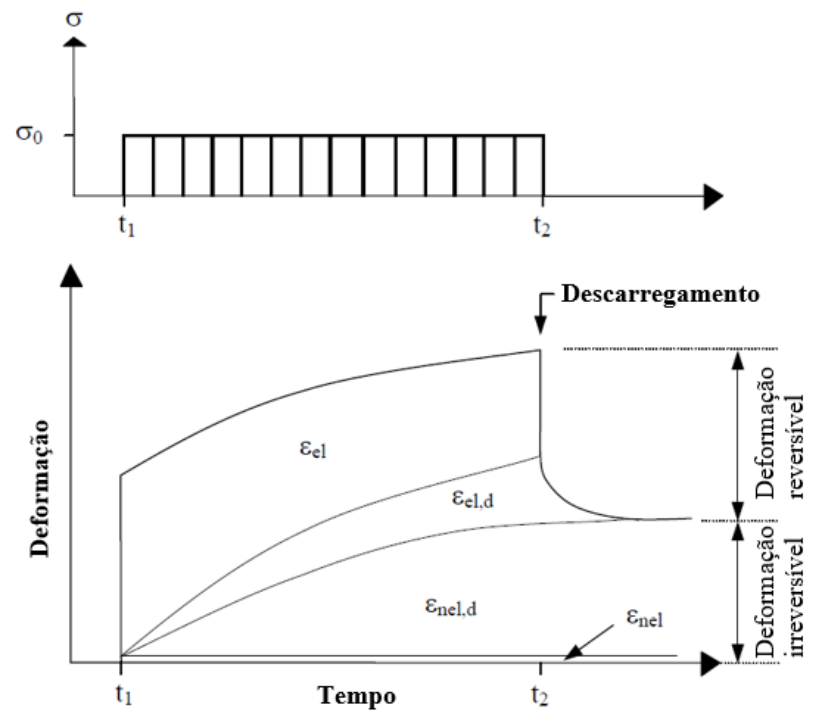

Figura 2.4 - Curva de deformação versus tempo, ilustrando os tipos de deformação, adaptado de Atrushi [9]

Diversos fatores influenciam a deformação por fluência. Esses fatores são definidos por Bazant e Wittmann [8] e divididos entre fatores intrínsecos e fatores extensivos. Os fatores intrínsecos são as características do material, que são fixas uma vez que o concreto é moldado. Os fatores extensivos são aqueles que podem variar depois da moldagem, como a temperatura e umidade da estrutura e do ambiente, idade e duração da aplicação da carga e tipo de carregamento (tensão, compressão ou flexão). A Figura 2.5 ilustra a influência de alguns dos fatores extensivos na fluência. 
a)

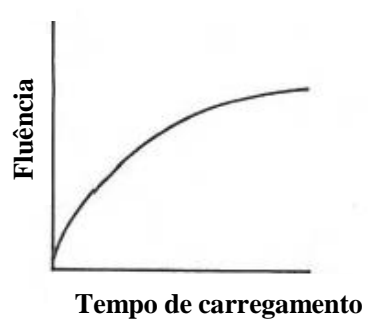

c)

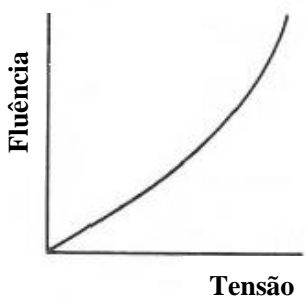

e)

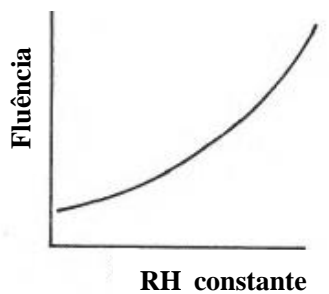

b)

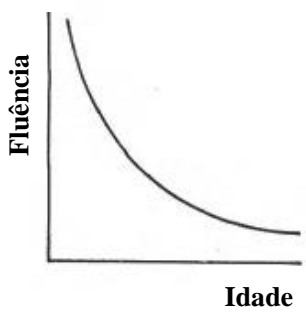

d)

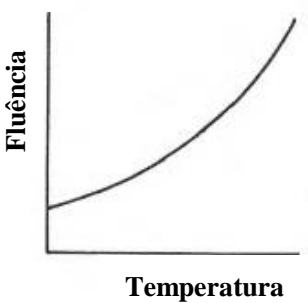

f) Tensão constante

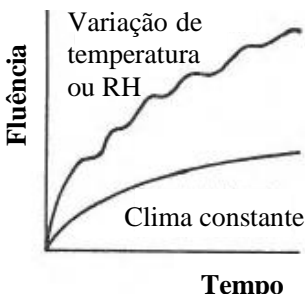

Figura 2.5 - Fatores que influenciam a fluência, adaptado de Byfors [49]

No presente trabalho a fluência foi calculada considerando uma carga constante aplicada durante um período de tempo determinado, sem subtrair a deformação instantânea e deformação devido a retração. No entanto, foi estudada a fluência básica, eliminando os efeitos de retração por secagem durante os ensaios. Além disso, foi estudado o efeito das fibras, considerando a mesma matriz cimentícia.

\subsubsection{Fatores que influenciam a fluência}

Devido a sensibilidade do fenômeno da fluência a compressão a tantos fatores, e a variabilidade dos traços e condições de ensaios encontrados na literatura, a comparação dos resultados sobre o comportamento de materiais cimentícios sob carga constante é normalmente impossível [50].

Fluência a compressão é um efeito de longo prazo e muitos estudos podem ser encontrados na literatura [1, 51-56]. No entanto, existe uma quantidade reduzida de estudos sobre o fenômeno da fluência em idades relativamente jovens 
em concretos [50] e principalmente em pastas de cimento [47], [57-59]. Quando se trata de estudos em materiais cimentícios de idades menores que 7 dias, os resultados apresentados na literatura são ainda mais escassos $[57,58,60]$. O efeito da fluência em concreto de um dia de idade foi estudado por Jiang et al. [58], que observaram grandes variações nos resultados.

\subsubsection{Influência da idade de aplicação da carga}

Ghosh [61] avaliou a deformação por fluência de pastas de cimento seladas e não seladas para diferentes idades de aplicação de carga. O valor da carga foi ajustado continuamente, conforme a pasta ia ganhando resistência, no intuito de manter a razão tensão/resistência constante. $\mathrm{O}$ autor observou que a fluência foi maior quando a aplicação de carga se deu em idades iniciais (18 horas) e menor em idades mais avançadas (28 dias). Para pastas de cimento em fase de endurecimento (idades jovens), a fluência não foi linearmente proporcional à razão tensão/resistência.

Lura et al. [62] estudaram o comportamento de fluência de concreto auto adensável (CAA) para diferentes idades de aplicação de carga (2, 7, 28 dias e ajustes aos 7 e 28 dias). Os autores observaram que para cargas ajustadas aos 7 e 28 dias, a deformação por fluência foi maior. Além disso, observaram que a fluência foi maior para cargas aplicadas em idades mais avançadas. No entanto, o coeficiente de fluência (relação entre deformação por fluência e deformação elástica) apresentou apenas pequenas diferenças na idade de aplicação de carga.

Niyogi [56] observou que a idade de aplicação da carga tem um efeito significativo tanto na fluência básica quanto na fluência por secagem. A fluência básica inicialmente aumentou com a idade no momento de aplicação da carga e depois diminuiu. A fluência por secagem diminuiu uniformemente com a idade.

\subsubsection{Influência do grau de hidratação da pasta de cimento}

Existem muitas teorias para explicar o efeito de fluência em concreto. É conhecido que este fenômeno de fluência tem sua origem na pasta de cimento hidratada [1], mas as razões pela qual a pasta sofre fluência ainda é discutida. Para Schutter e Taerwe [63] a fluência está diretamente relacionada com a evolução do grau de hidratação do cimento. Zhang et al. [1] afirmam que o comportamento de 
fluência em pastas de cimento é determinado principalmente pelas propriedades de fluência do Silicato de Cálcio Hidratado, C-S-H [1]. Sorelli et al. [64] definem que as causas da deformação por fluência são diferentes para idades iniciais e avançadas. A deformação por fluência na pasta de cimento em idades iniciais pode ser associada a difusão do gel de água nos poros e fissuras, e é principalmente uma deformação volumétrica e reversível. A deformação causada em idades avançadas pode ser associada ao deslizamento das camadas de Silicato de Cálcio Hidratado (C-S-H), e é principalmente uma deformação da forma e irreversível [64].

$\mathrm{O}$ estudo do comportamento dessas pastas à fluência em idades iniciais (quando ocorre a hidratação de forma mais intensa) é de grande importância. A carência de dados na literatura sobre este assunto pode ser atribuída à sua complexidade em idades jovens e à dificuldade na realização de ensaios nesta fase [9].

Briffaut et al. [65] observaram que taxa de fluência básica diminuiu com o aumento da idade de aplicação da carga, que corresponde a um aumento do grau de hidratação. Tamtsia et al. [60] observaram que, às 18 horas de idade, o carregamento pode aumentar a hidratação do cimento se comparado às amostras sem carregamento. Porém, depois de 24 horas de idade ou mais, o carregamento tem um efeito negativo no grau de hidratação de pastas com fator agua/cimento de 0,35 e 0,5 .

Němeček [66] avaliou a influência das fases de hidratação das pastas de cimento na fluência. $\mathrm{O}$ autor observou que as fases hidratadas da pasta sofreram significativa deformação por fluência enquanto as partículas de clínquer não hidratados não exibiram deformação por fluência nas cargas aplicadas.

Parrott [67] investigou o efeito da fluência em amostras secas e úmidas com diferentes fatores água/cimento $(\mathrm{a} / \mathrm{c})$. A fluência diminuiu para ambas as amostras e todos os fatores a/c com o aumento da idade de aplicação da carga de até $60 \%$ da resistência máxima. Segundo o autor, um rearranjo da estrutura da pasta envolvendo uma pequena parte do volume total poderia ser responsável por esta redução da fluência. Além disso, foi visto que o grau de hidratação das amostras secas não se alterou depois de seladas, enquanto as amostras úmidas continuaram hidratando. Tendo em vista esse comportamento, o autor sugeriu que o efeito da idade de aplicação da carga na fluência do concreto é resultado do comportamento de envelhecimento da pasta endurecida e não apenas devido à hidratação contínua. $\mathrm{Ou}$ 
seja, os efeitos da hidratação não são suficientes para explicar a redução da fluência com a idade de aplicação da carga.

\subsubsection{Influência da umidade relativa (UR)}

Wyrzykowski e Lura [68] estudaram o efeito da umidade relativa (UR) de argamassas sob fluência. Os resultados mostraram um aumento significativo da UR no momento de aplicação da carga (26 MPa), sendo este aumento visível até para cargas mais baixas $(2,5 \mathrm{MPa})$. A umidade relativa reduziu gradualmente (depois desse aumento inicial da UR) durante o avanço na idade da amostra com carga constante. Segundo os autores, a redistribuição de água na aplicação da carga e a correspondente variação da UR poderiam explicar apenas a deformação de idades iniciais (segundos a minutos) do concreto. Para a redução gradual da UR durante a fluência, os autores propuseram dois possíveis mecanismos. O primeiro seria que a água adicional fornecida durante a redistribuição seria consumida na hidratação, sendo, portanto, a auto dessecação resultante responsável pela redução gradual da UR. O segundo mecanismo seria uma redistribuição adicional da água em escala macroscópica. Dessa maneira, a água que migrou inicialmente de áreas adsorvidas para maiores espaços de poros capilares ou gel migraria para vazios capilares ainda maiores, para fissuras ou para os limites da amostra (em casos onde a vedação não fosse perfeita).

Sorelli et al. [64, 69] estudaram o efeito da umidade relativa (UR) no comportamento de fluência de pastas de cimento. Os autores observaram que a fluência tanto em idades jovens quanto em idades avançadas aumentou com o aumento da umidade relativa. Este comportamento pode ser explicado, segundo os autores, por efeitos de secagem através de microfissuras ou por forças locais que estariam agindo nas camadas de Silicato de Cálcio Hidratado.

Bazant et al. [70] avaliaram a influência da variação da umidade na taxa da fluência e concluíram que essa variação, positiva ou negativa, acelerou significantemente a fluência. Os autores também observaram que a variação da temperatura numa umidade constante de $75 \%$ durante o ensaio acelerou muito mais a fluência do que em umidade de $99 \%$.

Bennett e Loat [30] avaliaram o efeito do fator água/cimento (a/c) variando entre 0,3 e 0,525 na fluência para ambientes com umidades de 55 e $100 \%$. Foi 
observado que a fluência aumentou com o aumento do fator a/c, e que para umidade de $100 \%$, o impacto do fator a/c se tornou menor.

\subsubsection{Influência da temperatura}

Vidal et al. [59] estudaram o comportamento de fluência básica de concretos de alta performance sujeitos a temperaturas de 20,50 e $80^{\circ} \mathrm{C}$ com carga aplicada aos 320 dias para assegurar que a hidratação estivesse estabilizada. Os autores observaram que aos 300 dias as amostras submetidas a temperatura de $50^{\circ} \mathrm{C}$ apresentaram deformações aproximadamente 2 a 3,7 vezes maiores do que as amostras submetidas a $20^{\circ} \mathrm{C}$. Os autores afirmam que a viscosidade da água pode ser alterada para temperaturas entre 20 e $50^{\circ} \mathrm{C}$, aumentando o deslizamento das camadas de C-S-H. Já para o caso de amostras a $80^{\circ} \mathrm{C}$, a deformação por fluência foi afetada de forma significativa. Aos 20 dias de ensaio a deformação foi entre 5,7 e 9,2 vezes maior. Segundo os autores, este aumento pode ter sido induzido por algum dano causado pela alta temperatura, observado pela redução do módulo de elasticidade.

Briffaut et al. [65] estudaram a influência da temperatura na deformação por fluência básica de concretos em idades jovens. Os autores observaram o comportamento da fluência em temperaturas de 20 e $60^{\circ} \mathrm{C}$. Foi constatado que a deformação do concreto a $60^{\circ} \mathrm{C}$ foi quase 2 vezes maior que a medida a $20^{\circ} \mathrm{C}$. Também foi avaliado pelos autores o impacto da variação da temperatura (de 60 para $20^{\circ} \mathrm{C}$ ) no comportamento de fluência do concreto. Concluiu-se que a variação de temperatura teve um maior impacto na fluência se comparado a temperatura constante de 20 ou $60^{\circ} \mathrm{C}$. Isso poderia ser explicado devido a uma possível alteração na mobilidade da água do concreto. Essa alteração seria causada pelo aumento na taxa de deformação por fluência devido a mudança de temperatura ("thermal transiente creep").

Arthanari e Yu [71] também chegaram a resultados similares de deformações quando compararam concretos ensaiados a 20 e $80^{\circ} \mathrm{C}$. Além disso, os autores observaram que o incremento de temperatura ao longo do ensaio influenciou mais a deformação por fluência do que manter a temperatura máxima constante desde o início. 


\subsubsection{Influência da finura e do tipo de cimento na fluência}

Lura et al. [62] estudaram o comportamento de fluência de concreto auto adensável (CAA) e concreto vibrado de forma convencional (CVC) com mesmo fator água/cimento $(0,40)$. Foram testados 3 tipos de cimento: CEM I $42.5 \mathrm{~N}$ (apenas clínquer [72]), CEM II/ B-M (V-LL) 32.5 R (adição de cinza volante e calcário [72]) e CEM III/B 42.5 L-LH HS (adição de escória de alto forno [72]) para cada tipo de concreto, CAA e CVC. Segundo os autores, o volume da pasta e o tipo de cimento desempenham um papel fundamental na fluência. Os concretos CAA tinham maior volume de pasta e apresentaram maiores valores de fluência quando comparados com concretos CVC com o mesmo tipo de cimento, sendo a maior diferença observada para o cimento tipo CEM I. Quando comparados os tipos de cimento, a amostra contendo CEM I apresentou maior deformação para ambos os concretos, e as amostras com CEM III apresentaram a menor deformação.

Vidal et al. [59] investigaram o efeito da fluência em dois tipos de cimento, o CEM I (clínquer [72]) e o CEM V (adição de escória de alto forno e cinza volante [72]) e observaram que a deformação por fluência no primeiro foi maior que no segundo tipo de cimento.

Bennett e Loat [30] investigaram a influência da finura do cimento na fluência. Os corpos de prova com cimento mais fino apresentaram maiores valores de fluência em idades iniciais, e, segundo os autores, isso ocorreu por causa da hidratação mais rápida. Em idades avançadas (1000 dias), a deformação por fluência foi menor para amostras com cimento mais fino. Isso poderia ser justificado por um ganho de resistência inicial maior em amostras com cimento mais fino.

\subsubsection{Influência das fibras na fluência}

Muito se tem estudado sobre o efeito das fibras na fluência a compressão de concretos, e poucos estudos em pastas vêm sendo desenvolvidos. A maioria desses trabalhos analisaram o efeito de fibras de aço. Existem muito poucos estudos sobre fluência a compressão em concreto e pasta de cimento reforçados com fibras de polipropileno (PP) ou fibra natural $[52,73]$, e nenhum estudo da influência da fibra de curauá. Aslani e Nejadi [52] observaram que a adição de $5 \mathrm{~kg} / \mathrm{m}^{3}$ de fibra de 
polipropileno de $65 \mathrm{~mm}$ de comprimento reduziu cerca de $19 \%$ a fluência aos 7 dias, mas aumentou cerca de $11 \%$ no $364^{\circ}$ dia, quando comparado ao concreto de referência.

$\mathrm{O}$ efeito combinado de fibras de polipropileno (PP) e aço em concreto foi estudado por Błyszko [50] com o objetivo de que as fibras de PP trabalhassem principalmente no concreto em idades jovens e as fibras de aço em idades mais avançadas. Eles observaram que a deformação por fluência a compressão em idades jovens aumentou com o uso combinado dessas fibras, mas que depois das primeiras horas, a fluência do concreto com e sem fibras se desenvolveu de forma semelhante.

Ramaswamy et al. [73] concluíram que a adição de $1 \%$ fibras de $15 \mathrm{~mm}$ de juta, de coco e de bambu no concreto aumentou a deformação por fluência em 25\%, $25 \%$ e $12 \%$, respectivamente. No entanto, os próprios autores concordam que são necessários mais estudos para entender o efeito das fibras naturais na fluência. Sales [44] estudou a influência de poupa de bambu na fluência de pastas de cimento em idades avançadas (120 dias) e concluiu que tanto a fluência básica quanto a total aumentaram com a adição dessa fibra. No entanto, o aumento foi mais significativo na fluência básica, que também foi influenciada pelo teor de fibras na mistura.

Toledo Filho [74] observou uma redução de $8 \%$ e $23 \%$ na fluência básica em idades avançadas (350 dias) de argamassas reforçadas com $2 \%$ fibras de $25 \mathrm{~mm}$ de comprimento de sisal e coco, respectivamente. Essa redução foi proporcional ao aumento do teor de fibras na mistura. $\mathrm{O}$ autor também avaliou a influência do comprimento de fibras de sisal na fluência, e observou que o comportamento à fluência de argamassas com fibras de 15 ou $25 \mathrm{~mm}$ apresentaram aproximadamente os mesmos valores. O comportamento desses compósitos quando submetidos à fluência total foi diferente. Para argamassas com fibra de coco, a fluência total teve uma redução de até $8 \%$ aos 210 dias de idade. Já para argamassas com fibra de sisal, o comportamento do compósito gerou um aumento de até $16 \%$ na fluência total aos 210 dias. Segundo o autor, o melhor desempenho da fibra de coco em ambas as fluências poderia estar relacionado com a sua menor porosidade e menor absorção de água, se comparada a fibra de sisal.

Mangat e Azari $[75,76]$ analisaram o efeito de fluência em pastas de cimento reforçados com fibras de aço. Foi observado uma redução substancial da deformação por fluência dessas pastas em comparação as pastas sem reforço fibroso. Os autores observaram também que essa redução devido ao reforço fibroso 
foi muito maior para pastas de cimento do que em matrizes de concreto e argamassa, que apresentaram reduções similares.

O estudo do comportamento do concreto reforçado com fibras de aço sob fluência a compressão já é bem estabelecido na literatura e foi estudado por diversos autores [54, 55, 75, 77-80]. Entretanto, não existe consenso sobre o papel das fibras de aço na deformação por fluência. Muitos autores demonstraram que o uso de fibras de aço contribui significativamente na redução da fluência a compressão do concreto em idades avançadas e que isso ocorre tanto para fluência básica [55, 81] quanto por secagem $[54,55,75,76]$. Também foi observado que essa redução se intensifica com o aumento do teor de fibras de aço [54, 55, 75, 76, 82]. No entanto, alguns autores sugerem que as fibras de aço influenciam pouco a fluência a compressão $[79,80]$. 


\section{Procedimento Experimental}

Este capítulo descreve o programa experimental desenvolvido com o objetivo de atender as premissas desta pesquisa. São elas: a avaliação do comportamento de pastas de cimento com reforço fibroso na retração e na fluência. Todas as misturas foram fabricadas com o mesmo fator água/cimento e mesmo tipo de cimento classe G. As variáveis desta pesquisa foram o teor de fibras - $0,3 \mathrm{~kg} / \mathrm{m}^{3}, 1,2 \mathrm{~kg} / \mathrm{m}^{3}$ e $2,7 \mathrm{~kg} / \mathrm{m}^{3}$, e o tipo de reforço fibroso - polipropileno ou curauá. A Figura 3.1 resume os ensaios realizados neste trabalho.

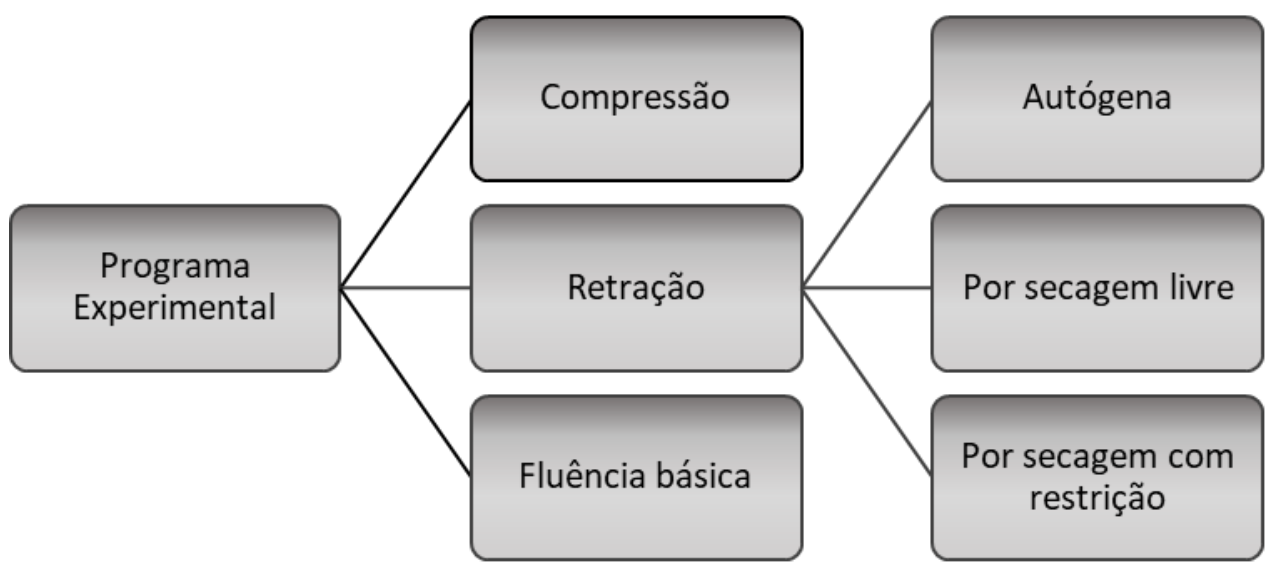

Figura 3.1 - Organização do programa experimental

\subsection{Materiais Utilizados}

\subsubsection{Material Cimentício}

A mistura da pasta de cimento de referência foi feita com água encanada e cimento Classe G HSR, disponibilizado pela Lafarge Holcim. O cimento foi fornecido em dois lotes diferentes, sendo o primeiro utilizado para os ensaios de retração por secagem livre, pelo método de variação de comprimento (primas), e de fluência a compressão, e o segundo lote para os ensaios de retração autógena, pelo método do tubo corrugado, e de retração por secagem com restrição, pelo método do anel. A caracterização, segundo o fabricante, dos dois lotes de cimento se encontra na Tabela 3.1. O fator água/cimento para todas as misturas foi de 0,44 . 
Tabela 3.1 - Propriedades dos cimentos classe G

\begin{tabular}{|c|c|c|c|c|c|}
\hline \multicolumn{3}{|c|}{ Composição Química (\%) } & \multicolumn{3}{|c|}{ Composição Mineral (\%) } \\
\hline & Lote I & Lote II & & Lote I & Lote II \\
\hline $\mathrm{SiO}_{2}$ & 22,5 & 21,5 & $C_{3} S(A P I$ 10A) & 53 & 65 \\
\hline $\mathrm{Al}_{2} \mathrm{O}_{3}$ & 3,8 & 3,79 & $C_{3} S$ (NBR 9831) & 51 & 61 \\
\hline $\mathrm{Fe}_{2} \mathrm{O}_{3}$ & 4,52 & 4,59 & $C_{3} A$ & 2,4 & 2,3 \\
\hline $\mathrm{CaO}$ & 64,87 & 65,38 & $C_{4} A F$ & 14 & 14 \\
\hline MgO & 1,2 & 1,3 & $C_{4} A F+2 C_{3} A$ & 19 & 19 \\
\hline $\mathrm{SO}_{3}$ (total) & 2,62 & 2,56 & \multicolumn{3}{|c|}{ Características Físicas } \\
\hline CaO livre & 0,61 & 0,98 & Densidade $\left(\mathrm{g} / \mathrm{cm}^{3}\right)$ & 3,17 & 3,17 \\
\hline $\mathrm{Na}_{2} \mathrm{O}$ & 0,15 & 0,28 & Blaine - finura $\left(\mathrm{cm}^{2} / \mathrm{g}\right)$ & 2976 & 2900 \\
\hline $\mathrm{K}_{2} \mathrm{O}$ & 0,32 & 0,42 & & & \\
\hline $\mathrm{Na}_{2} \mathrm{O}_{e q}$ & 0,36 & 0,56 & & & \\
\hline Resíduo Insolúvel & 0,32 & 0,47 & & & \\
\hline Perda ao Fogo & 0,88 & 1,12 & & & \\
\hline
\end{tabular}

\subsubsection{Fibras}

Foram utilizadas fibras de curauá e polipropileno no tamanho de $12 \mathrm{~mm}$, como ilustra a Figura 3.2. As dosagens utilizadas foram de $0,3,1,2$ e $2,7 \mathrm{~kg} / \mathrm{m}^{3}$ para ambas as fibras. A Tabela 3.2 apresenta algumas características das fibras utilizadas neste trabalho. As fibras de polipropileno foram produzidas e fornecidas pelo fabricante Viapol, da Euclid Group, prontas para uso.

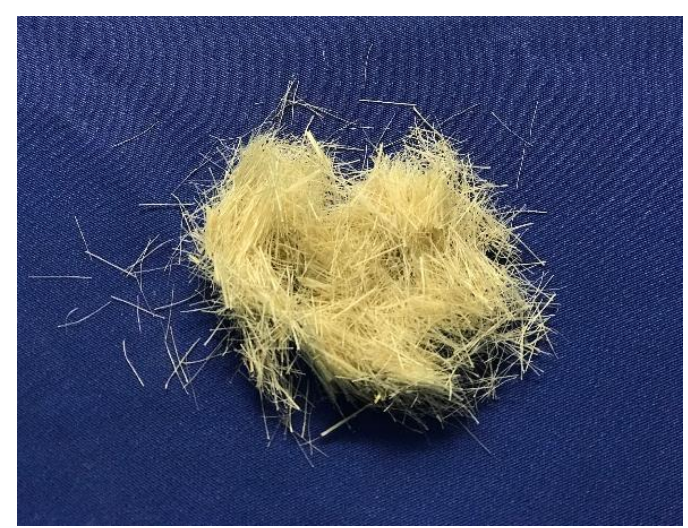

(a)

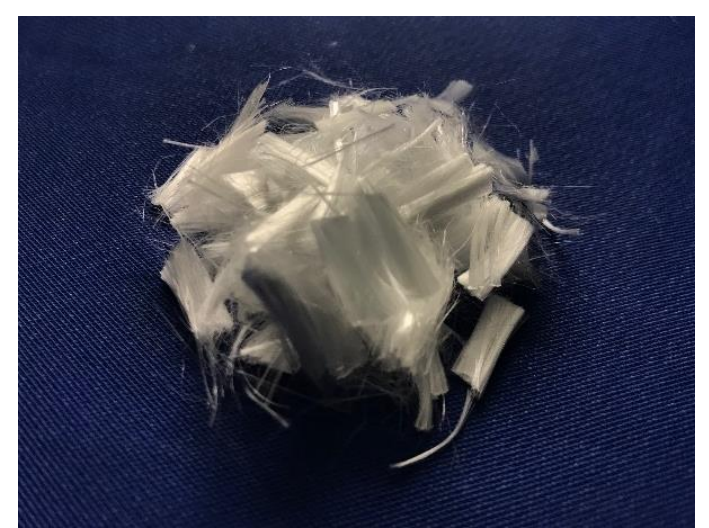

(b)

Figura 3.2 - Fibras utilizadas: (a) fibra de curauá $12 \mathrm{~mm}$; (b) fibra de polipropileno $12 \mathrm{~mm}$ 
Tabela 3.2 - Características das fibras de curauá e polipropileno

\begin{tabular}{lcc}
\hline \multicolumn{1}{c}{ Tipo de fibra } & Curauá & Polipropileno \\
\hline Densidade, $\mathbf{k g} / \mathbf{m}^{\mathbf{3}}$ & $0,9^{a}$ & 0,91 \\
Comprimento, $\mathbf{m m}$ & 12 & 12 \\
Absorção de água & $3,5^{a, b}$ & Desprezível \\
Módulo de Elasticidade, $\mathbf{~ G P a}$ & $27,6 \pm 6,7^{a}$ & $3,5-4,8^{c}$ \\
Resistência a tração, $\mathbf{M P a}$ & $543,1 \pm 147,6^{a}$ & $300-400^{c}$ \\
Dosagem, $\mathbf{k g} / \mathbf{m}^{\mathbf{3}}$ (\%) & $0,3(0,03) ; 1,2(0,13) ; 2,7(0,3)$ \\
\hline
\end{tabular}

${ }^{a}$ valores obtidos por Souza [83]

${ }^{b}$ valor se refere ao peso final da fibra em relação ao seu peso inicial

${ }^{c}$ valores obtidos por Yousefieh et al. [36]

As fibras de curauá lavadas em água com temperatura entre 70 e $80{ }^{\circ} \mathrm{C}$ durante 1 hora. Em seguida, as fibras foram colocadas ao ar livre para secagem por cerca de 24 horas. Este tratamento foi aplicado a fim de que fossem removidas as impurezas retidas em sua superfície. Depois de secas, as fibras de curauá foram penteadas em um aparato e depois cortada no tamanho desejado. $\mathrm{O}$ aparato para pentear as fibras consistia em uma peça de madeira com pregos fixada em uma bancada com auxílio de dois grampos C. Após isto, antes de serem acrescentadas a mistura, as fibras foram saturadas com água durante três horas para que não absorvessem a água da pasta. A Figura 3.3 apresenta as etapas do tratamento, bem como o antes e depois da fibra de curauá. 


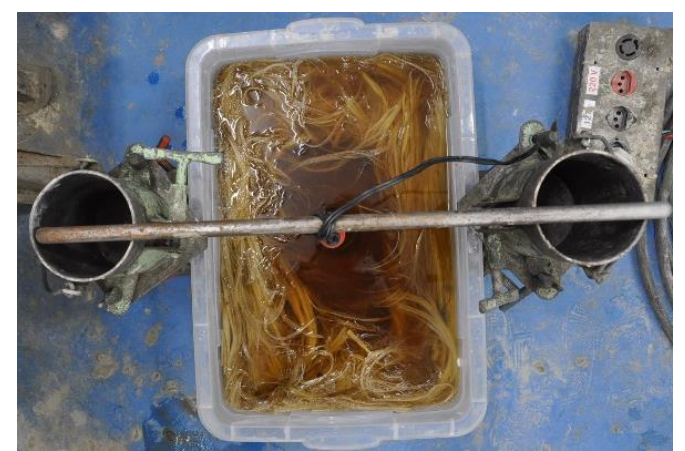

(a) Fibras imersas em água com temperatura entre 70 e $80^{\circ} \mathrm{C}$

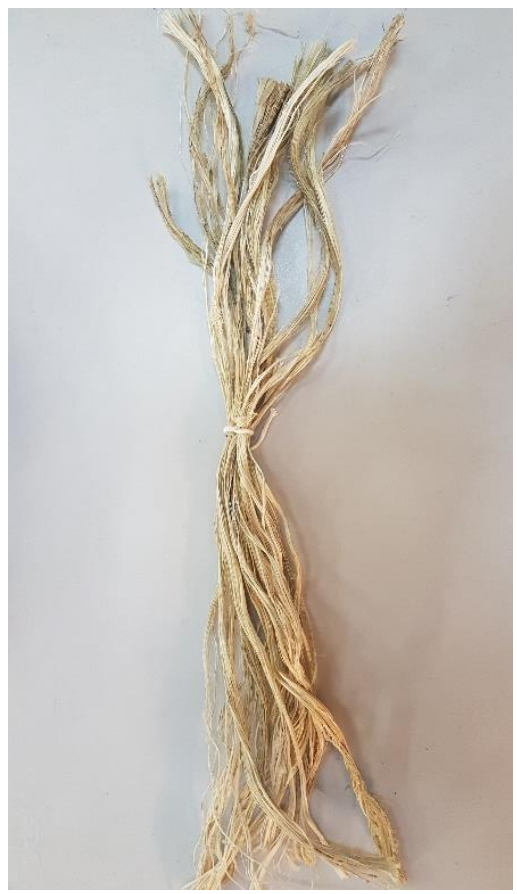

(c) Fibras antes de receber o tratamento

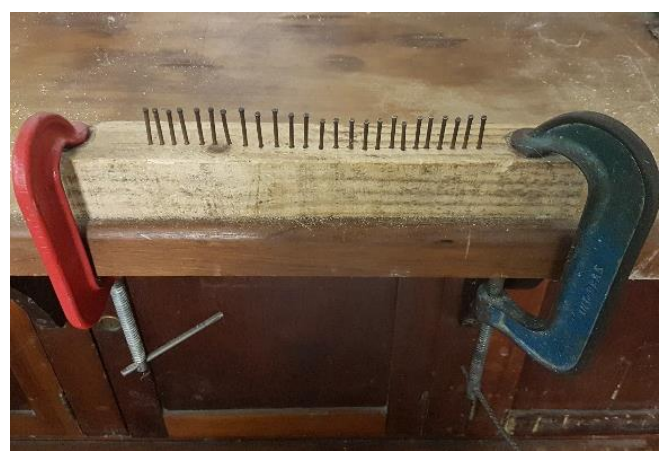

(b) Aparato utilizado para pentear as fibras de curauá

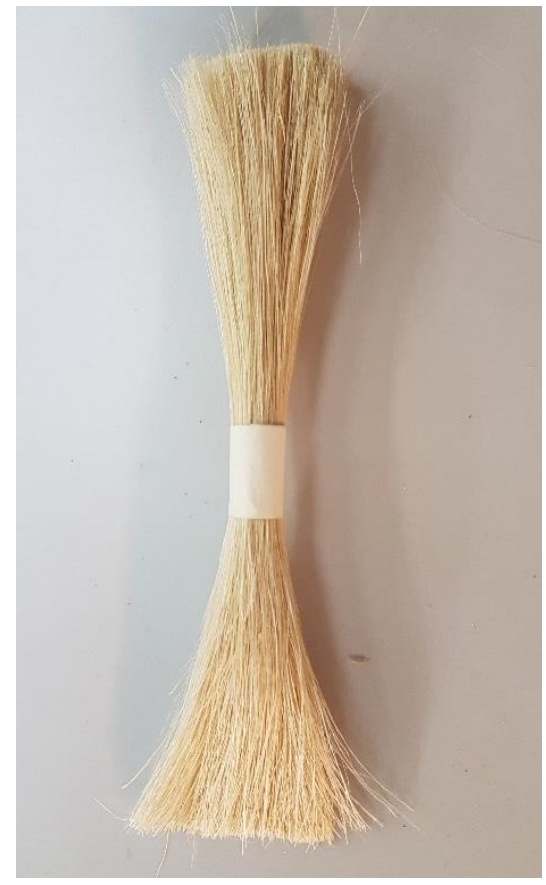

(d) Fibras depois de tratadas

Figura 3.3 - Etapas do tratamento das fibras de curauá

\subsubsection{Superplastificante}

A quantidade de aditivo superplastificante usado na dosagem das misturas foi ajustada no intuito se obter a trabalhabilidade desejada. $\mathrm{O}$ aditivo utilizado foi o MasterGlenium ${ }^{\circledR}$ 51, com o teor de sólidos de 32\% e $68 \%$ de água. Este superplastificante é a base de éter policarboxílico e foi produzido pelo fabricante BASF. 


\subsection{Método de Mistura}

As misturas foram feitas em três misturadores diferentes, de acordo com a quantidade de material utilizado. Para a moldagem dos prismas e dos tubos corrugados foi utilizado o misturador menor, com capacidade para 1,5 litros. Para a moldagem dos cilindros para os ensaios de fluência e de compressão, o misturador médio foi utilizado e tinha capacidade máxima de 5 litros. O misturador grande, com capacidade para 20 litros foi utilizado para a moldagem dos ensaios de retração com restrição. A Figura 3.4 apresenta os 3 misturadores utilizados na pesquisa. A pesagem da água e do cimento foram feitas em balanças com precisão de $0,001 \mathrm{~kg}$ e a pesagem das fibras e superplastificante foi feita em balança com precisão de $0,001 \mathrm{~g}$.

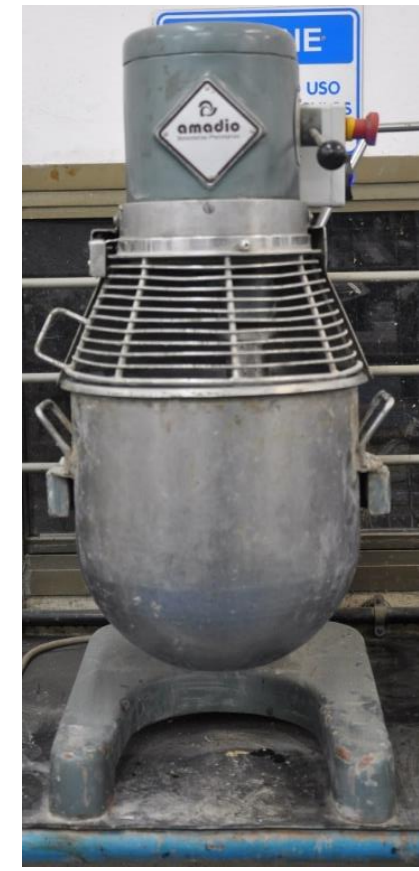

(a)

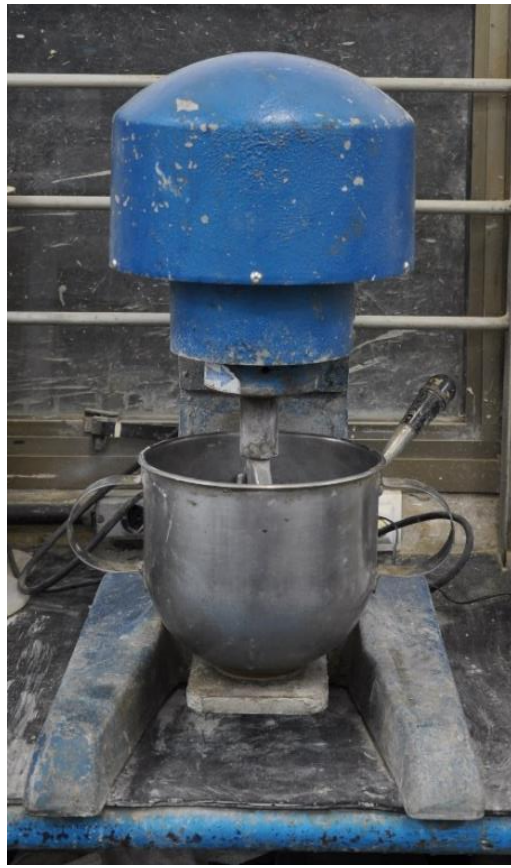

(b)

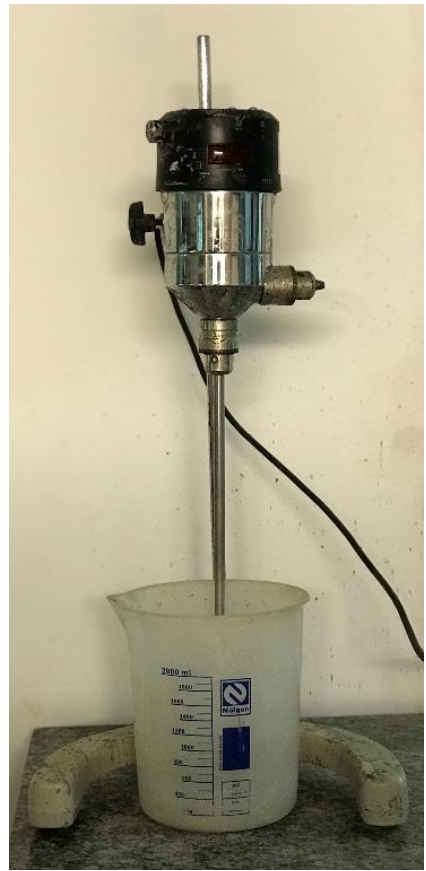

(c)

Figura 3.4 - Misturadores utilizados no preparo das amostras: (a) Misturador 201, (b) Misturador 51 e (c) Misturador 1,51

\subsubsection{Moldagem}

A moldagem dos corpos de prova foi realizada de forma semelhante para todos os ensaios desta pesquisa. Foi necessária uma variação no tempo de mistura de algumas etapas devido ao tamanho do misturador utilizado e, consequentemente, volume de pasta misturada. A mistura se deu da seguinte forma: primeiro foi 
adicionado superplastificante na água e deixado misturar por 30 segundos para o misturador pequeno e 1 minuto para os demais misturadores. Depois, foi adicionado o cimento e deixado misturando por mais 30 segundos para o caso do misturador pequeno e médio, e 1 minuto para o misturador grande. Em seguida, esse mesmo intervalo de tempo foi utilizado para retirar as misturas nas paredes do recipiente, enquanto os misturadores se apresentavam desligados. Por fim, as fibras foram adicionadas e os misturadores foram novamente ligados por 30 segundos para os misturadores pequenos e 1 minuto para os demais misturadores. A tabela 3.3 resume os tempos de cada uma das etapas de mistura das pastas, por tipo de misturador utilizado na presente pesquisa.

Tabela 3.3 - Tempo das etapas de mistura das pastas por tipo de misturador utilizado

\begin{tabular}{lccc}
\hline \multicolumn{1}{c}{$\begin{array}{c}\text { Etapas } / \\
\text { Misturadores }\end{array}$} & $\begin{array}{c}\text { Pequeno } \\
(\mathbf{1 , 5} \text { litros) }\end{array}$ & $\begin{array}{c}\text { Médio } \\
\text { (5 litros) }\end{array}$ & $\begin{array}{c}\text { Grande } \\
\text { (20 litros) }\end{array}$ \\
\hline $\begin{array}{l}\text { Água + } \\
\text { superplastificante }\end{array}$ & 30 segundos & 1 minuto & 1 minuto \\
$\begin{array}{l}\text { Adição de cimento } \\
\begin{array}{l}\text { Raspagem das } \\
\text { laterais }\end{array}\end{array}$ & 30 segundos & 30 segundos & 1 minuto \\
\begin{tabular}{l} 
Adição de fibras \\
\hline
\end{tabular} & 30 segundos & 30 segundos & 1 minuto \\
\hline
\end{tabular}

Para o ensaio de retração autógena, foram utilizados moldes de tubos corrugados. Esses tubos foram moldados em quatro camadas, em uma mesa vibratória, com o objetivo de reduzir os vazios da amostra. O início do ensaio de retração autógena pelo método do tubo corrugado se deu 30 minutos após a mistura da água com o cimento.

Os moldes prismáticos foram usados nos ensaios de retração livre. Os prismas foram moldados em duas camadas, e a cada camada foram dados golpes nas laterais para auxiliar o preenchimento da forma e retirar o ar. Após a moldagem, foram selados com plástico filme na parte superior. Os prismas foram desmoldados com $15 \pm 1$ h e ensaiados em seguida.

Os ensaios de retração por secagem com restrição foram realizados em moldes em formato de anel. Esses anéis foram moldados em 3 camadas. A cada camada foi utilizado uma espátula para auxílio do preenchimento da forma. A parte superior do molde foi selada com plástico filme. $\mathrm{O}$ anel de aço externo do teste do 
anel foi retirado $15 \pm 1$ h após a moldagem, mas a leitura dos dados de deformação do anel de aço interno ocorreu desde o instante inicial do preenchimento da forma.

Foram utilizados moldes cilíndricos para os ensaios de compressão e fluência. A pasta foi colocada no molde em duas camadas. A cada camada os moldes eram colocados em mesa vibratória a fim de assentar a pasta e retirar o ar, reduzindo os vazios do corpo de prova. Após a moldagem, a parte superior dos cilindros foi selada com plástico filme, para evitar perda de água durante a cura. Os cilindros foram tirados da forma 24 horas após a moldagem, Em seguida, foram colocados em recipiente com água e cal para a cura até a idade desejada para realização dos ensaios. Antes dos ensaios, os corpos de prova cilíndricos foram faceados no equipamento retifica planificadora da Setor Indústria para nivelamento da superfície.

\subsubsection{Identificação dos corpos de prova}

Os corpos de prova de pasta de cimento foram identificados pelo tipo de fibras (C ou PP) e seus teores $(0,3,1,2$ ou 2,7), pelo lote do cimento utilizado (para o caso da pasta de referência) e pelo teor de $\mathrm{C}_{3} \mathrm{~S}$ contido no respectivo lote. A tabela 3.4 apresenta a abreviação e a respectiva descrição das misturas.

Tabela 3.4 - Descrição das legendas utilizadas na pesquisa

\begin{tabular}{|c|c|}
\hline Abreviação & Descrição \\
\hline Ref_LI53 & Cimento Lote I com teor de $53 \%$ de C3S \\
\hline Ref_LII65 & Cimento Lote II com teor de $65 \%$ de C3S \\
\hline$P P O, 3 \mathrm{~kg} / \mathrm{m}^{3}$ & Pastas com $0,3 \mathrm{~kg} / \mathrm{m}^{3}$ de polipropileno \\
\hline$P P 1,2 \mathrm{~kg} / \mathrm{m}^{3}$ & Pastas com $1,2 \mathrm{~kg} / \mathrm{m}^{3}$ de polipropileno \\
\hline$P P 2,7 \mathrm{~kg} / \mathrm{m}^{3}$ & Pastas com $2,7 \mathrm{~kg} / \mathrm{m}^{3}$ de polipropileno \\
\hline 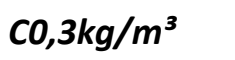 & Pastas com 0,3 kg/m de curauá \\
\hline$C 1,2 \mathrm{~kg} / \mathrm{m}^{3}$ & Pastas com $1,2 \mathrm{~kg} / \mathrm{m}^{3}$ de curauá \\
\hline$C 2,7 \mathrm{~kg} / \mathrm{m}^{3}$ & Pastas com 2,7 kg/m $/ \mathrm{m}^{3}$ de curauá \\
\hline
\end{tabular}

A quantidade de corpos de prova variou de acordo com o ensaio realizado, sendo, no total, 5 corpos de prova no tubo corrugado, 7 anéis, 45 primas, 24 cilindros para fluência e 48 para compressão. 


\subsection{Métodos de ensaios}

Os ensaios que se fizeram necessários para o desenvolvimento desta pesquisa foram os seguintes: o de trabalhabilidade, tempo de pega, retração autógena, retração por secagem livre e com restrição e o de fluência a compressão. Com exceção dos ensaios de retração autógena e fluência, os demais ensaios já são executados de forma habitual no laboratório. Assim, para os ensaios de retração autógena e fluência foram dedicados um item para cada a fim de apresentar a evolução do desenvolvimento da metodologia para execução dos mesmos.

\subsubsection{Espalhamento}

O teste de espalhamento das pastas de cimento com e sem fibras foi realizado de forma similar ao ensaio de mini abatimento desenvolvido por Kantro [84], a fim de garantir uma trabalhabilidade aproximada entre as misturas. Um molde cônico de dimensões 4 × $8 \times 7 \mathrm{~cm}$ (altura, diâmetro da base e do topo, respectivamente) foi apoiado em uma placa lisa de vidro e enchido com pasta de cimento (Figura 3.5(a)). O preenchimento do cone foi feito em 3 camadas, sendo aplicados 10 golpes com uma barra fina a cada camada. Depois, com as duas mãos e de forma sutil, o cone foi levantado numa velocidade aproximadamente constante. Foram feitas duas medidas perpendiculares do diâmetro, $\mathrm{H} \mathrm{e} \mathrm{V}$, como ilustrado na Figura 3.5(b). O resultado do teste e a média deles para cada mistura está apresentado na Tabela 3.5.

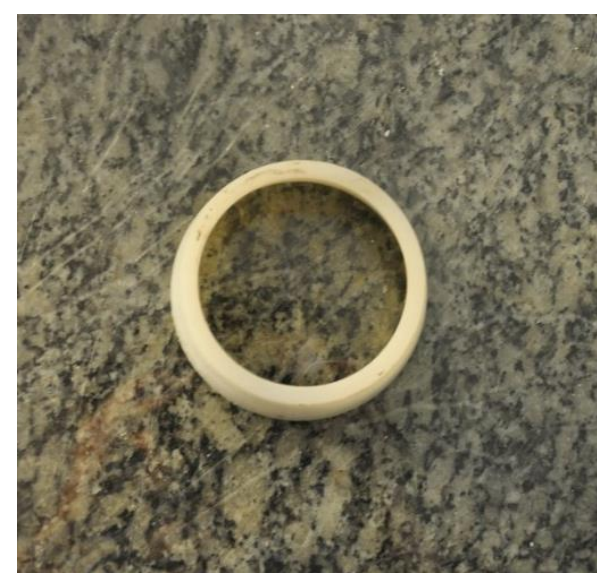

(a)

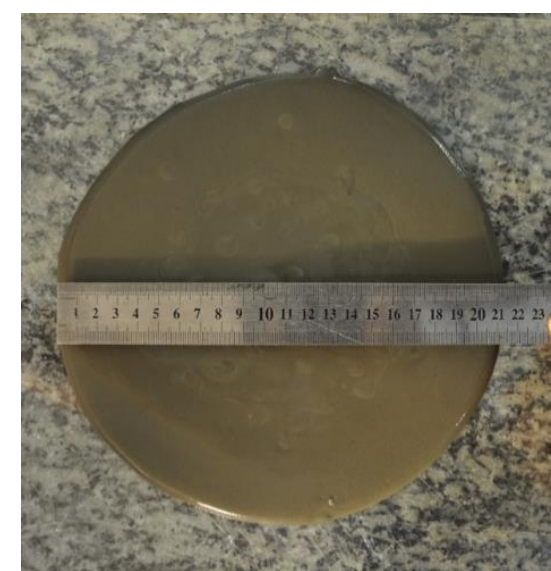

(b)

Figura 3.5 - Ensaio de espalhamento: (a) molde cônico para o teste de espalhamento e (b) medição do espalhamento da pasta de cimento 
Tabela 3.5 - Resultados dos testes de espalhamento das pastas de cimento com e sem fibras

\begin{tabular}{lccc}
\hline & $\boldsymbol{H}(\mathbf{m m})$ & $\boldsymbol{V}(\mathbf{m m})$ & Média $(\mathbf{m m})$ \\
\hline Ref_L153 & 165 & 170 & 167,5 \\
C0,3 & 200 & 205 & 202,5 \\
C1,2 & 160 & 160 & 160 \\
C2,7 & 185 & 185 & 185 \\
PP0,3 & 175 & 175 & 175 \\
PP1,2 & 190 & 190 & 190 \\
PP2,7 & 165 & 170 & 167,5 \\
\hline
\end{tabular}

\subsubsection{Tempo de pega}

O ensaio para obtenção do tempo de fim de pega foi realizado de acordo com a NBR 16607 [85] “Cimento Portland - Determinação dos tempos de pega”. A pasta de referência contendo cimento do lote I foi colocada num molde cônico (Figura 3.6(a)), de dimensões $4 \times 8 \times 7 \mathrm{~cm}$ (altura, diâmetro da base e do topo, respectivamente) e posicionada no aparelho de Vicat.

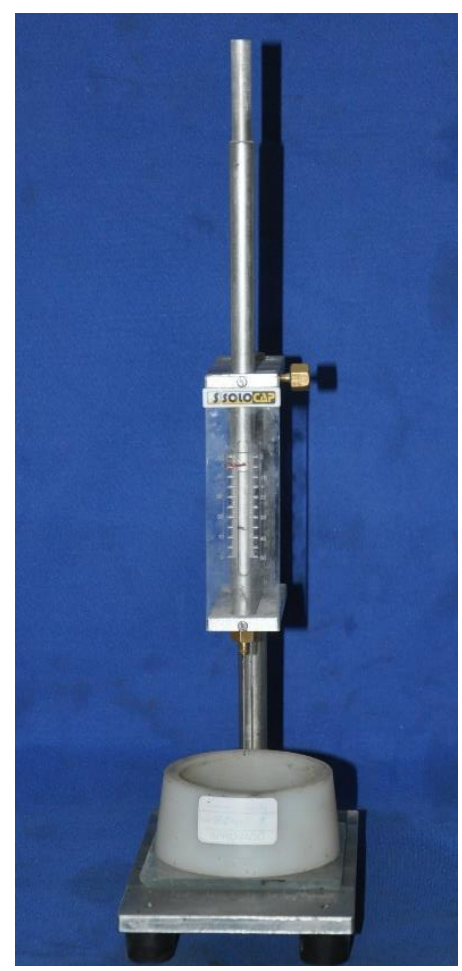

Figura 3.6 - Aparelho de Vicat utilizado para determinação do tempo de pega 


\subsubsection{Retração autógena}

Este item foi dividido em duas partes. A primeira parte apresenta a descrição do ensaio de retração autógena pelo método do tubo corrugado realizado nesta pesquisa. A segunda parte apresenta as tentativas de se implementar este método seguindo as orientações da ASTM 1698 [86].

\subsubsection{Descrição do ensaio executado}

Os ensaios para avaliação da deformação devido à retração autógena foram realizados pelo método do tubo corrugado conforme a ASTM C1698 [86]. Este método une as vantagens dos métodos linear e volumétrico, e ao mesmo tempo minimiza as desvantagens. O tubo corrugado é flexível na direção longitudinal e relativamente rígido na direção radial, permitindo assim a leitura da variação do volume da pasta como variação de comprimento [87] e é selado nas extremidades para evitar perda de umidade. Além disso, permite que o ensaio comece logo após a moldagem dos tubos corrugados [86].

O tubo corrugado de plástico da Germann Instruments (AS-1150100) com tampões apertados nas duas extremidades foi utilizado nesta pesquisa. $\mathrm{O}$ suporte para o corpo de prova foi usinado de acordo com as recomendações da ASTM 1698 [86]. Foi moldado um tubo corrugado com $420 \pm 5 \mathrm{~mm}$ de comprimento quando relaxado e diâmetro externo de $29 \pm 0,5 \mathrm{~mm}$ para cada mistura (Figura 3.7).

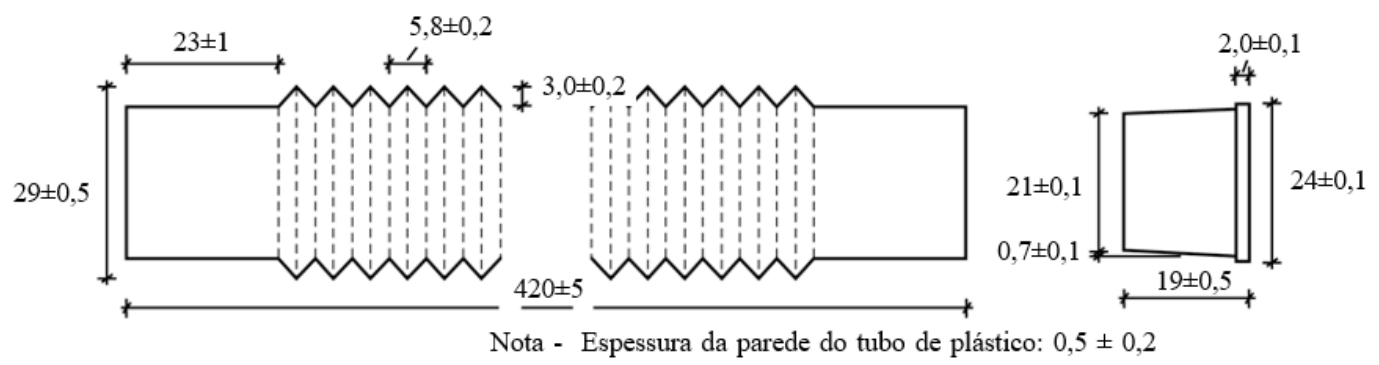

Figura 3.7 - Dimensões (em mm) do tubo corrugado de polietileno, adaptado de ASTM 1698 [86]

A variação do comprimento do tubo foi medida automaticamente a cada 1 minuto ou variação de $0,005 \mathrm{~mm}$ de comprimento. A moldagem dos corpos de prova consistiu em colocar pasta de cimento dentro do tubo corrugado apoiado em uma mesa vibratória para adensar a amostra. Após a moldagem, o tubo foi colocado na sala com temperatura e umidade relativa controlados $\left(20 \pm 1^{\circ} \mathrm{C}\right.$ e $50 \pm 5 \%$, respectivamente), e deixado ensaiando por 14 dias. 
Foi utilizado um relógio comparador da Mitutoyo, com precisão de $0,001 \mathrm{~mm}$ e cursor de $12 \mathrm{~mm}$ para auxiliar as medições. A aquisição dos dados foi feita na plataforma LabView 2011 e hardware Arduino Uno. A Figura 3.8 apresenta a amostra e o suporte com o corpo de prova e o relógio comparador. A Figura 3.9 indica a disposição dos suportes para ensaio da retração autógena. Foram plotados gráficos de deformação versus tempo para avaliação da deformação desde os primeiros minutos até o final do ensaio.

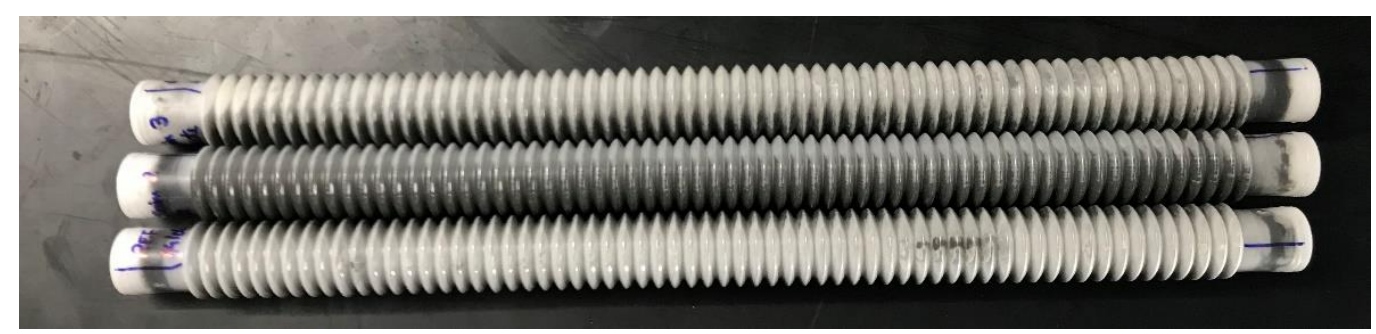

(a)

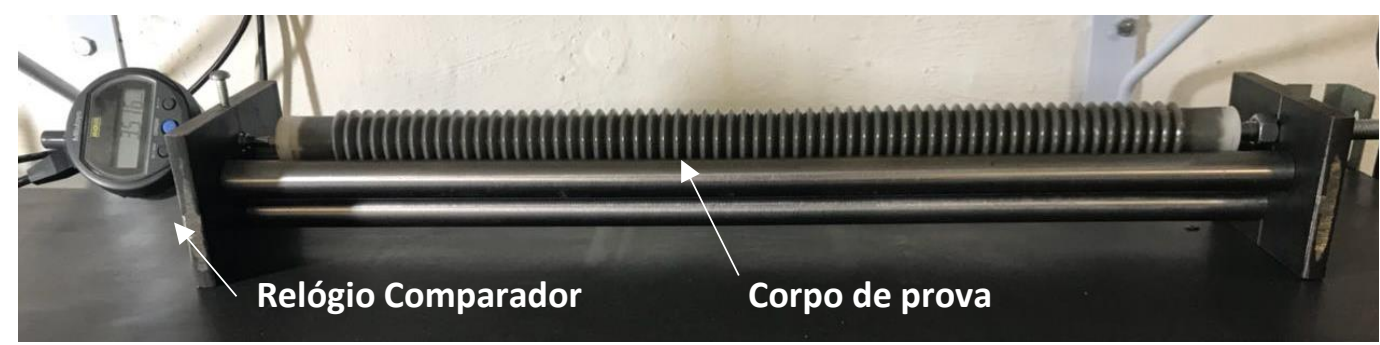

(b)

Figura 3.8 - Detalhe do ensaio de retração autógena: (a) corpos de prova ensaiados e (b) suporte com relógio comparador acoplado em uma das extremidades 


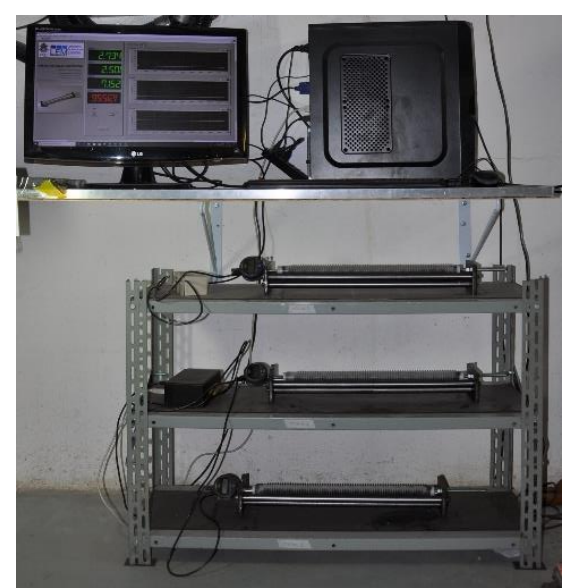

(a)

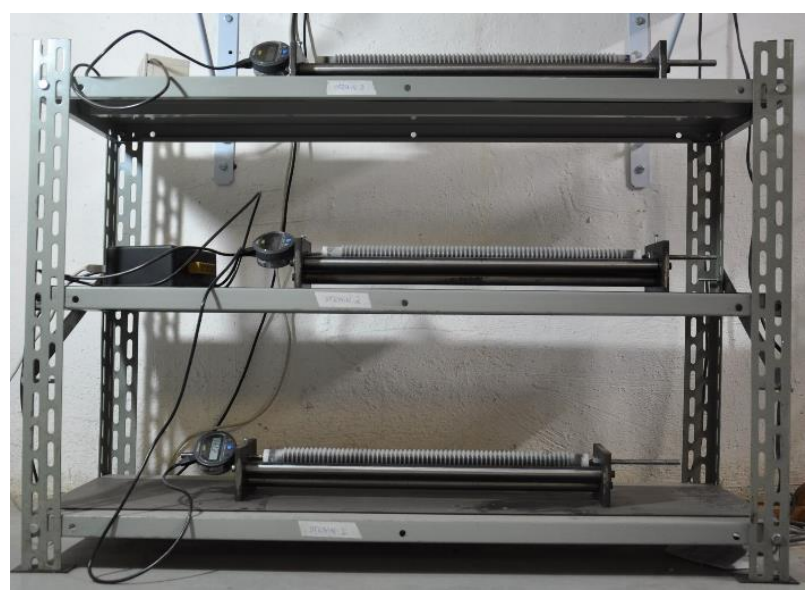

(b)

Figura 3.9 - Disposição dos suportes utilizados para leitura da variação de comprimento do ensaio de retração autógena

As fórmulas a seguir foram utilizadas para o cálculo da deformação por retração autógena, segundo a ASTM C1698 [86]:

$$
\begin{gathered}
L(t)=R(t)-2 \times L_{\text {tampão }} \\
\varepsilon_{\text {autógena }}=\frac{R(t)-R\left(t_{f s}\right)}{L\left(t_{f s}\right)} \times 10^{6}
\end{gathered}
$$

Onde,

$L(t)=$ comprimento do corpo de prova de pasta, $\mathrm{mm}$,

$R(t)=$ leitura do comprimento do corpo de prova no dilatometro, pelo relógio comparador, $\mathrm{mm}$,

$\varepsilon_{\text {autógena }}=$ deformação autógena, $\mu \mathrm{m} / \mathrm{m}$, e

$t_{f s}=$ tempo do início do ensaio, quando a primeira leitura do comprimento é realizada.

\subsubsection{Desenvolvimento da metodologia de ensaio}

O ensaio de retração autógena pelo método do tubo corrugado foi implementado no Laboratório de Estruturas e Materiais da PUC-Rio durante esta pesquisa. Considerando o grau de dificuldade na execução do ensaio, diversos testes foram realizados a fim de encontrar o melhor procedimento dentro do tempo disponível para o desenvolvimento da pesquisa. 
A leitura da variação de comprimento da amostra inicialmente foi feita com LVDT da Gefran, modelo PY-2-F-010-S01M e precisão de $\pm 0,3 \%$. A Figura 3.10 apresenta o sistema do suporte e LVDT. Neste primeiro teste foi observado que a precisão do LVDT não estava de acordo com o especificado na norma e, dessa forma, não tinha a precisão necessária para observar pequenas variações.

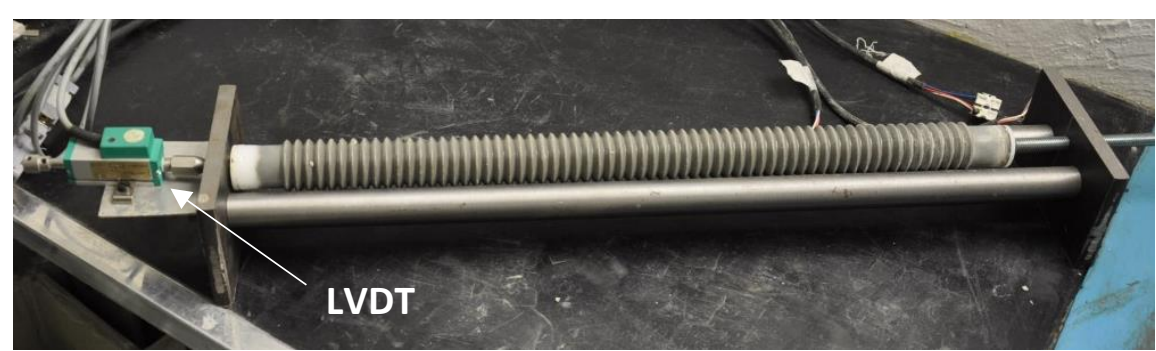

Figura 3.10 - Corpo de prova no tubo corrugado apoiado no suporte com LVDT a esquerda para leitura da variação de comprimento

O segundo teste realizado durante a implementação deste ensaio se deu com a substituição do LVDT por um relógio comparador da Mitutoyo, com precisão de 0,001mm, como recomendado pela ASTM 1698 [86]. A leitura inicialmente foi realizada de forma manual e a primeira leitura foi realizada após as primeiras 12 horas de idade. No entanto, a norma sugere que a primeira leitura seja feita no fim do tempo de pega, que, no caso desta pasta, era após 8 horas de idade.

Devido ao longo tempo de pega da mistura, não foi possível obter a primeira medida da variação de comprimento. Isso ocorreu porque a amostra foi moldada ao final do dia, tendo, portanto, a primeira leitura realizada 12 horas após a moldagem, perdendo assim a medida do fim do tempo de pega. Se a moldagem fosse feita de manhã cedo, a primeira leitura se daria ao final do dia, perdendo as primeiras 12 horas de ensaio após esta primeira medida. Dessa forma, foi constatado a inviabilidade da execução deste ensaio com leitura manual, uma vez que o ensaio foi realizado para as primeiras idades e que seria fundamental se ter as primeiras horas de ensaio medidas.

Utilizando um Arduino Uno, foi desenvolvido um sistema que permitiu a leitura automática da variação de comprimento das amostras. A descrição da programação desenvolvida se encontra no Apêndice A. Durante o ensaio, foi observado um espaço devido a retração do lado do corpo de prova oposto ao relógio comparador (lado direito na Figura 3.11), depois das primeiras horas de ensaio 
(antes do fim do tempo de pega). Foi feito uma correção manual, puxando o corpo de prova para o lado direito do suporte.

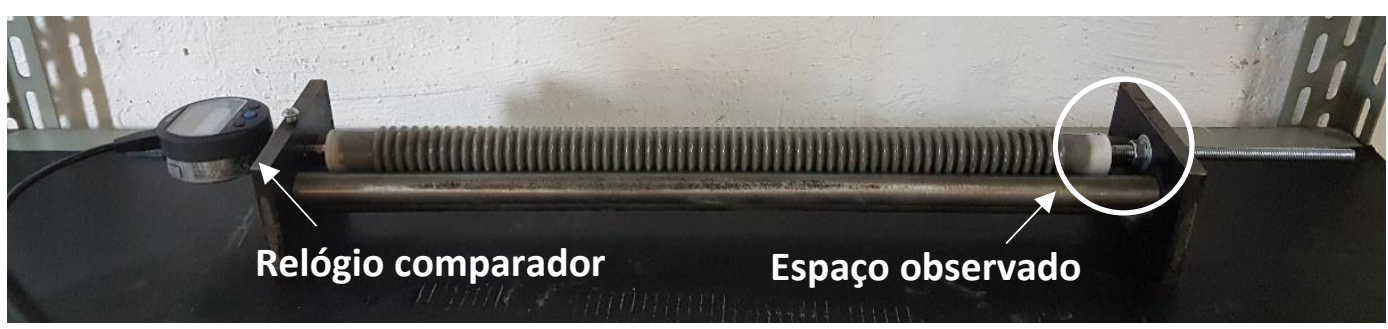

Figura 3.11 - Suporte do ensaio de retração autógena com relógio comparador localizado ao lado esquerdo

Ao se observar o suporte, foi constatado uma rugosidade nas hastes do apoio do suporte, que poderia estar influenciando na variação do comprimento do tubo. Dessa forma, as hastes foram lixadas e lubrificadas com óleo no intuito de reduzir o atrito entre elas e o corpo de prova. A Figura 3.12 apresenta o suporte antes e depois do processo de lixar. No entanto, durante o ensaio foi observado que o espaço do lado direito do suporte continuou aparecendo nos ensaios, sendo necessário fazer o ajuste manual nas primeiras horas.

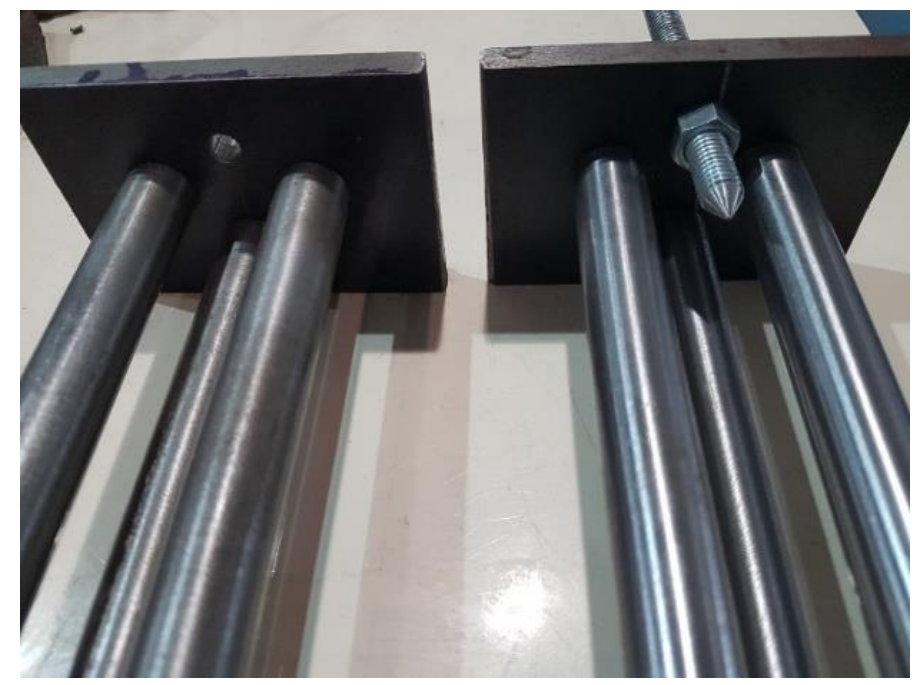

Figura 3.12 - Suporte do ensaio do tubo corrugado: hastes antes (a esquerda) e depois (a direita) de serem lixadas

A última metodologia testada foi colar com araldite o lado direito do tubo corrugado ensaiado no suporte (lado oposto ao relógio comparador, como ilustrado na Figura 3.13). Foi observado que o comportamento e os valores de deformação do corpo de prova foram semelhantes aos do ensaio anterior, mas sem o 
aparecimento do espaço no lado direito durante as primeiras horas de ensaio. Dessa forma foi adotada esta metodologia para os ensaios de retração autógena pelo método do tubo corrugado realizado nesta pesquisa.

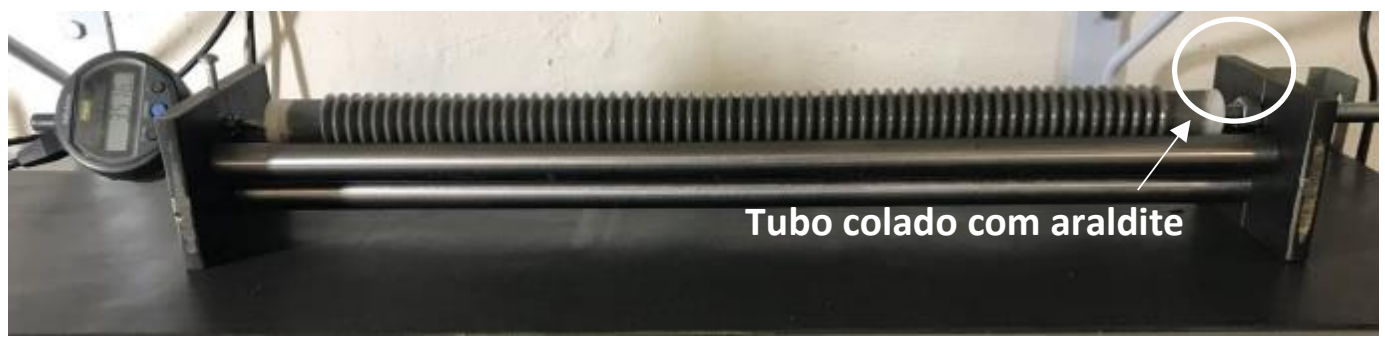

Figura 3.13 - Detalhe do tubo corrugado com o lado direito colado com araldite no suporte utilizado para o ensaio

O sistema utilizando leitura automática pelo Arduino Uno tinha como limitante a leitura de apenas um relógio por vez. Foi então desenvolvido um sistema mais elaborado, integrando os Arduinos Uno e o programa de aquisição de dados LabView 2011 - a descrição da programação no LabView também está apresentada no Apêndice A, a fim de possibilitar leituras simultâneas de mais de um relógio comparador em um mesmo computador. No presente trabalho, o número de ensaios realizados ao mesmo tempo foi de 3 . Esse sistema possibilitou a redução no tempo total dos ensaios na pesquisa.

\subsubsection{Retração por secagem}

\subsubsection{Método linear}

Os ensaios para avaliação da deformação por retração por secagem livre foram realizados segundo a ASTM C490 [88]. Foram moldados 5 prismas com 285 mm de comprimento e $25 \times 25 \mathrm{~mm}$ de área da seção transversal para cada mistura. A moldagem foi realizada na mesma sala da realização dos ensaios, com temperatura e umidade relativa controlada de $20 \pm 1^{\circ} \mathrm{C}$ e $50 \pm 5 \%$, respectivamente. Para auxiliar a medição, os prismas foram moldados com pinos côncavos nas duas extremidades. A primeira medida foi realizada logo após a desmoldagem dos corpos de prova. A Figura 3.15 apresenta os moldes e os corpos de prova da retração por secagem livre. 


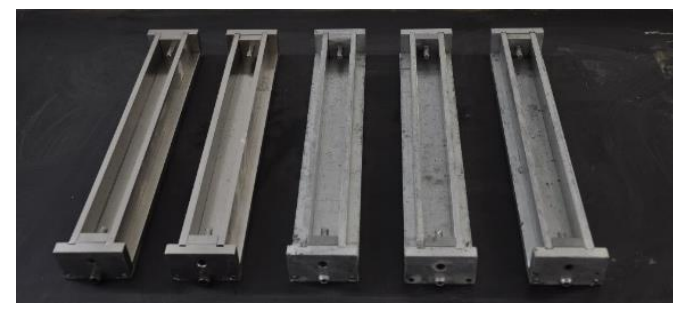

(a)

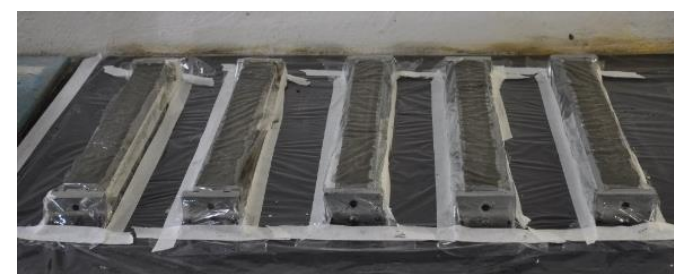

(b)

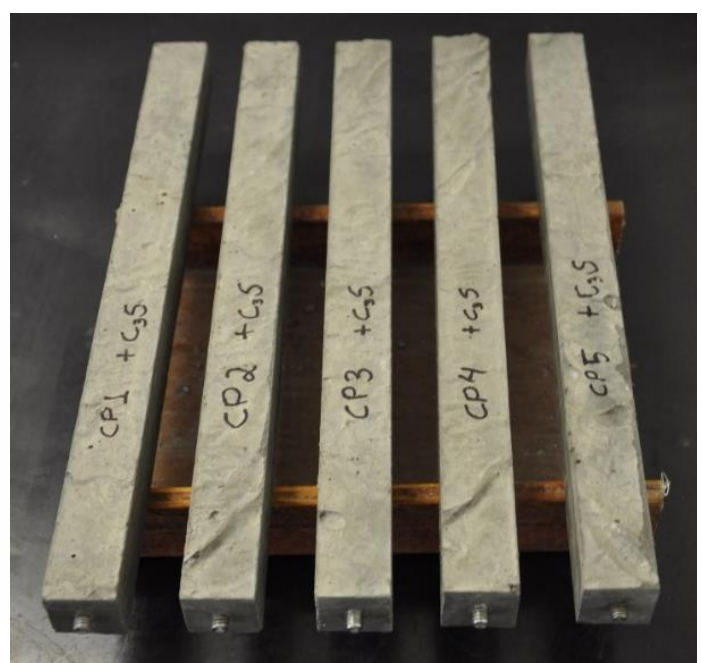

(c)

Figura 3.14 - Etapas do ensaio de retração livre: (a) preparação dos moldes, (b) moldagem dos corpos de prova e (c) corpos de prova ensaiados

As leituras foram realizadas de hora em hora no primeiro dia (começando logo depois de desmoldar) e de duas em duas horas do segundo ao oitavo dia (exceto finais de semana), durante o horário de funcionamento do laboratório. Além disso, as amostras foram pesadas a cada leitura para posterior análise da influência da perda de massa na deformação por secagem. Um relógio comparador da Digimess, com precisão de $0,001 \mathrm{~mm}$ e cursor de $12 \mathrm{~mm}$, foi acoplado na parte superior do suporte para a efetuação da leitura do comprimento dos prismas. A Figura 3.16 apresenta o suporte utilizado para realização dessas medições, e a Figura 3.17 apresenta a barra de referência utilizada para calibrar o relógio a cada medição. Foram plotados gráficos de deformação versus tempo para comparação entre as diferentes misturas desta pesquisa. 


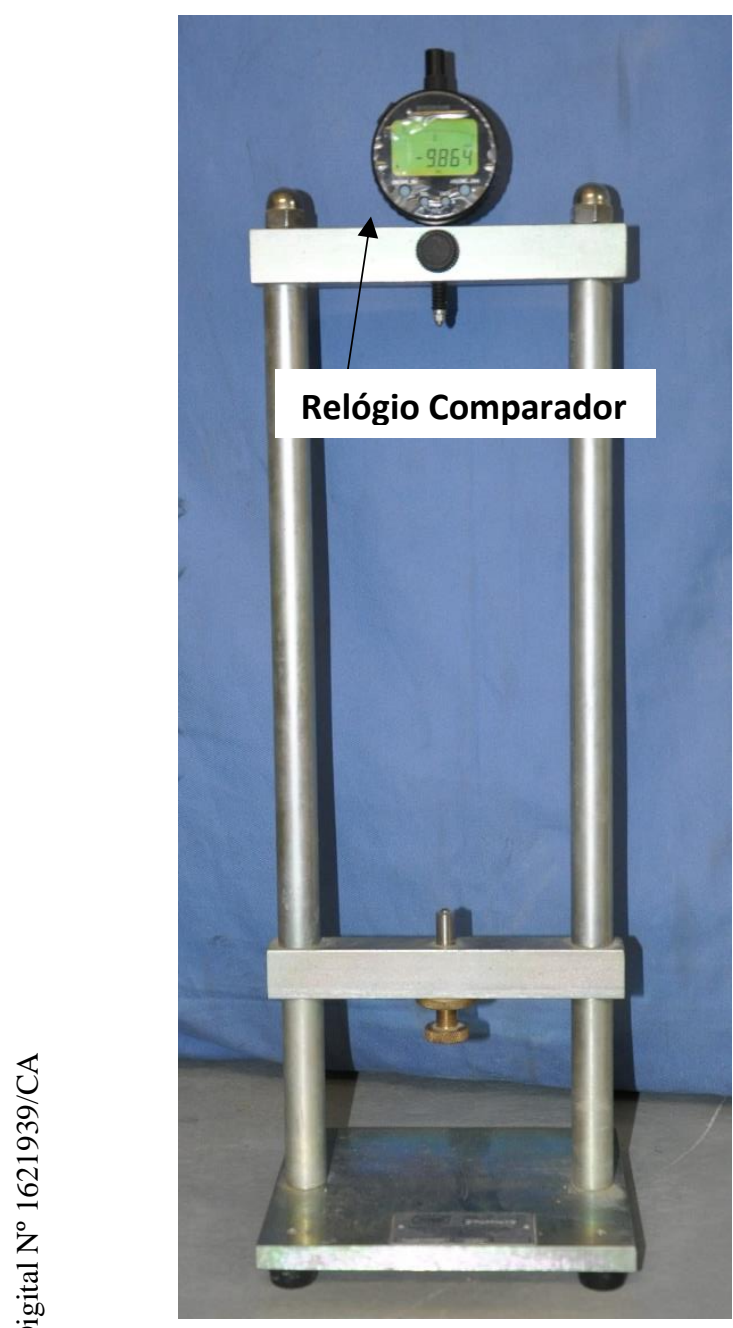

(a)

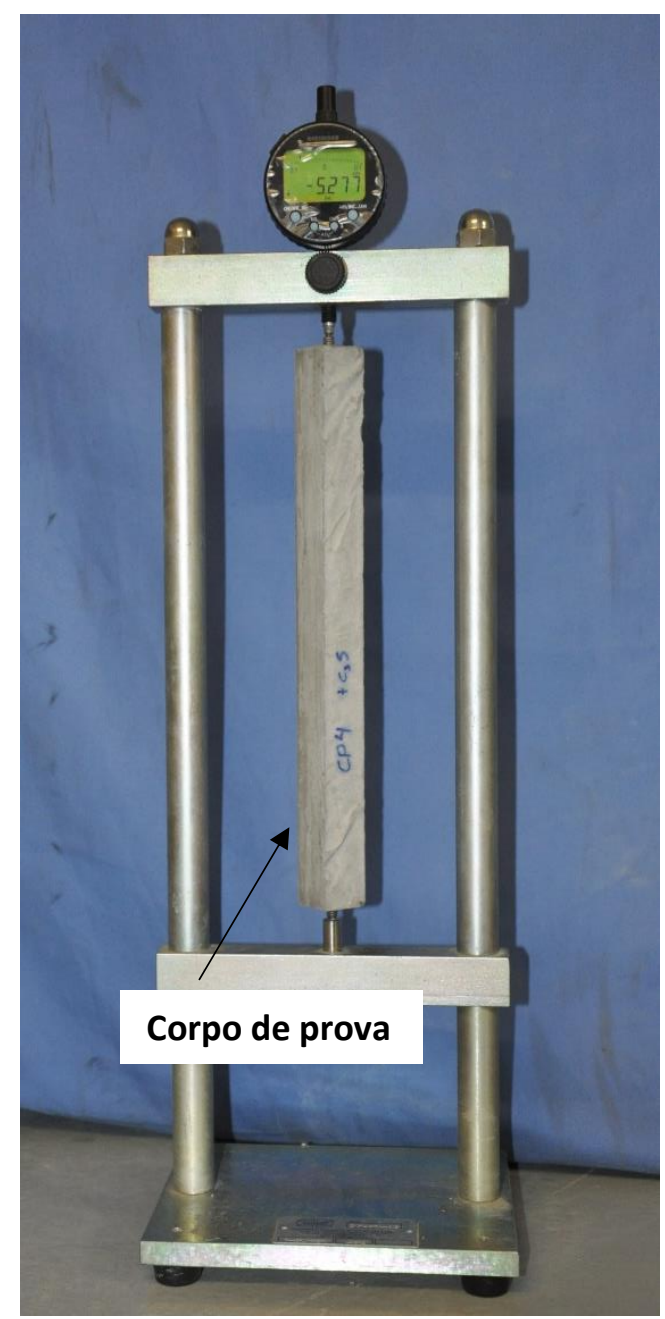

(b)

Figura 3.15 - Pórtico utilizado para leitura da variação de comprimento do ensaio de retração por secagem livre (a) e com corpo de prova (b)

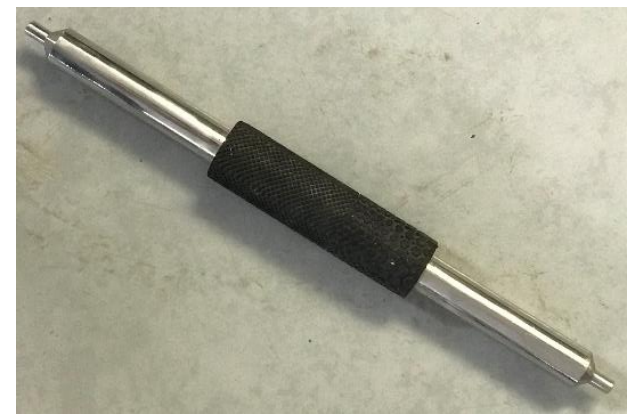

Figura 3.16 - Barra de referência utilizada no ensaio de retração por secagem livre

O cálculo da variação de comprimento dos prismas foi feito de acordo com a ASTM C490 [88], da seguinte forma: 


$$
L=\frac{\left(L_{j}-L_{i}\right)}{G} \times 100
$$

Onde,

$L=$ mudança no comprimento na idade $\mathrm{j}, \%$,

$L_{j}=$ leitura comparativa do corpo de prova na idade $\mathrm{j}$ menos leitura comparativa da barra de referência na idade $\mathrm{j}, \mathrm{mm}$,

$L_{i}=$ leitura inicial do corpo de prova menos leitura da barra de referência no mesmo instante, $\mathrm{mm}$, e

$G=$ leitura nominal da barra de referência, estabelecida em 250mm.

\subsubsection{Método do anel de aço}

Os ensaios para avaliação da abertura de fissura devido à retração por secagem com restrição foram realizados segundo a ASTM C1581 [89]. Foi moldado um anel para cada mistura e a abertura de fissura foi medida até o sétimo dia de idade de cada amostra. $\mathrm{O}$ anel de aço tem $31 \mathrm{~cm}$ de diâmetro interno, e o anel de concreto tem $32,6 \mathrm{~cm}$ de diâmetro interno e 40,2 cm de diâmetro externo. A Figura 3.18 apresenta os detalhes do molde do anel. Foram colados 3 extensômetros tipo PA-06-201BA-120L, F.S. 2,17 equidistantes na parte interna do anel de aço interno para a leitura da deformação.

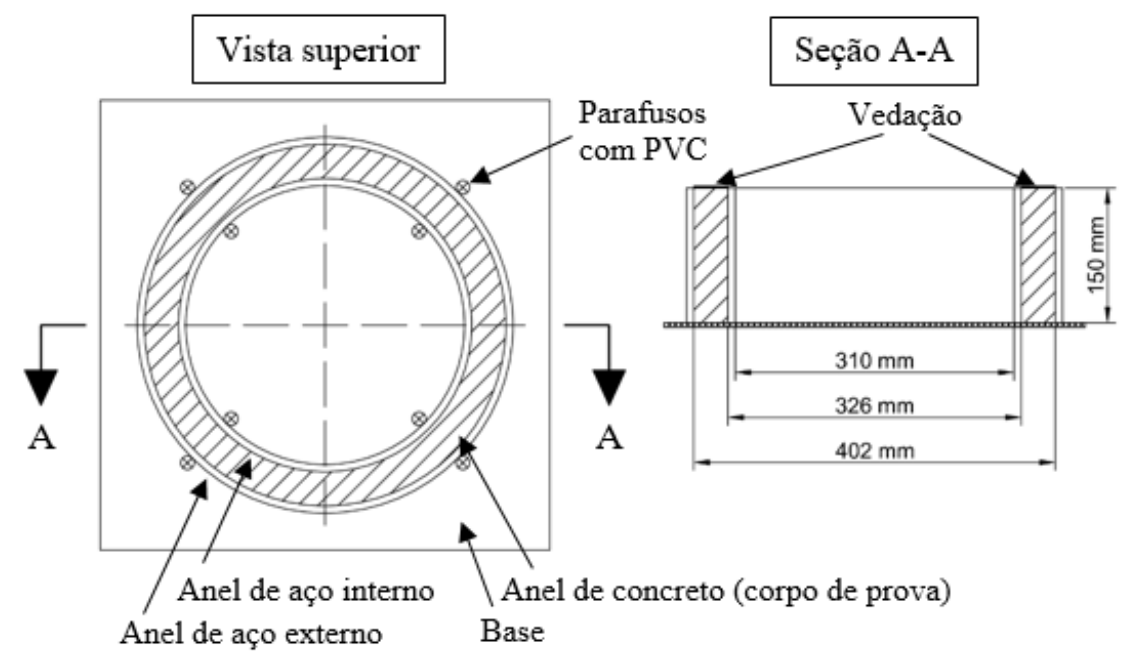

Figura 3.17 - Descrição detalhada do molde do anel, adaptado de ASTM C1581 [89]

Após a moldagem, o anel foi selado com papel filme na parte superior, para evitar perda de água durante a cura. Após o desmolde, em que o anel de aço externo 
foi retirado, uma fita de alumínio foi colocada na parte superior do anel de pasta de cimento, permitindo apenas a perda de água pela lateral externa da amostra. Todos os ensaios foram realizados em sala com temperatura e umidade relativa controlada de $20 \pm 1{ }^{\circ} \mathrm{C}$ e $50 \pm 5 \%$, respectivamente. A Figura 3.19 apresenta o molde antes da moldagem e durante o ensaio.

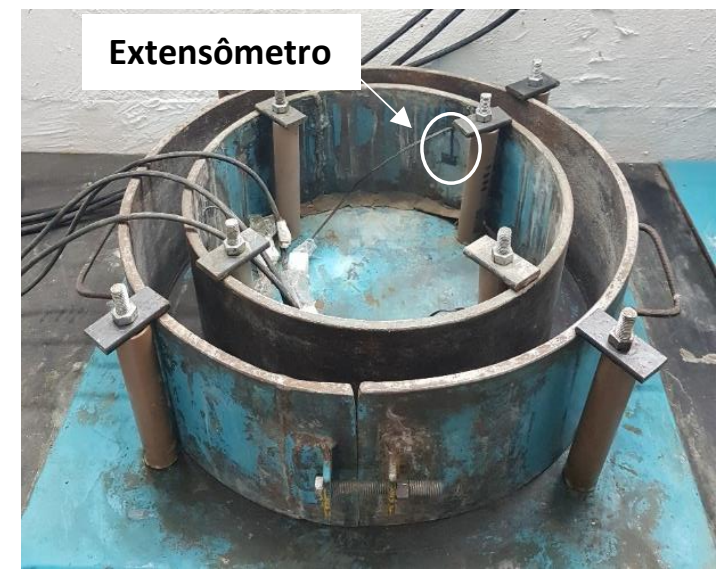

(a)

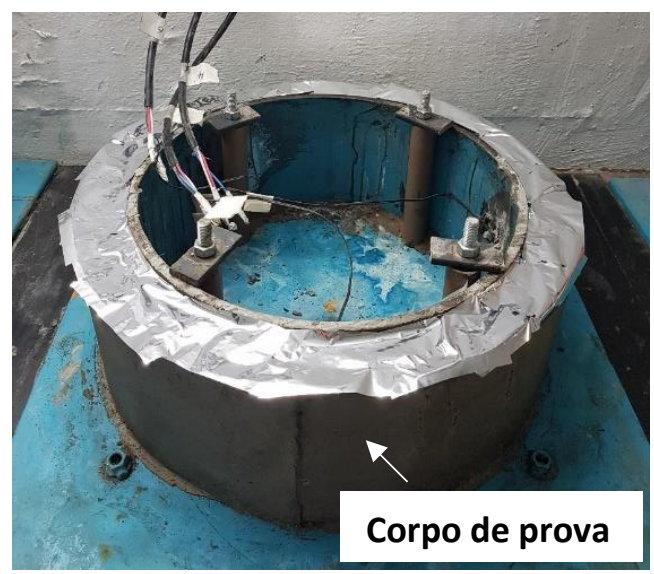

(b)

Figura 3.18 - Detalhe do ensaio de retração com restrição: (a) preparação do molde e (b) corpo de prova durante o ensaio (após retirada do anel de aço externo).

A abertura das fissuras foi acompanhada e as medições realizadas duas vezes ao dia com auxílio do Microscópio Digital Portátil Pro, da Celestron, a partir do momento em que ocorreram as fissuras. A Figura 3.20 apresenta o anel de pasta de cimento fissurado (a), microscópio utilizado (b), e o detalhe da fissura vista por meio do microscópio (c). 


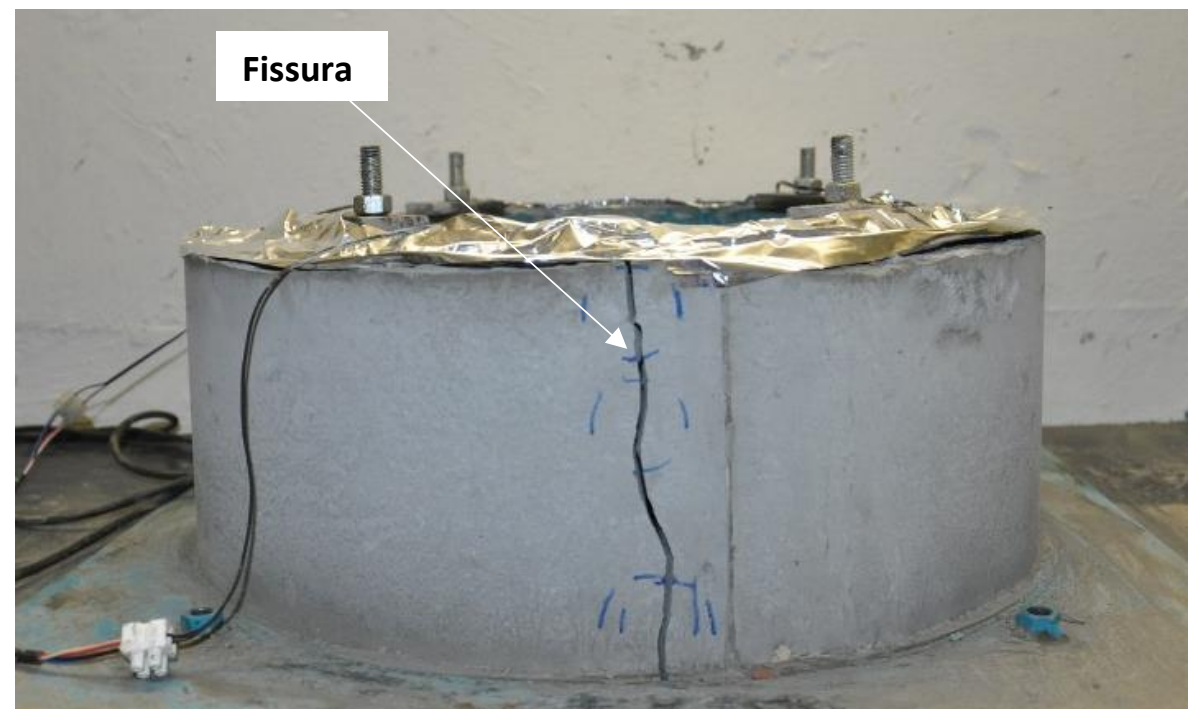

(a)

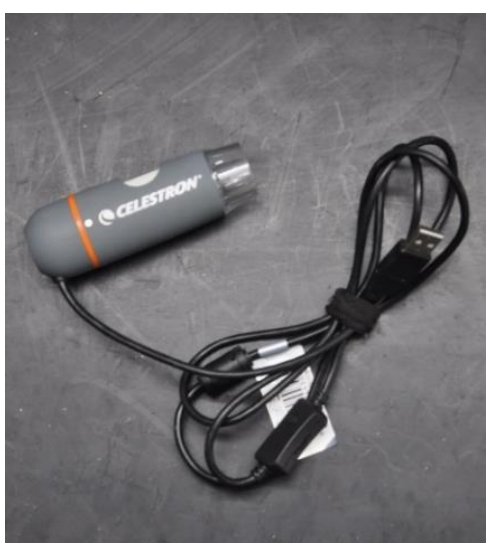

(b)

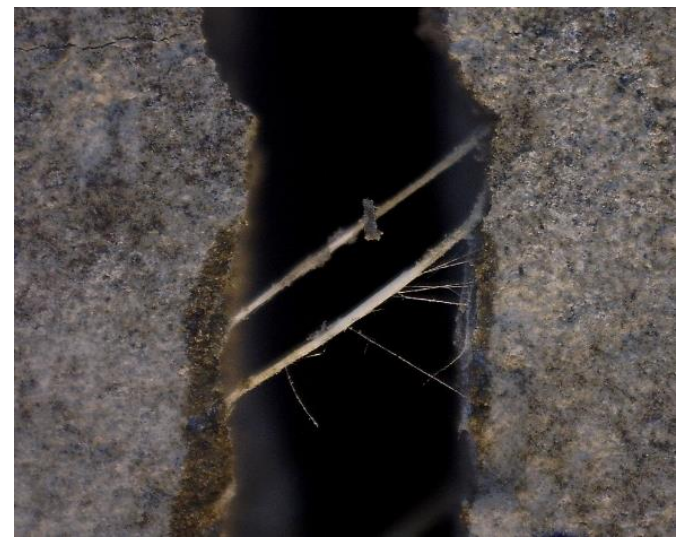

(c)

Figura 3.19 - Acompanhamento da abertura de fissura: (a) anel de pasta de cimento fissurado, (b) Microscópio Digital Portátil e (c) detalhe da fissura da pasta com adição de $1,2 \mathrm{~kg} / \mathrm{m}^{3}$ de curauá observada pelo microscópio

A leitura da deformação dos 3 extensômetros foi aquisitada pelo software Catman Easy V4.1.2 e hardware da HBM modelo MX1615. Essa leitura foi iniciada logo antes da moldagem e realizada a cada 50 segundos. A Figura 3.21 apresenta o hardware utilizado e a interface do programa de aquisição dos dados. 


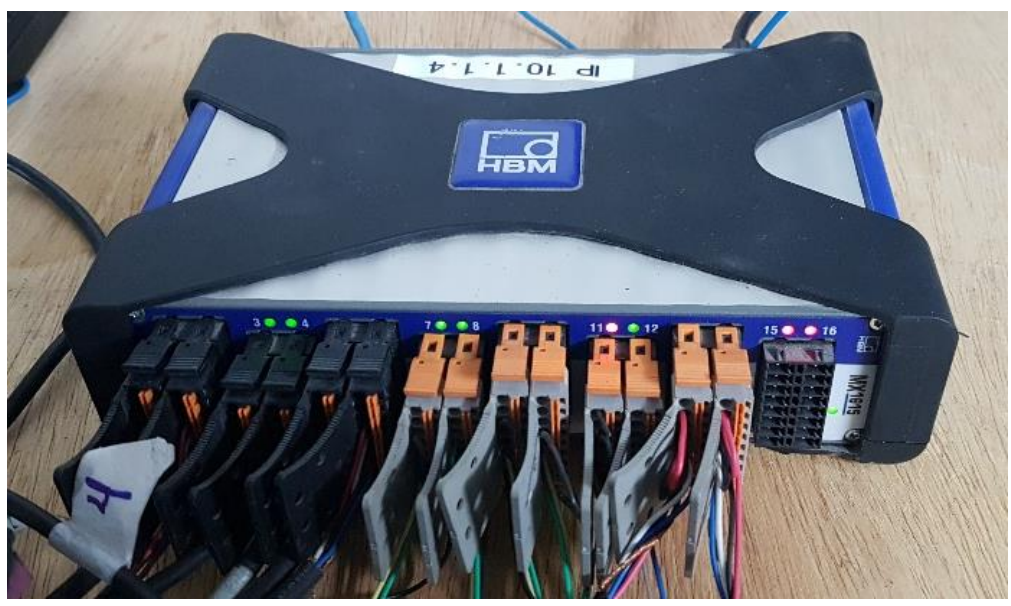

(a)
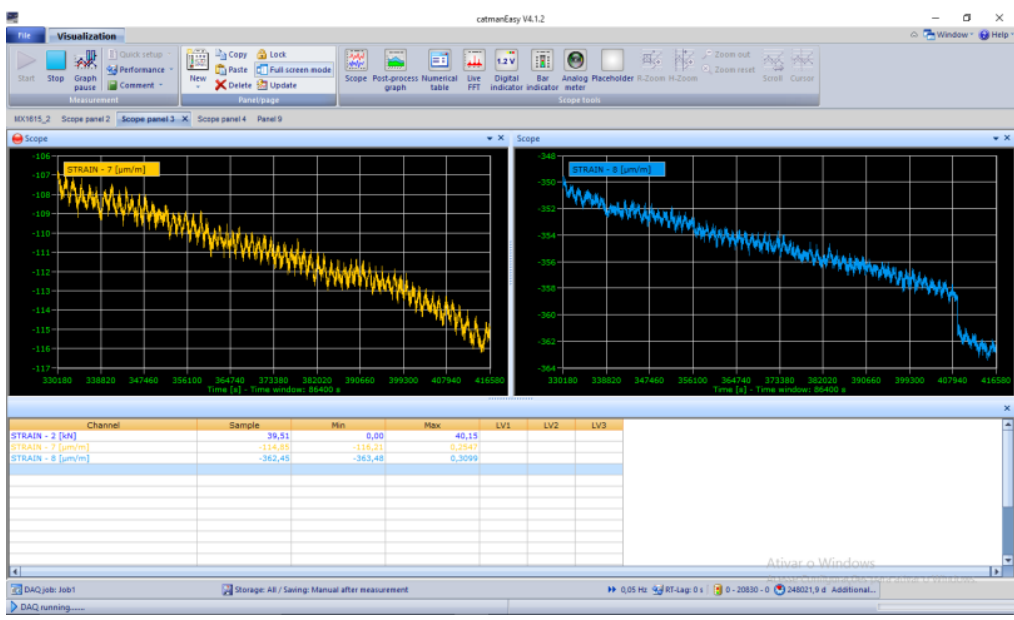

(b)

Figura 3.20 - Leitura das deformações do ensaio retração com restrição: (a) aparelho da HBM para aquisição dos dados e (b) Interface do software Catman Easy

\subsubsection{Compressão}

Os ensaios de compressão foram realizados de acordo com a NBR7215 [90] na pasta de referência e nas demais pastas com 3 dias de idade. Foram moldados 6 corpos de prova cilíndricos com altura de $10 \mathrm{~mm}$ e diâmetro de $50 \mathrm{~mm}$ com a finalidade de se obter a média da resistência máxima das amostras na idade desejada. A Figura 3.22 apresenta os moldes cilíndricos e as amostras. 


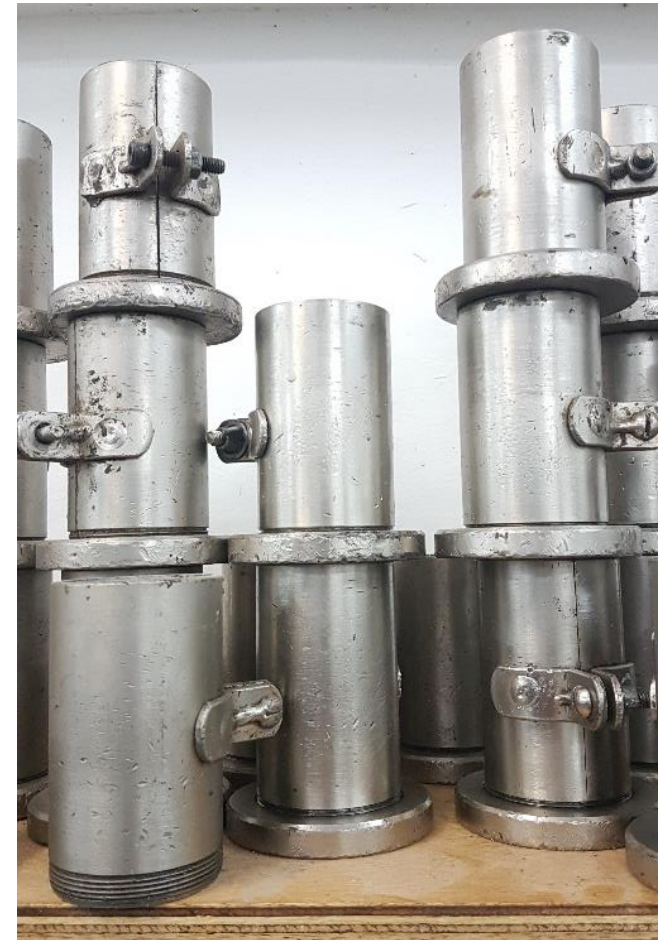

(a)

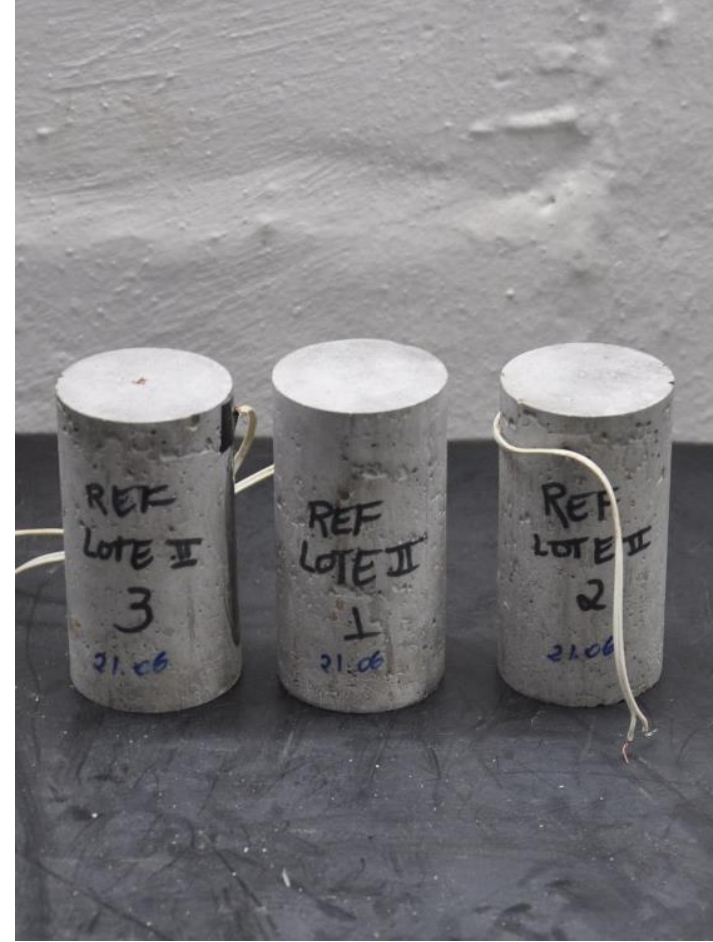

(b)

Figura 3.21 - Moldagem dos corpos de prova: (a) preparação dos moldes cilíndricos e (b) detalhe dos corpos de prova

Os corpos de prova foram ensaiados em uma máquina servo hidráulica MTS 810 com capacidade de carga de $500 \mathrm{kN}$ e com controle por deslocamento a taxa de $0,5 \mathrm{~mm} / \mathrm{min}$ (Figura 3.23). Os resultados dos valores médios da resistência à compressão aos 3 dias de idade de cada mistura estão apresentados na Figura 3.24 e na Tabela 3.6. 


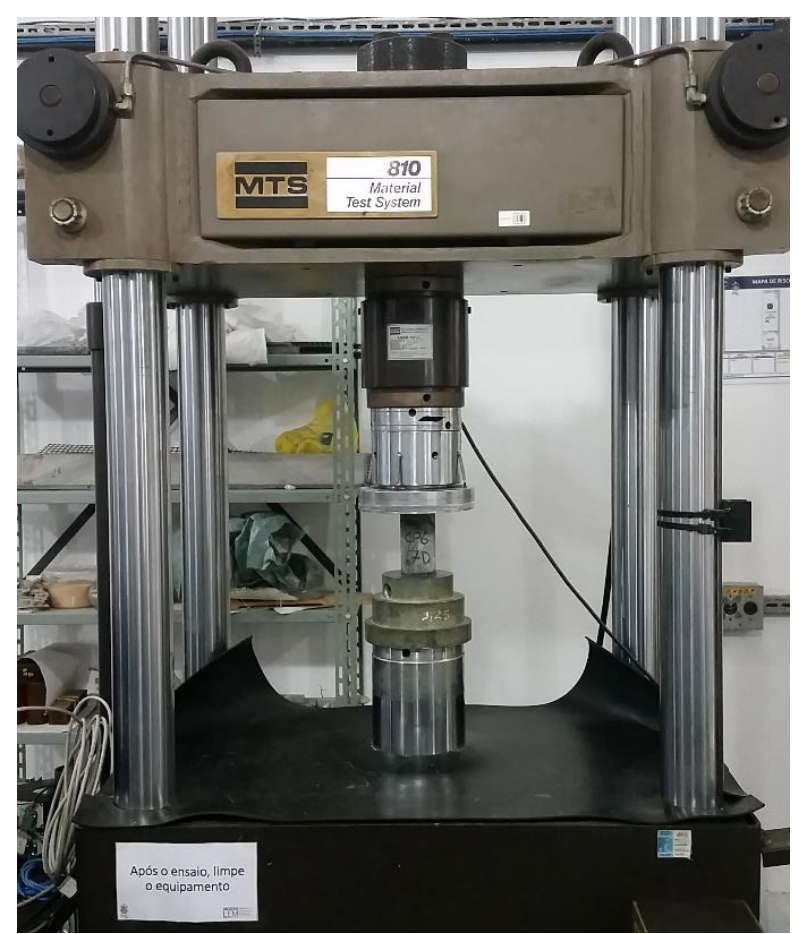

(a)

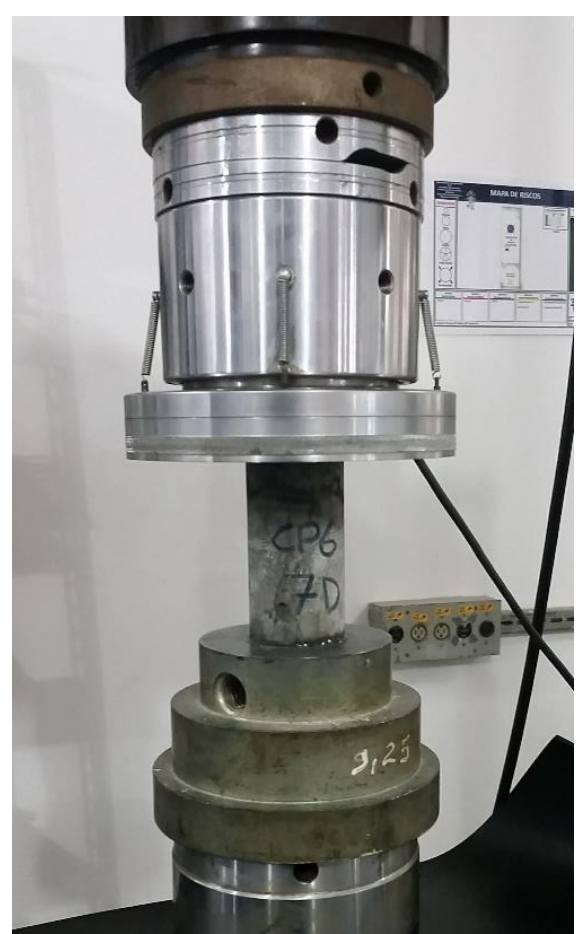

(b)

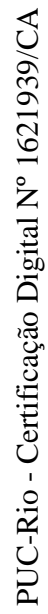

Figura 3.22 - Ensaio de compressão: (a) equipamento utilizado e (b) detalhe do corpo de prova sendo ensaiado

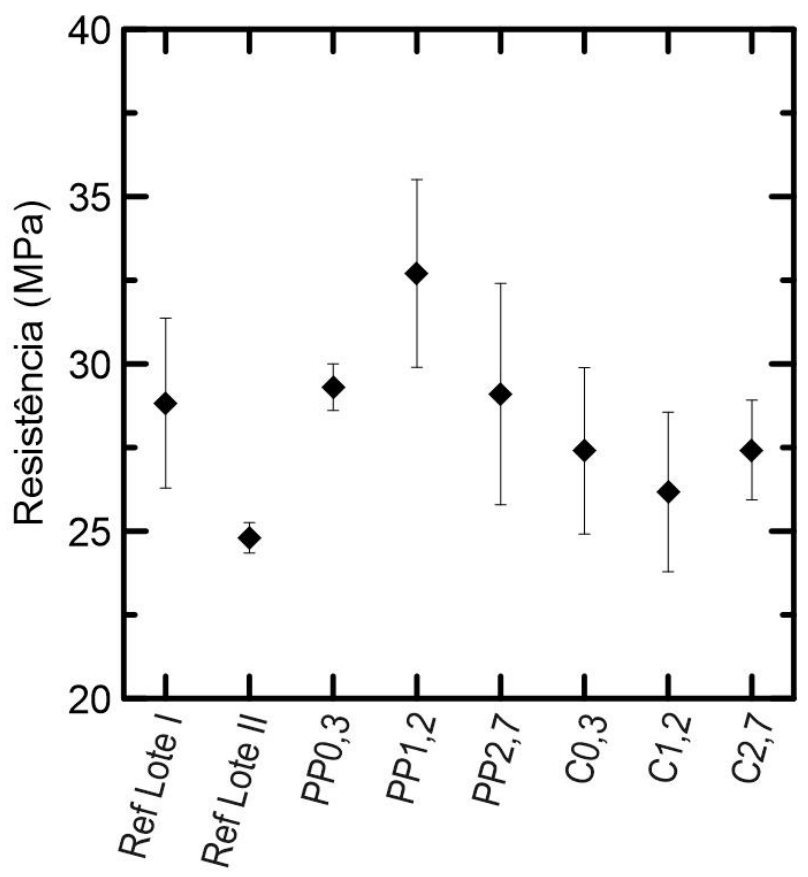

Figura 3.23 - Valores médios de resistência máxima a compressão das misturas aos 3 dias de idade 
Tabela 3.6 - Valores médios de resistência à compressão aos 3 dias de idade das pastas de cimento com e sem reforço fibroso

\begin{tabular}{lcc}
\hline $\begin{array}{c}\text { Valores em } \\
\text { kN }\end{array}$ & Média & Desvio Padrão, D.P. \\
\hline Ref_LI53 & 56,60 & 4,99 \\
Ref_LII65 & 48,70 & 0,89 \\
C0,3 & 53,80 & 4,88 \\
C1,2 & 51,39 & 4,68 \\
C2,7 & 53,85 & 2,92 \\
PP0,3 & 57,53 & 1,37 \\
PP1,2 & 64,21 & 5,51 \\
PP2,7 & 57,13 & 6,50 \\
\hline
\end{tabular}

\subsubsection{Fluência}

Os ensaios para avaliação da deformação devido à fluência a compressão foram realizados baseados na norma ASTM C512 [91]. Esta norma é definida para ensaios de fluência em corpos de prova de concreto. No entanto, devido à falta de normas estabelecidas para esse tipo de ensaio em pastas de cimento, e considerando que o comportamento da pasta seja similar, mas em diferente escala, ao comportamento do concreto sob as mesmas condições, optou-se por seguir as recomendações apresentadas na norma, com devidas adaptações.

Os três corpos de prova foram colocados de forma que ficassem enfileirados um em cima do outro. Um disco de aço de espessura de $10 \mathrm{~mm}$ e diâmetro de $50 \mathrm{~mm}$ foi colocado entre os corpos de prova (Figura 3.25). Em seguida, os corpos de prova foram posicionados em cima de uma rótula, utilizada para corrigir possíveis desníveis do pórtico e melhor distribuir a carga aplicada. Uma célula de carga Gefran TH-KM3D 2130X, com capacidade para $30 \mathrm{kN}$ foi posicionada abaixo da rótula, para leitura da carga aplicada. A Figura 3.26 apresenta o pórtico do ensaio de fluência e o esquema descrito acima. 


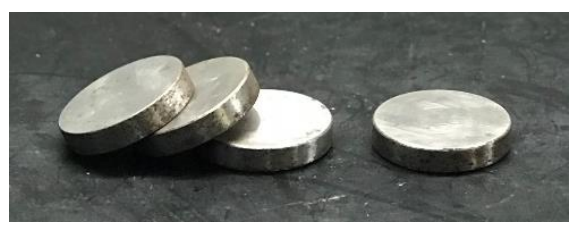

Figura 3.24 - Disco de aço colocado entre os corpos de prova para o ensaio de fluência básica

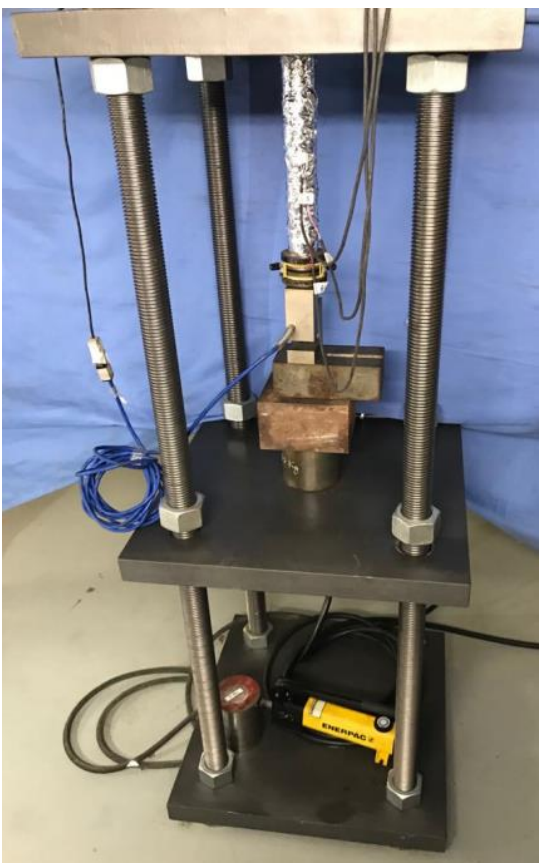

(a)

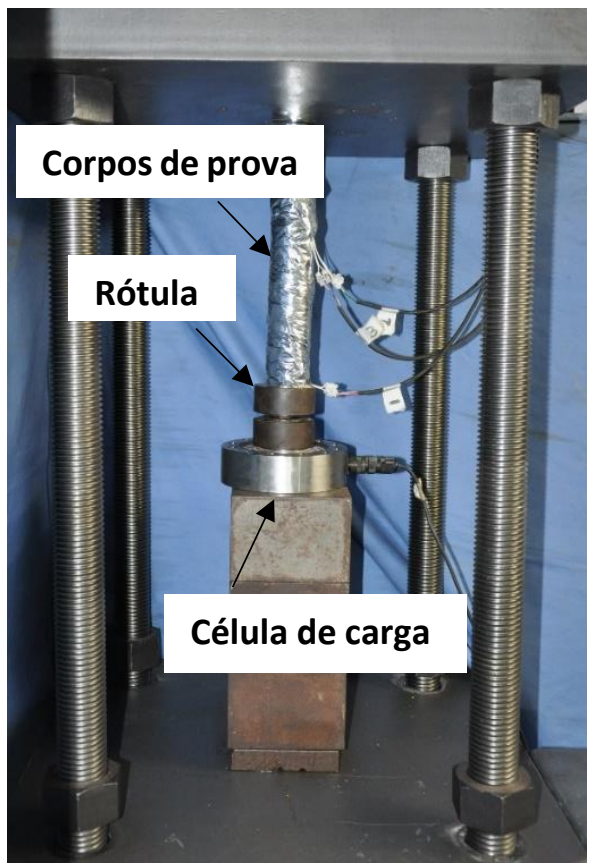

(b)

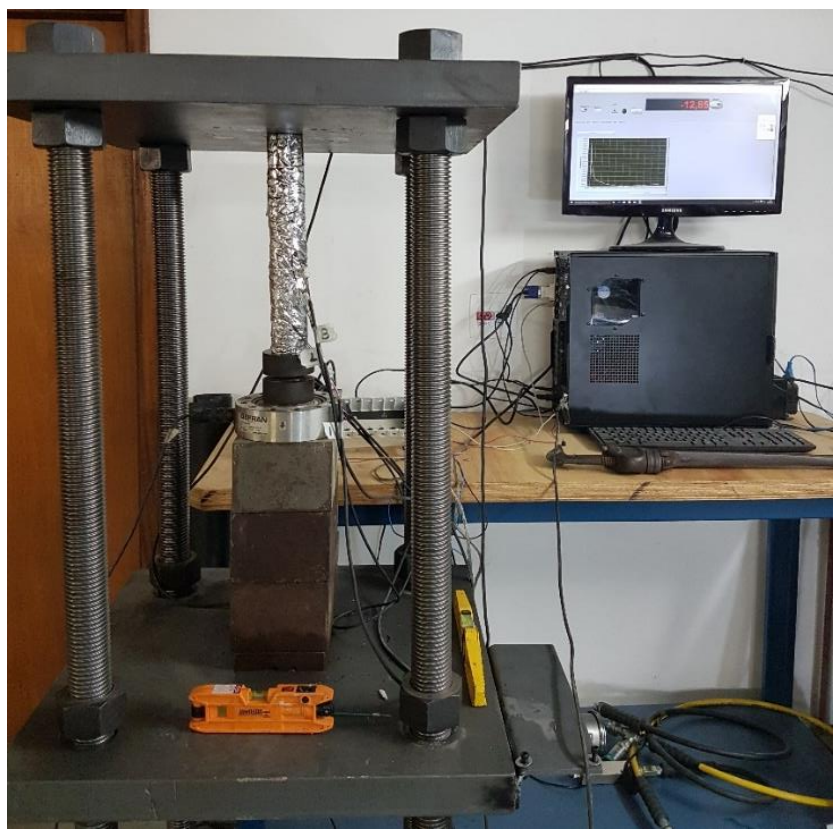

(c)

Figura 3.25 - Ensaio de fluência: (a) Pórtico utilizado no ensaio de fluência básica a compressão, (b) disposição dos corpos de prova vedados com a rótula e a célula de carga e (c) visão geral do sistema 
Esta pesquisa utilizou um sistema manual de aplicação de carga. O incremento de carga se deu através de torque aplicado nas roscas da parte debaixo da mesa do pórtico, como ilustrado na Figura 3.27. Uma chave de grifo foi utilizada para a aplicação desse torque (Figura 3.28). Esse ajuste na carga foi realizado durante os dias úteis, com eventuais ajustes aos finais de semana. Foram plotados gráficos de força versus tempo e deformação versus tempo para discussão do comportamento de cada mistura sob carga do terceiro ao décimo dia de idade dos corpos de prova. O gráfico da Figura 3.29 apresenta as curvas de deformação e força durante o ensaio. É possível relacionar a descontinuidade da deformação e o incremento de carga de ajuste do sistema.

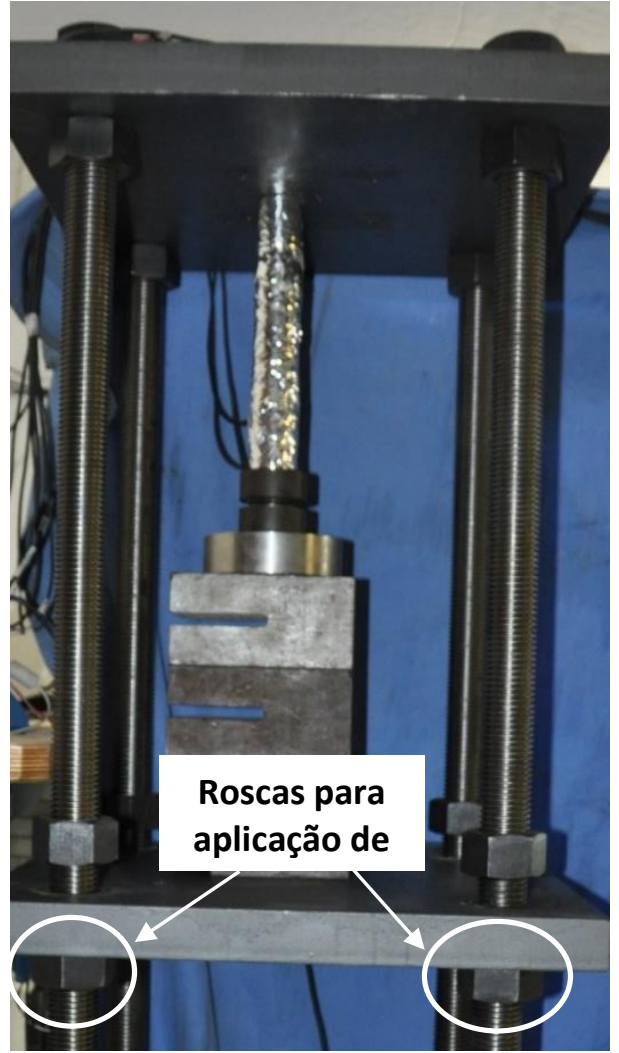

Figura 3.26 - Ilustração da aplicação de carga nas roscas inferiores do pórtico

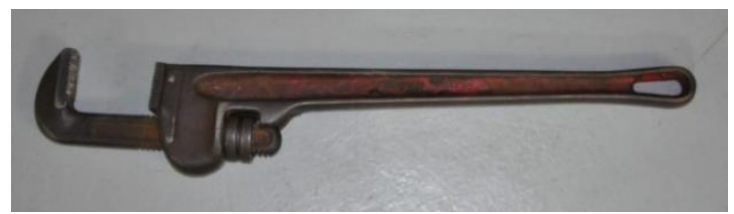

Figura 3.27 - Chave de grifo utilizada para aplicação do torque 


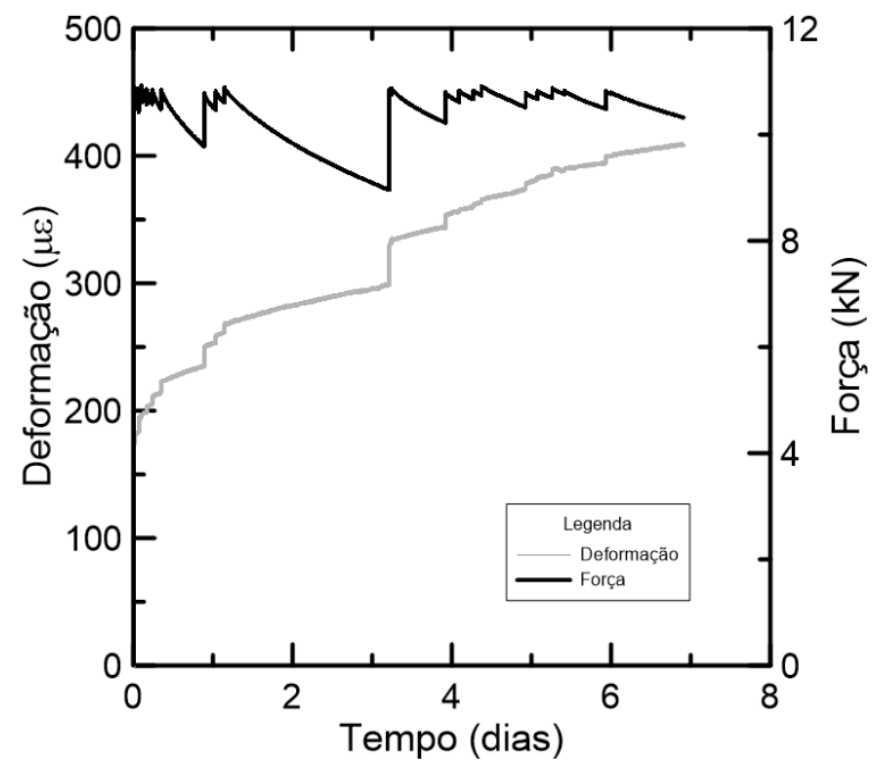

Figura 3.28 - Gráfico ilustrativo do sistema de aplicação de carga por meio de torque nas roscas da mesa do pórtico

O ensaio consistiu na aplicação de $20 \%$ da carga máxima à compressão resistida pelo corpo de prova aos 3 dias de idade. O período de aplicação dessa carga foi de 7 dias. No total, 3 amostras foram moldadas e ensaiadas para cada mistura. Após o desmolde e a cura em água com cal, os corpos de prova foram deixados secando por $24 \mathrm{~h}$ até a hora do ensaio. Os ensaios foram realizados em sala com temperatura e umidade relativa controlada de $20 \pm 1^{\circ} \mathrm{C}$ e $50 \pm 5 \%$, respectivamente. Foi colado 1 extensômetro tipo PA-06-201BA-120L, F.S. 2,17 em cada corpo de prova para leitura da deformação. A carga e a deformação foram lidas através do programa de aquisição de dados LabView 2011 e do hardware da Nationals Instruments modelo NI cDAQ-9172 (Figura 3.30). 


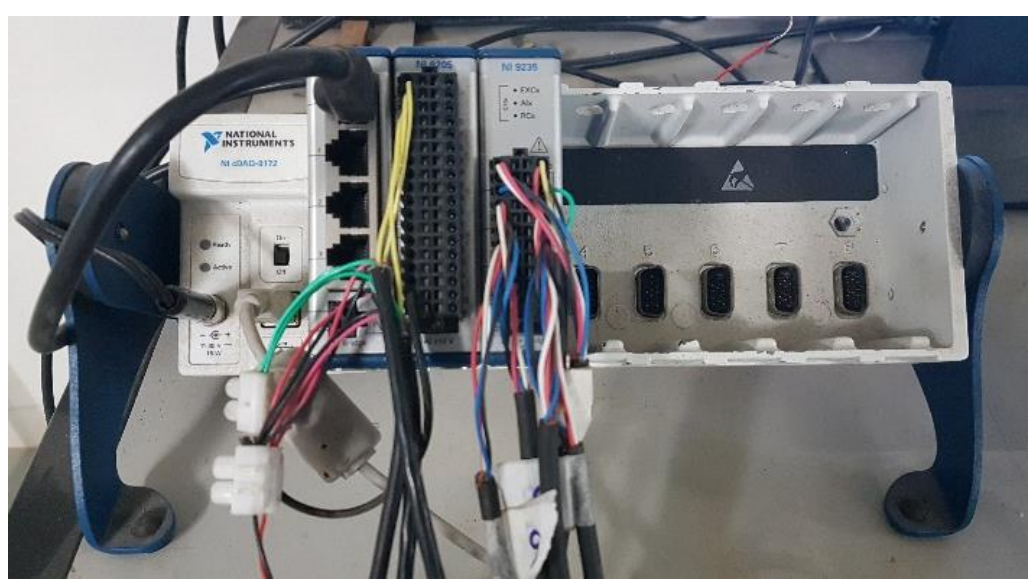

(a)

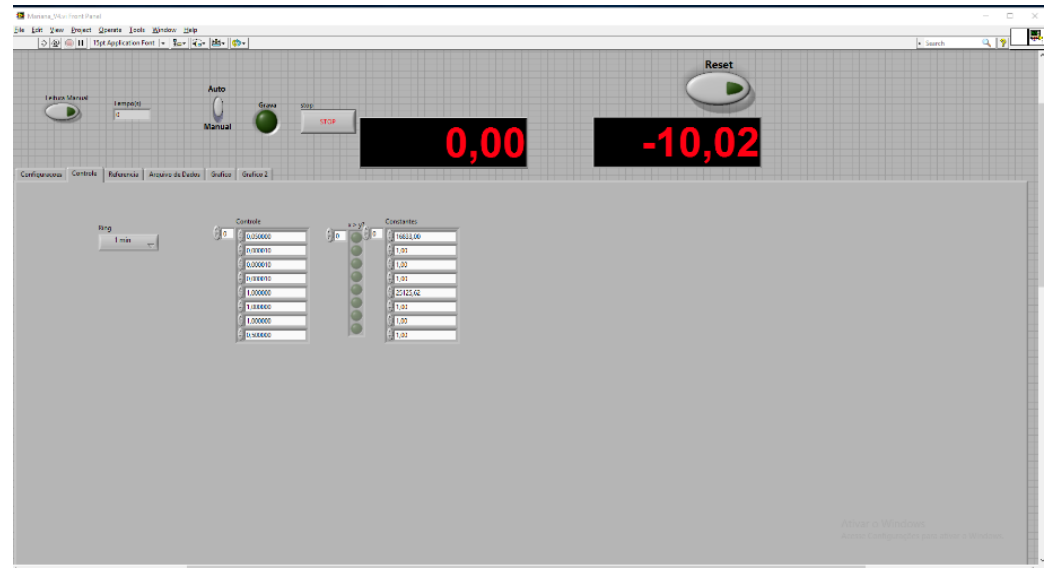

(b)

Figura 3.29 - Leitura das deformações do ensaio de fluência: (a) Aparelho de aquisição de dados da National Instruments e (b) Interface do programa LabView 


\section{Discussão dos resultados}

O capítulo apresenta os resultados experimentais dos ensaios descritos no programa experimental e suas respectivas análises. As discussões sobre o comportamento de cada mistura para cada tipo de ensaio são feitas apresentando, quando existente, comparações com resultados de outros autores. No entanto, devese levar em consideração que diversos fatores, incluindo diferenças nos materiais utilizados, na preparação das amostras e nas condições de ensaios, também influenciam os ensaios descritos nesta pesquisa.

No ensaio de retração autógena foram variados os lotes dos cimentos e os teores de curauá. Para os ensaios de retração por secagem livre e com restrição foram variados os teores de curauá e de polipropileno. E nos ensaios de fluência básica a compressão, as variáveis foram os lotes dos cimentos e os teores de fibras de curauá e polipropileno. A Figura 4.1 resume os componentes que foram variados em cada ensaio.
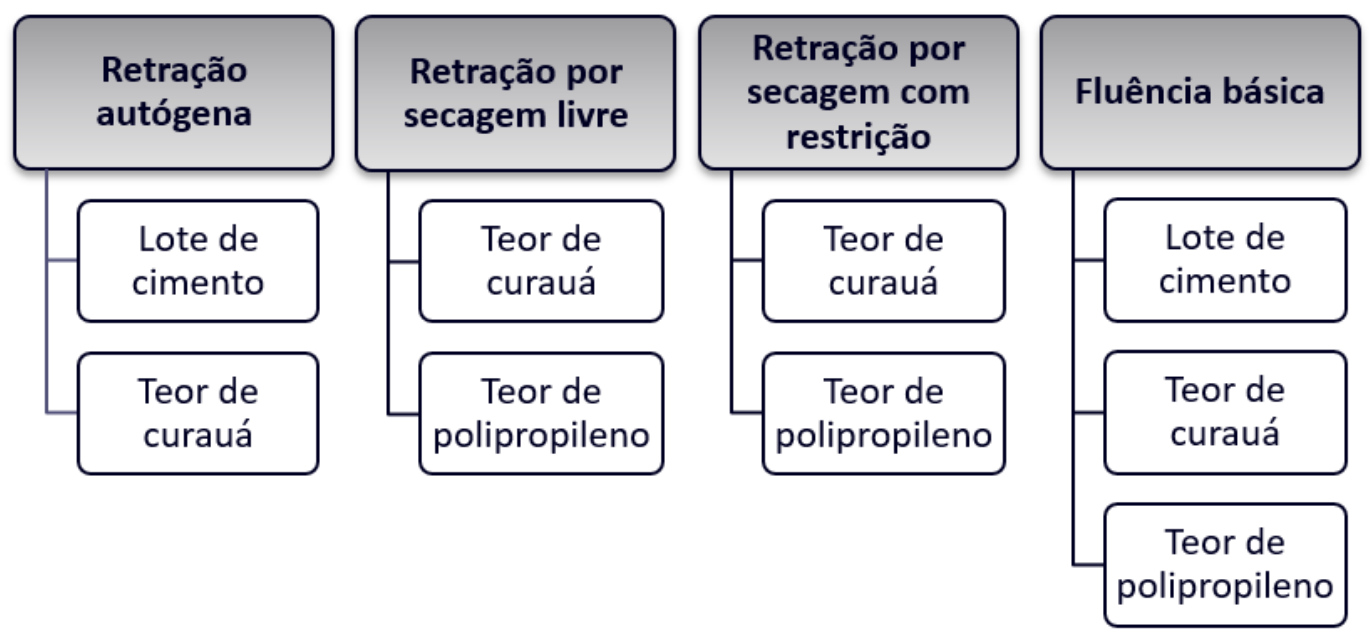

Figura 4.1 - Resumo das variáveis dos ensaios de retração autógena, retração por secagem com e sem restrição e de fluência básica a compressão

\subsection{Retração autógena}

Para os ensaios de retração autógena foram feitas misturas com cimento dos lotes I (53\% de C3S) e lote II (65\% de C3S), e com teores de $0,3,1,2$ e $2,7 \mathrm{~kg} / \mathrm{m}^{3}$ 
de fibras de curauá. As misturas com adição de fibras foram feitas com cimento do lote II.

Os resultados da deformação devido a retração autógena após 30min da mistura do cimento e da água são apresentados neste item. No gráfico da Figura 4.2 são apresentados os valores da deformação dos dois lotes de cimento utilizados na pesquisa, nomeados aqui de lote I e II. O comportamento das duas pastas foi semelhante, não havendo, assim, variação da retração autógena. Dentre os componentes minerais presentes no cimento, o que teve variação significativa entre lotes foi o $\mathrm{C}_{3} \mathrm{~S}$. Os demais componentes apresentaram nenhuma ou muito pouca variação. Dessa forma, pode-se afirmar que a variação no teor de $\mathrm{C}_{3} \mathrm{~S}$ dentro dos limites mínimos (53\%) e máximos (65\%) estabelecidos pela ASTM 114 [92] não afetam a retração autógena. Este resultado está de acordo com o encontrado por Tazawa e Miyazawa [21] e Jensen [25].

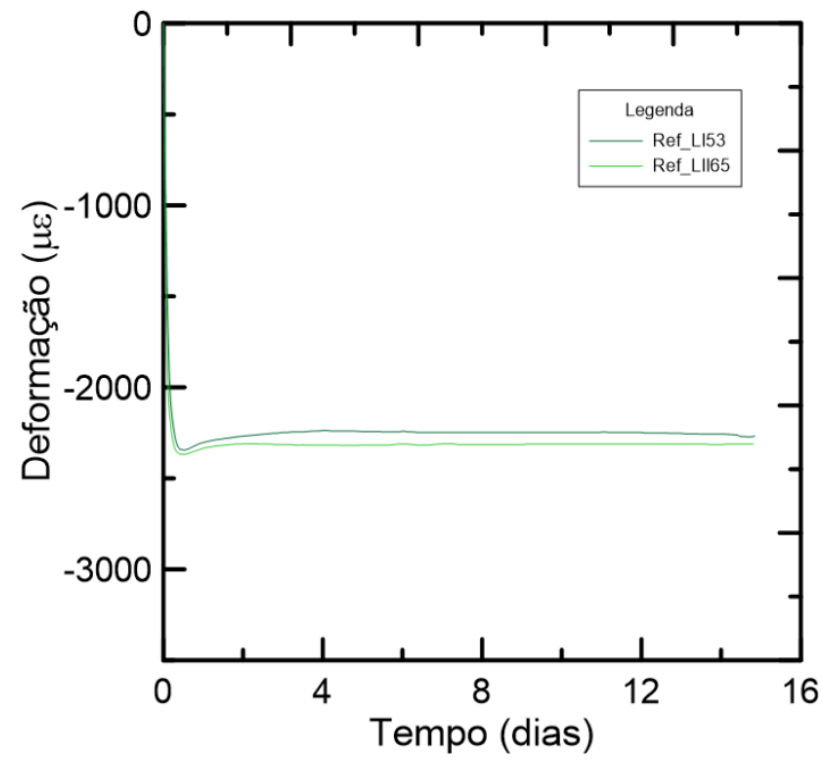

Figura 4.2 - Gráfico de retração autógena de pastas de cimento dos lotes I e II

O gráfico da figura 4.3 indica as deformações das misturas contendo fibras de curauá em comparação com a mistura de referência. Pode-se observar que a adição de $2,7 \mathrm{~kg} / \mathrm{m}^{3}$ de fibras de curauá diminuiu a retração autógena de forma significativa (45\%). Para o caso da mistura com $1,2 \mathrm{~kg} / \mathrm{m}^{3}$ de curauá, a adição da fibra não influenciou a retração. Por sua vez, a adição de $0,3 \mathrm{~kg} / \mathrm{m}^{3}$ influenciou pouco a retração (reduziu em 16\% se comparado a pasta de referência). A melhora da retração autógena na pasta com $2,7 \mathrm{~kg} / \mathrm{m}^{3}$ de fibras de curauá pode ser explicado pela capacidade de absorção de água da fibra. Além das fibras naturais aumentarem 
o teor de água na mistura, elas servem como reservatórios de água. Isso contribui para uma redução nas forças capilares da pasta fresca (já que os poros ficam preenchidos com água), diminuindo os valores de deformação por retração autógena [19, 42].

Uma melhora nos valores de deformação autógena com adição de fibra de celulose também foi observada por Kawashima e Shah [42] para teores de fibras de $2 \%$ da massa do cimento. Uma possível explicação para a diminuição da retração com a adição de fibras de curauá pode ser atribuída ao fato de que a fibra de curauá possui uma capacidade de absorção de água muito maior (3,5 vezes seu peso inicial [93]) do que as fibras de celulose utilizadas por Kawashima e Shah [42] (1,2 vezes seu peso inicial). Além disso, as fibras utilizadas nesta pesquisa tiveram tamanhos significativamente maiores. Dessa forma, uma quantidade menor de curauá é necessária para obter a mesma quantidade de água acrescentada a mistura pelas fibras de celulose saturadas.

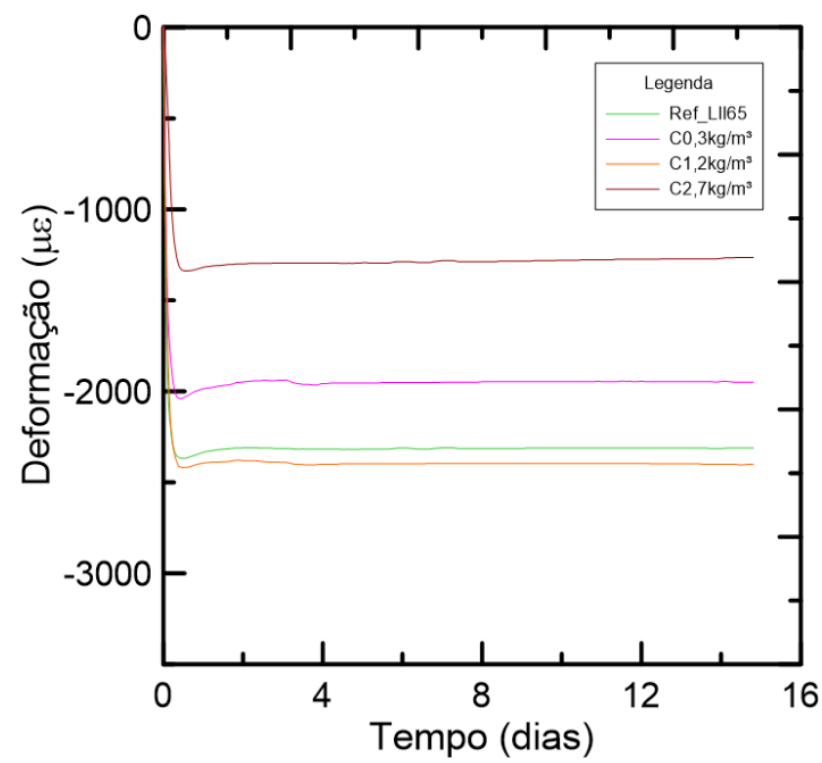

Figura 4.3 - Gráfico de retração autógena da pasta de referência e de pastas reforçadas com curauá

A Tabela 4.1 apresenta os valores finais de retração autógena. A tabela também apresenta os valores em \% do desempenho das pastas com reforço fibroso quando comparadas às pastas de referência. Os ensaios de retração autógena foram realizados com cimento classe $\mathrm{G}$ do lote II para as misturas com fibras. Foram moldados também pastas de referências com os lotes I e II. 
Tabela 4.1 - Valores dos ensaios de retração autógena

\begin{tabular}{cccccc}
\hline Deformação & Ref_LI53 & Ref_LII65 & C0,3 & C1,2 & C2,7 \\
\hline$\mu \varepsilon^{a}$ & -2268 & -2312 & -1949 & -2401 & -1264 \\
$\%^{b}$ & -2 & - & -16 & 4 & -45 \\
\hline
\end{tabular}

a Valores relativos ao décimo quarto dia de idade

${ }^{b}$ Redução/aumento da retração aos 14 dias em relação à referência, em \%

\subsection{Retração por secagem}

Para os ensaios de retração por secagem foram fabricados corpos de prova com teores de 0,3,1,2 e 2,7 kg/m³ de fibras de polipropileno e de curauá. As misturas utilizadas no ensaio de retração por secagem livre foram fabricadas utilizando cimento do lote I e as utilizadas nos ensaios de retração por secagem com restrição utilizando cimento lote II.

\subsubsection{Influência das fibras na retração livre}

O gráfico da Figura 4.4 mostra a retração livre das amostras com os diferentes teores de fibras de polipropileno. Pode-se afirmar que a adição de fibras de polipropileno na pasta de cimento reduziu a retração por secagem livre ligeiramente (em média, 8,13\%). A diferença na redução desta retração não aparentou ser impactada pelo teor de fibras de polipropileno (PP), uma vez que a redução foi de $8,6 \pm 2,0 \%, 9,0 \pm 2,3 \%$ e $6,8 \pm 0,6 \%$ para teores de $0,3,1,2$ e $2,7 \mathrm{~kg} / \mathrm{m}^{3}$, respectivamente. Dessa forma, dentre os três teores de fibras investigados neste trabalho, a adição de $0,3 \mathrm{~kg} / \mathrm{m}^{3}$ de fibra de PP seria suficiente para a redução da retração na proporção apresentada. Essa redução na retração livre pode ser devido à restrição da fibra à ação de deslizamento da matriz durante a retração, que se dá por meio da força de ligação interfacial entre fibra-matriz [94]. Uma redução no valor da retração livre com a adição de fibras de PP também foi observada por outros autores [36, 38-40] e pode ser atribuída ao seu comprimento curto e ao seu baixo módulo de elasticidade [36]. 


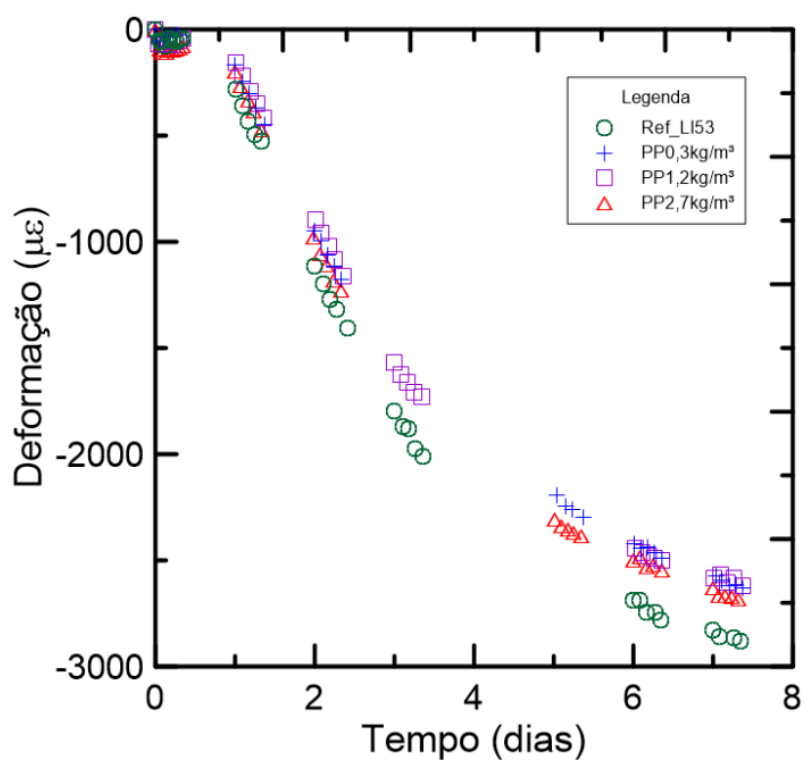

Figura 4.4 - Gráfico de retração livre da pasta de referência e de pastas reforçadas com PP

Para as fibras de curauá, apenas a mistura com teor de $2,7 \mathrm{~kg} / \mathrm{m}^{3}$ de curauá apresentou uma redução de 8,5\% na retração por secagem livre. Os demais teores aparentaram não influenciar a retração. A redução foi de apenas 1,4\% e 2,7\%, para os teores de 0,3 e $1,2 \mathrm{~kg} / \mathrm{m}^{3}$, respectivamente. O gráfico da Figura 4.5 apresenta o comportamento dessas misturas com reforço de curauá.

Os resultados obtidos na presente pesquisa para retração livre em pastas reforçadas com fibra natural divergem dos encontrados por Toledo Filho et al. [45] e por Sales [44]. Ambos os autores encontraram um aumento no valor da deformação por retração livre com a adição de fibras naturais. Toledo Filho et al. [45] sugere que a deformação aumenta porque a adição de fibras naturais aumenta a porosidade do compósito, criando caminhos de saída de água. É importante observar que:

(a) as fibras naturais têm alta variabilidade - os autores usaram fibras de 25 mm de sisal e de coco;

(b) os teores utilizados pelos autores foram maiores (2 a 3\% da massa do aglomerante), e, portanto, mesmo se observando uma tendência na redução da retração com o aumento do teor de curauá, não se pode afirmar que este comportamento seria representativo para altos teores. $\mathrm{O}$ teor mais alto utilizado nesta pesquisa foi equivalente a $0,3 \%$ da massa do cimento, e o menor teor utilizado por Toledo Filho et al. [45] foi $2 \%$ da massa dos aglomerantes; 
(c) o tempo de duração do ensaio do autor foi de 320 dias e a presente pesquisa avaliou a retração em idades jovens, de até 14 dias de idade. Dessa forma, não se pode prever que em idades avançadas o comportamento das pastas reforçadas com curauá permaneçam na mesma proporção;

(d) o método de ensaio, os componentes da mistura e as dimensões dos corpos de prova também foram diferentes. Os autores não detalharam se usaram fibras secas ou saturadas.

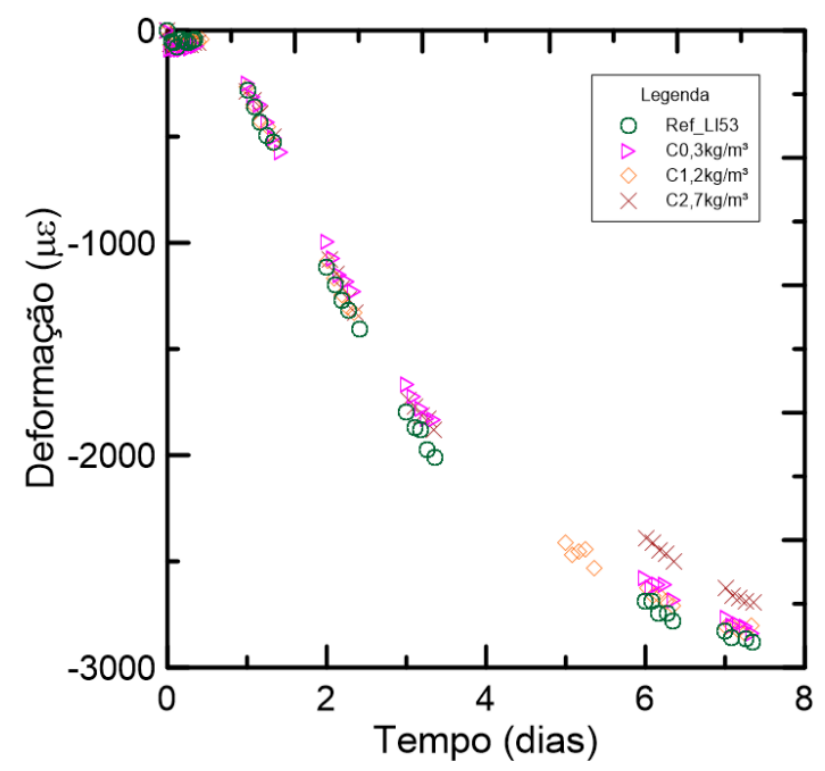

Figura 4.5 - Gráfico de retração livre da pasta de referência e de pastas reforçadas com curauá

De uma maneira geral, é possível observar que a adição de fibras não influenciou a retração livre nas primeiras horas. E a diferença nos valores aumentou com o aumento da duração dos ensaios - a maior diferença entre os valores da deformação livre foi no sétimo dia de idade das misturas.

Os gráficos da Figura 4.6 estão organizados por teor de fibras na mistura. É possível observar que as amostras com 0,3 e $1,2 \mathrm{~kg} / \mathrm{m}^{3}$ de fibra de polipropileno apresentaram maiores reduções na retração livre do que as com fibras de curauá com os mesmos teores. O mesmo não ocorre para misturas com teores de fibra de $2,7 \mathrm{~kg} / \mathrm{m}^{3}$, que apresenta uma redução semelhante para ambas as fibras. A sutil diferença nos valores de retração livre pode ser explicada pelo fato das misturas com fibras de curauá apresentarem mais água disponível para evaporar durante a secagem, por terem sido adicionadas saturadas na mistura. Dessa forma, as amostras contendo fibras naturais teriam uma maior quantidade de água evaporável, apresentando valores de retração maiores do que as fibras secas de PP. 

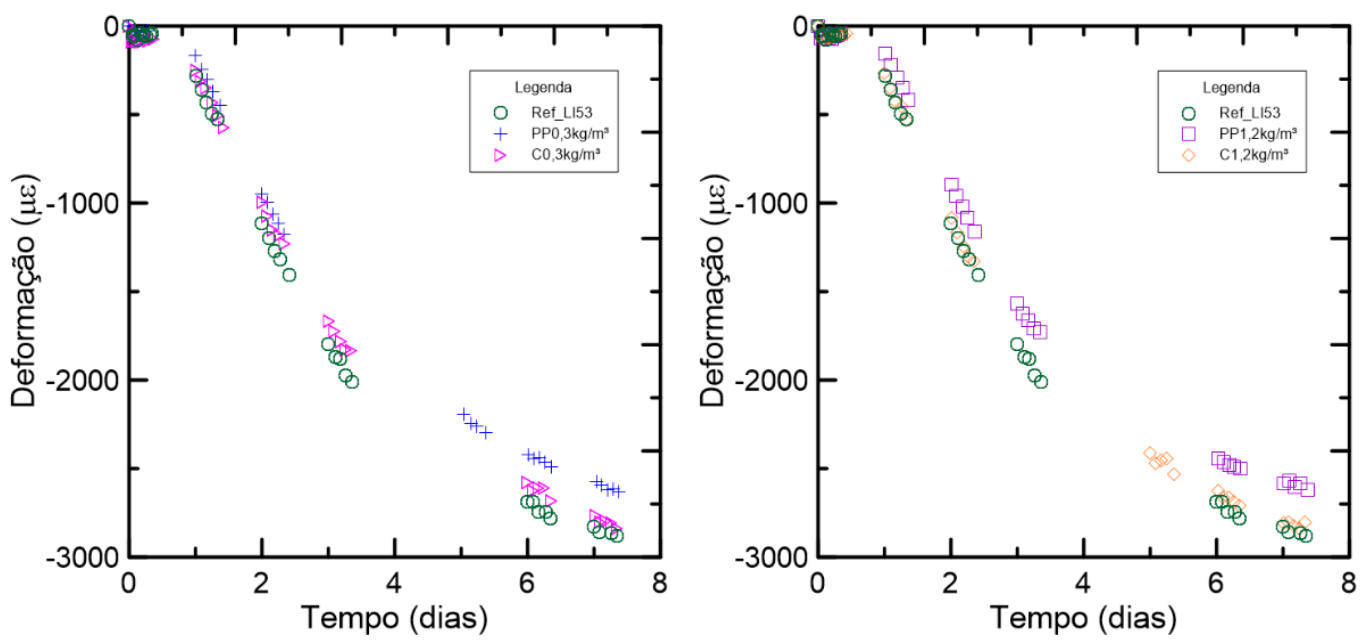

(a)

(b)

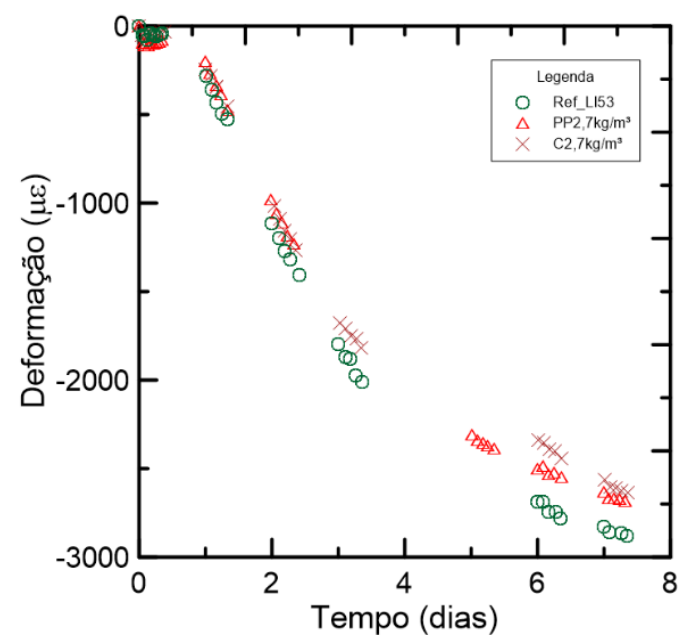

(c)

Figura 4.6 - Gráficos de retração por secagem livre separados por teores de fibras nas misturas:

(a) $0,3 \mathrm{~kg} / \mathrm{m}^{3}$; (b) $1,2 \mathrm{~kg} / \mathrm{m}^{3}$; (c) $2,7 \mathrm{~kg} / \mathrm{m}^{3}$

A Tabela 4.2 apresenta os valores médios de retração por secagem livre ao fim dos ensaios. A tabela também apresenta os valores em $\%$ do desempenho das pastas com reforço fibroso quando comparadas às pastas de referência. Os ensaios de retração por secagem livre foram realizados com cimento classe $\mathrm{G}$ do lote I para as misturas com e sem fibras. 
Tabela 4.2 - Valores médios dos ensaios de retração livre

\begin{tabular}{|c|c|c|c|c|c|c|c|c|}
\hline Deformação & Ref_LI53 & Ref_LII65 & $P P 0,3$ & PP1,2 & PP2,7 & $c 0,3$ & $C 1,2$ & $C 2,7$ \\
\hline$\mu \varepsilon^{a}$ & -2880 & - & -2633 & -2620 & -2684 & -2839 & -2803 & -2635 \\
\hline$\%^{b}$ & - & - & 8,6 & 9,0 & 6,8 & 1,4 & 2,7 & 8,5 \\
\hline D.P. ${ }^{c}$ & 49 & - & 56 & 67 & 17 & 50 & 10 & 26 \\
\hline
\end{tabular}

\subsubsection{Influência das fibras na perda de massa}

Os gráficos da Figura 4.7 apresentam a perda de massa, em \%, ao longo do tempo das amostras de PP e curauá durante o ensaio da retração por secagem livre. Todas as amostras tiveram a mesma área de superfície exposta durante a secagem. É possível observar que a taxa de perda de massa é alta nas primeiras 24 horas para todas as misturas. Entre 1 e 3 dias de ensaio, há uma redução nessa taxa. Após este período, a perda de massa aparenta se estabilizar até o sétimo dia de ensaio. Podese observar uma redução na perda de massa dos compósitos com ambas as fibras. Durante as primeiras horas de ensaio, a perda de massa foi semelhante para todas as amostras, mas ao longo do ensaio, a diferença entre amostras com e sem fibras aumentou. No final do período de ensaio, nota-se que a diferença entre as perdas de massa das amostras se mantém constante. 


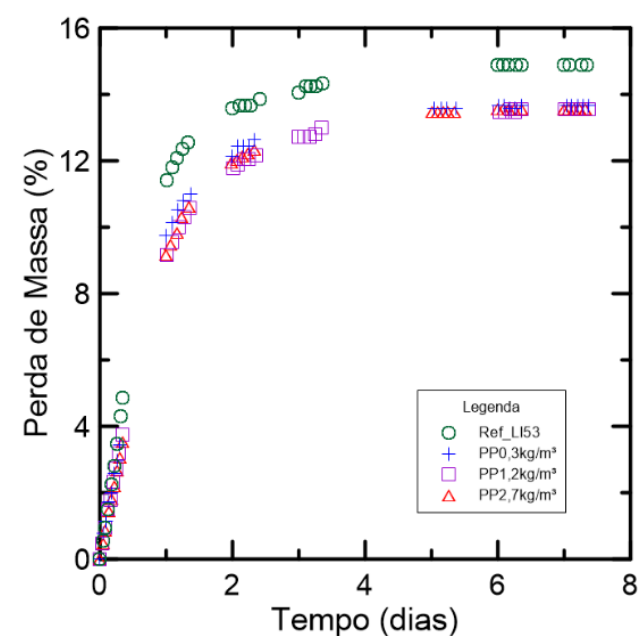

(a)

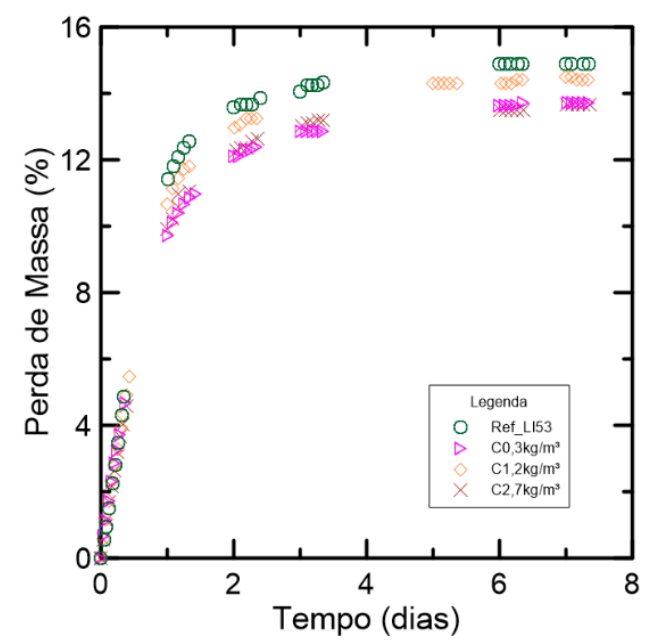

(b)

Figura 4.7 - Perda de massa dos corpos de prova de referência e reforçados com fibras de (a) polipropileno e (b) curauá

O resultado encontrado nesta pesquisa diverge do encontrado por outros autores. Toledo Filho [74] observou que a perda de massa da matriz aumenta ligeiramente quando as fibras de sisal e coco são adicionadas à mistura: quanto mais fibras se adiciona, maior a perda de massa medida.

Os gráficos da Figura 4.8 apresentam a relação deformação versus perda de massa das amostras analisadas. O comportamento de ambas as pastas com e sem fibras apresentam a mesma tendência. Quando a perda de massa devido à evaporação de água das amostras está entre 0 e 9\%, a deformação por retração livre é muito pequena. No entanto, ela aumenta consideravelmente quando a perda de massa varia entre 12 e $15 \%$. Para uma mesma deformação, a perda de massa das amostras sem fibras foi maior que para amostras com fibras. 


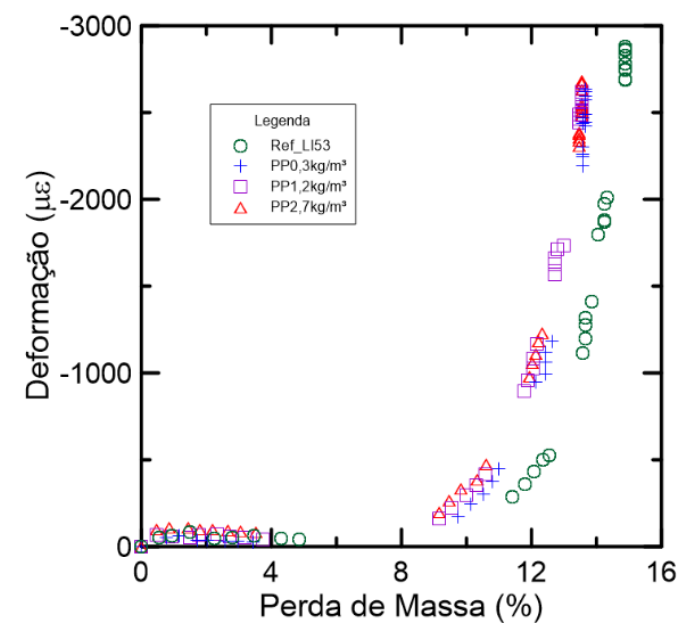

(a)

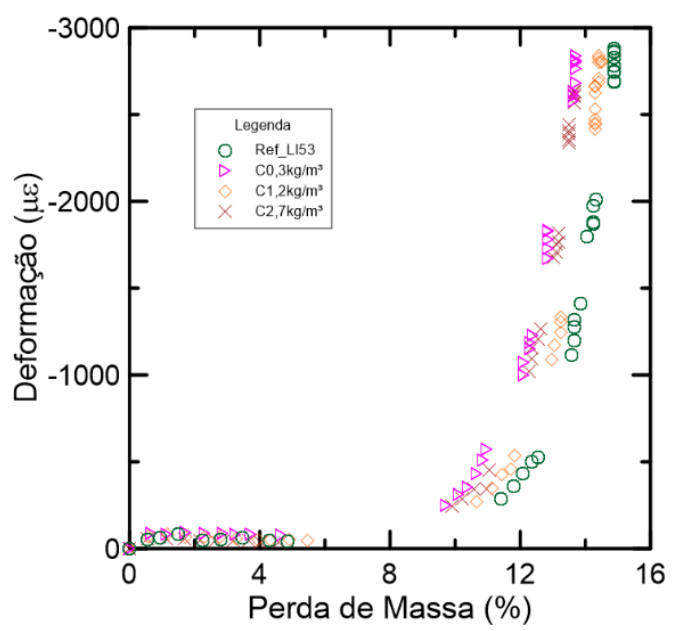

(b)

Figura 4.8 - Gráfico de retração livre por perda de massa da referência e de fibras de (a) polipropileno e (b) curauá

\subsubsection{Influência das fibras na retração com restrição}

\subsubsection{Influência das fibras na idade de fissuração}

Os cálculos para avaliação da fissuração dos anéis de pasta de cimento e os gráficos obtidos por eles e pela leitura da deformação encontram-se nesta seção. $\mathrm{O}$ esquema da Figura 4.9, adaptado de Shah e Weiss [95], ilustra o desenvolvimento das tensões nos anéis de aço interno e do corpo de prova desde a leitura da deformação dos extensômetros ilustrado na Figura 4.9 (a). Segundo os autores, a retração por secagem sofrida pelo corpo de prova exerce uma pressão na interface do anel interno de aço, $P_{\text {int }}$ (b) e é calculada pela equação (1). Uma tensão residual no corpo de prova aparece devido à restrição gerada pelo anel de aço (c) e pode ser calculada pela equação (2). Combinando as equações (1) e (2), pode-se obter a máxima tensão de tração desenvolvida no anel (d), dada pela equação (3). Essa equação (3) só é válida no regime linear, até o momento em que a fissura se desenvolve. No entanto, utiliza-se esta equação para calcular a tensão pósfissuração uma vez que a falta de ligação entre o corpo de prova e o anel de aço permite que as tensões e deformações sejam redistribuídas no anel [95].

$$
P_{\text {int }}(t)=-\varepsilon_{a c ̧ o}(t) \times E_{a c ̧ o} \times\left(\frac{R_{e a}^{2}-R_{i a}^{2}}{2 \times R_{e a}^{2}}\right)
$$




$$
\begin{aligned}
& \sigma_{\text {residual }}=P_{\text {int }} \times\left(\frac{R_{i c}^{2}}{R_{e c}^{2}-R_{i c}^{2}}\right) \times\left(1+\frac{R_{e c}^{2}}{r^{2}}\right) \\
& \sigma_{\text {max }}=-\varepsilon_{a c ̧ o}(t) \times E_{a c ̧ o} \times\left(\frac{R_{i c}^{2}+R_{e c}^{2}}{R_{e c}^{2}-R_{i c}^{2}}\right) \times\left(\frac{R_{i c}^{2}-R_{i a}^{2}}{2 \times R_{i c}^{2}}\right)
\end{aligned}
$$

Onde,

$P_{\text {int }}=$ pressão interfacial,

$\sigma_{\text {residual }}=$ tensão residual desenvolvida no anel,

$\sigma_{\max }=$ tensão máxima desenvolvida no anel,

$\varepsilon_{\text {aço }}=$ deformação medida no anel de aço,

$E_{a c ̧ o}=$ módulo de elasticidade do anel de aço,

$R_{e a}=$ raio externo do anel de aço,

$R_{i a}=$ raio interno do anel de aço,

$R_{e c}=$ raio externo do anel de concreto,

$R_{i c}=$ raio interno do anel de concreto, $\mathrm{e}$

$r=$ espessura do anel de pasta.

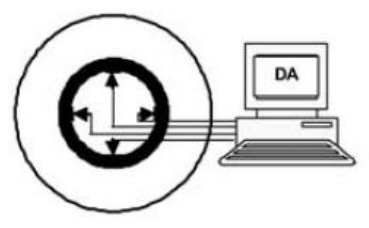

(a)
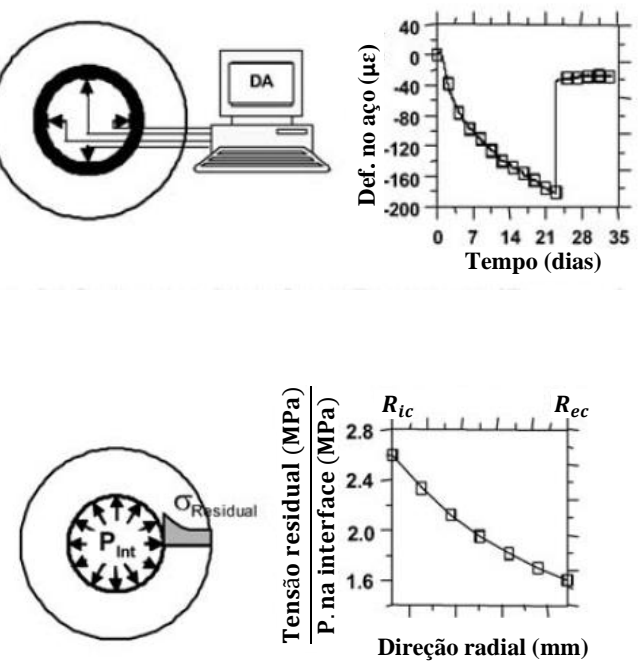

(c) (b)
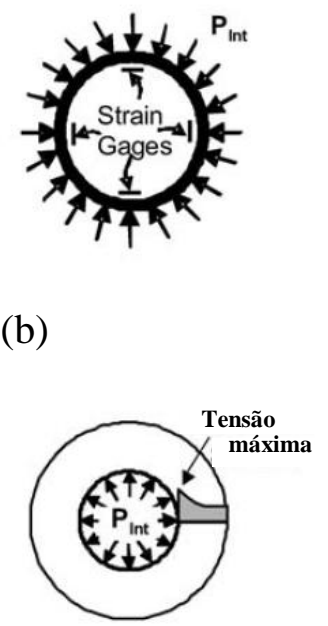

(d)
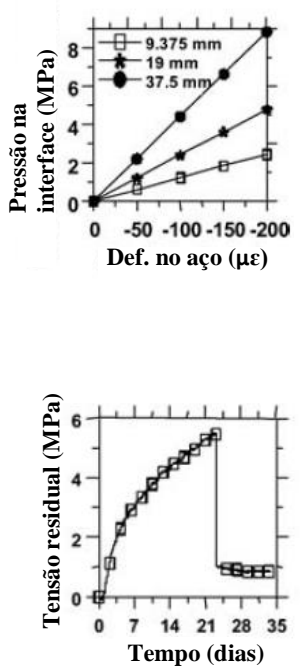

Tempo (dias)

Figura 4.9 - Esquema representando as etapas para o cálculo da tensão no corpo de prova de anel, adaptado de Shah e Weiss [95]: (a) leitura da deformação pelos extensômetros; (b) pressão na interface anel de aço-pasta; (c) desenvolvimento da tensão residual na direção radial; (d) tensão máxima obtida no corpo de prova 
A Figura 4.10 ilustra os gráficos de tensão e deformação típicas para este tipo de ensaio. A linha tracejada nos gráficos representa momento em que o anel foi desmoldado. Ambos os gráficos apresentam valores nulos no instante da moldagem. A deformação máxima do anel de aço e a correspondente tensão máxima ocorre no momento da fissuração. A fissura é representada por uma queda repentina na tensão e na deformação do anel e pode ser vista claramente no gráfico.

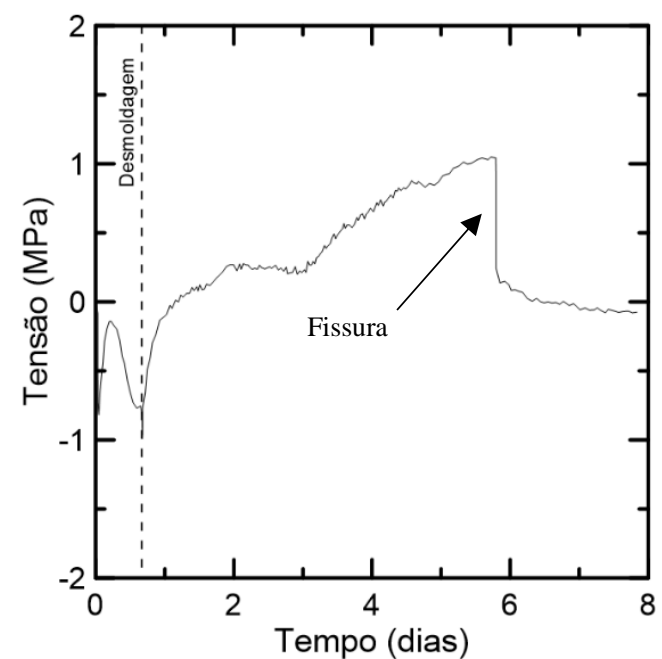

(a)

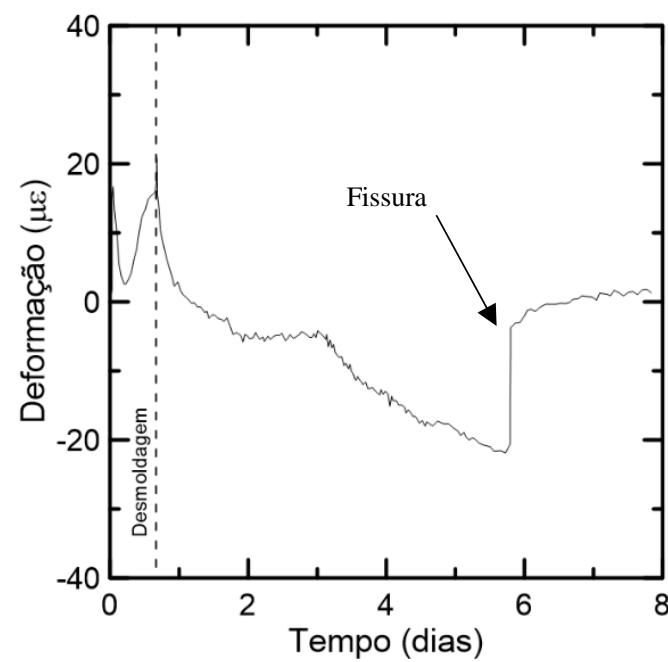

(b)

Figura 4.10 - Gráficos típicos de (a) tensão e (b) deformação do ensaio de retração por secagem com restrição pelo método do anel

Os dados do desenvolvimento de deformação no anel de aço interno para cada mistura ensaiada em função do tempo a partir da moldagem são apresentados nas Figuras 4.11 a 4.16. Foram plotados também gráficos do desenvolvimento da tensão associada a deformação no anel obtidos pela equação (3), e também estão apresentados nas Figuras 4.11 a 4.16. Os valores apresentados representam a média entre os extensômetros utilizados para aquisição da deformação no anel de aço interno. No apêndice B encontram-se os gráficos do desenvolvimento das deformações de cada extensômetro para cada mistura.

A adição de fibras de PP e curauá adiou a idade de fissuração do anel de pasta de cimento. Os gráficos das Figuras 4.11 e 4.12 apresentam o desenvolvimento da tensão nas pastas e da deformação no anel de aço interno pelo tempo de duração dos ensaios das misturas com fibra de polipropileno e curauá, respectivamente. Pelo gráfico da Figura 4.11, a adição de $0,3,1,2$ e $2,7 \mathrm{~kg} / \mathrm{m}^{3}$ de fibras de polipropileno adiou a idade de fissuração em 24, 17 e 23\% em relação a pasta de referência. Pelo gráfico da Figura 4.12 a idade de fissuração foi adiada em 14, 18 e 18\% para pastas 
com adição de $0,3,1,2$ e $2,7 \mathrm{~kg} / \mathrm{m}^{3}$ de fibras de curauá, respectivamente. A Figura 4.13 apresenta a idade de aparecimento das fissuras em cada mistura ensaiada, em horas.

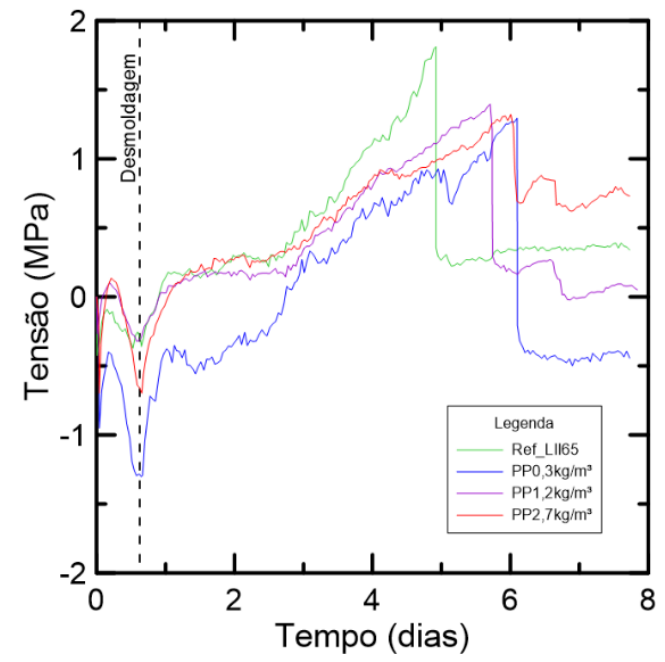

(a)

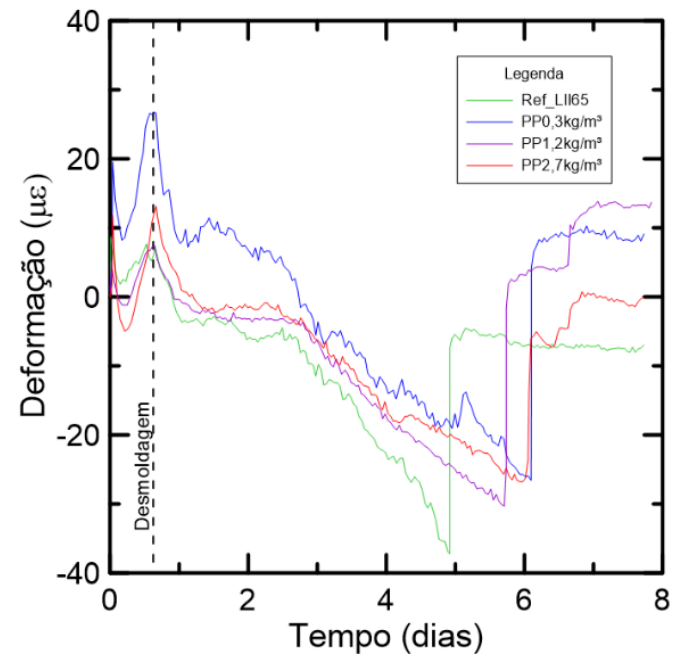

(b)

Figura 4.11 - Gráfico de retração com restrição da pasta de referência e de pastas reforçadas com polipropileno. (a) Desenvolvimento da tensão no anel de pasta; (b) Desenvolvimento da deformação no anel de aço interno

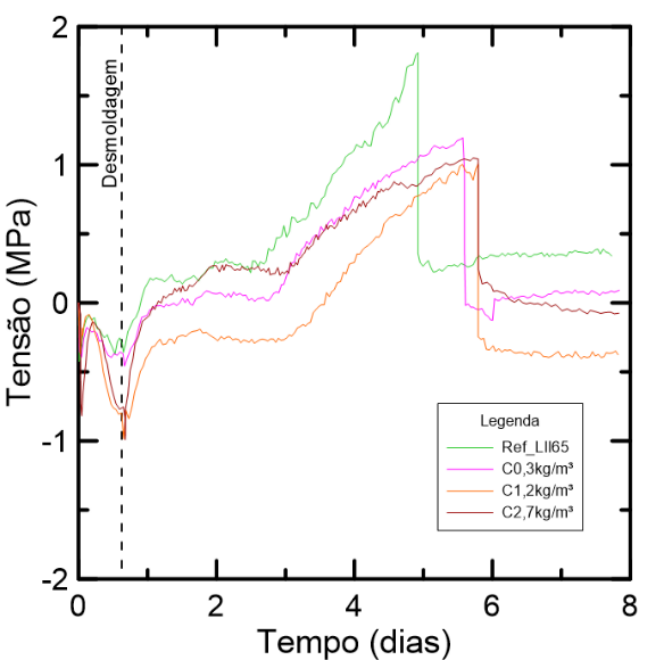

(a)

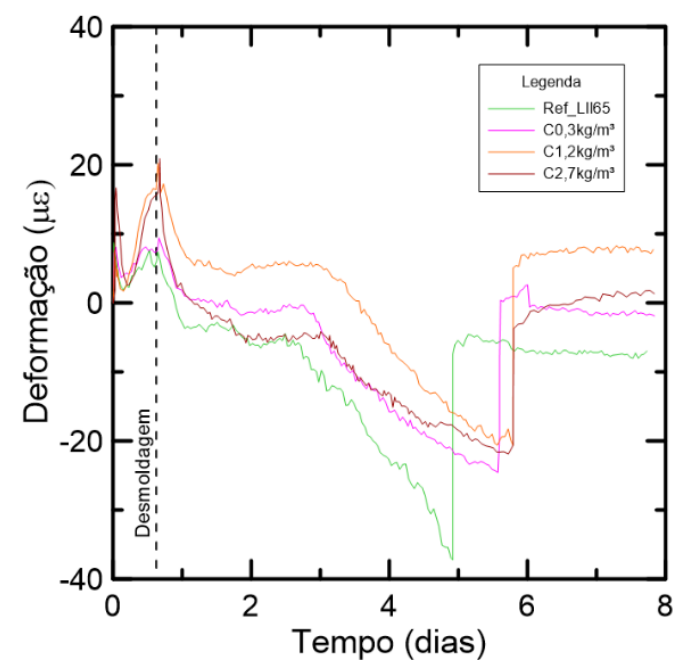

(b)

Figura 4.12 - Gráfico de retração com restrição da pasta de referência e de pastas reforçadas com curauá. (a) Desenvolvimento da tensão no anel de pasta; (b) Desenvolvimento da deformação no anel de aço interno 


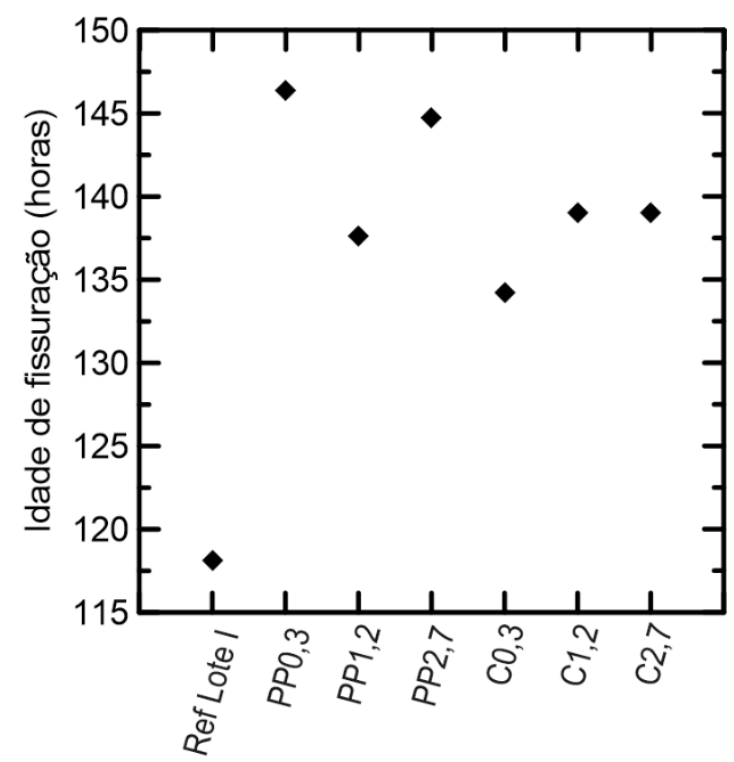

Figura 4.13 - Idade do corpo de prova no momento da fissura para cada mistura

Os gráficos das Figuras 4.14, 4.15 e 4.15 apresentam o desenvolvimento da tensão no anel de aço interno das misturas com $0,3,1,2$ e $2,7 \mathrm{~kg} / \mathrm{m}^{3}$ de fibras. As fibras de PP apresentaram uma melhora para os teores de 0,3 e $2,7 \mathrm{~kg} / \mathrm{m}^{3}$ quando comparadas as fibras de curauá com mesmos teores. Para a adição de $1,2 \mathrm{~kg} / \mathrm{m}^{3}$, as fibras de curauá e de polipropileno apresentaram desempenho semelhante.

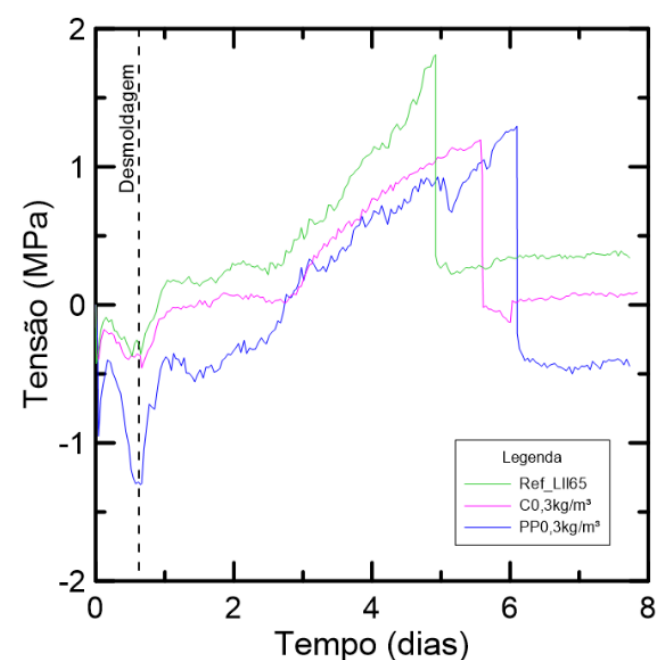

(a)

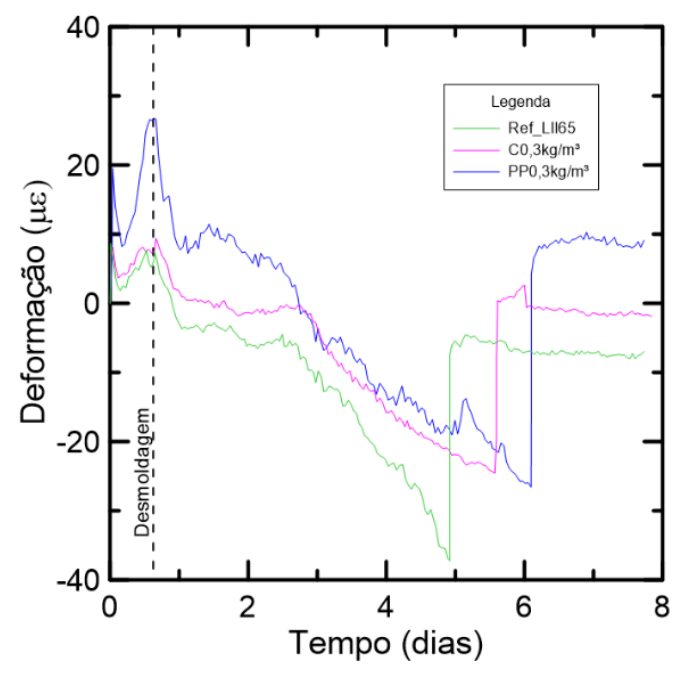

(b)

Figura 4.14 - Gráficos de (a) tensão e (b) deformação do ensaios de retração por secagem com restrição em pastas com adição de $0,3 \mathrm{~kg} / \mathrm{m}^{3}$ de fibras 


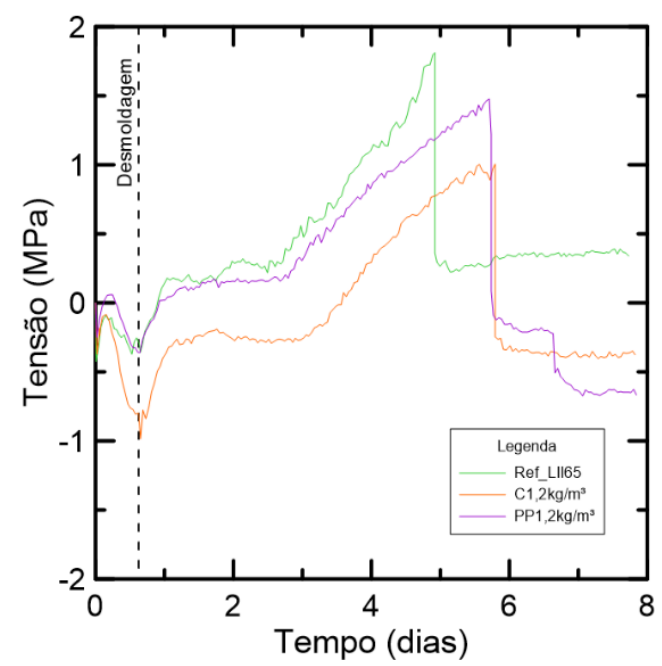

(a)

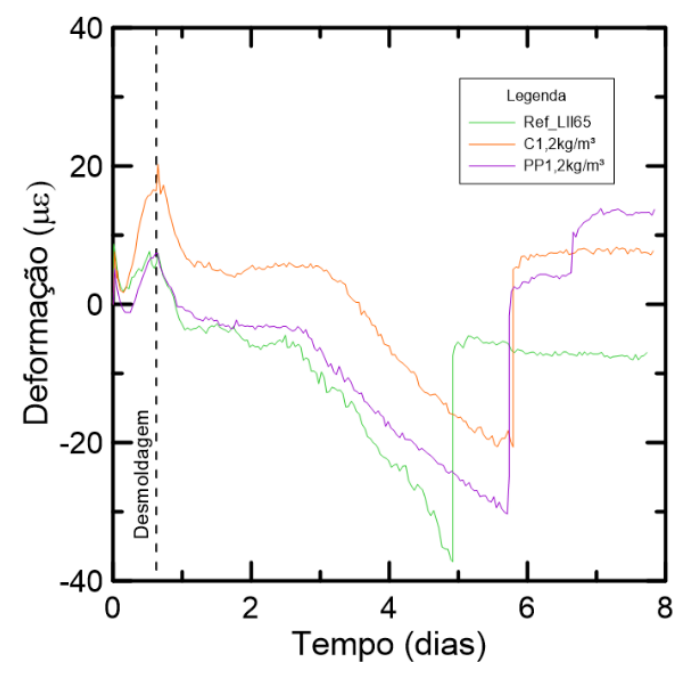

(b)

Figura 4.15 - Gráficos de (a) tensão e (b) deformação do ensaios de retração por secagem com restrição em pastas com adição de $1,2 \mathrm{~kg} / \mathrm{m}^{3}$ de fibras

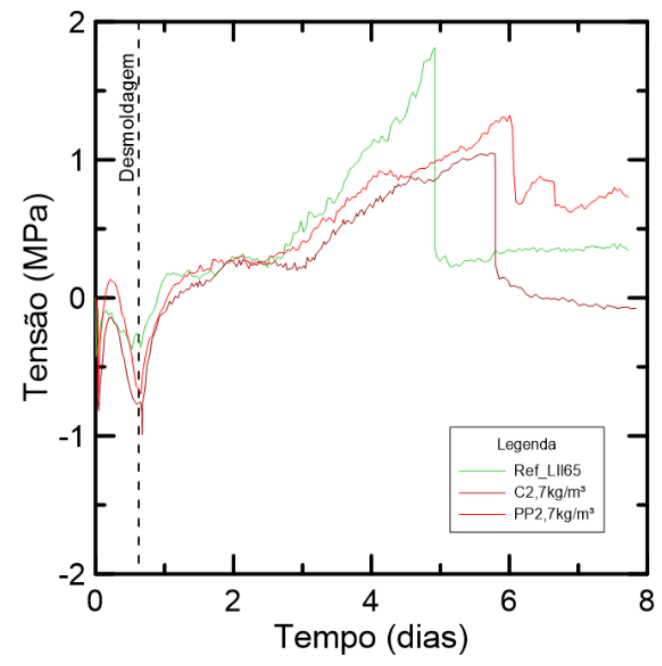

(a)

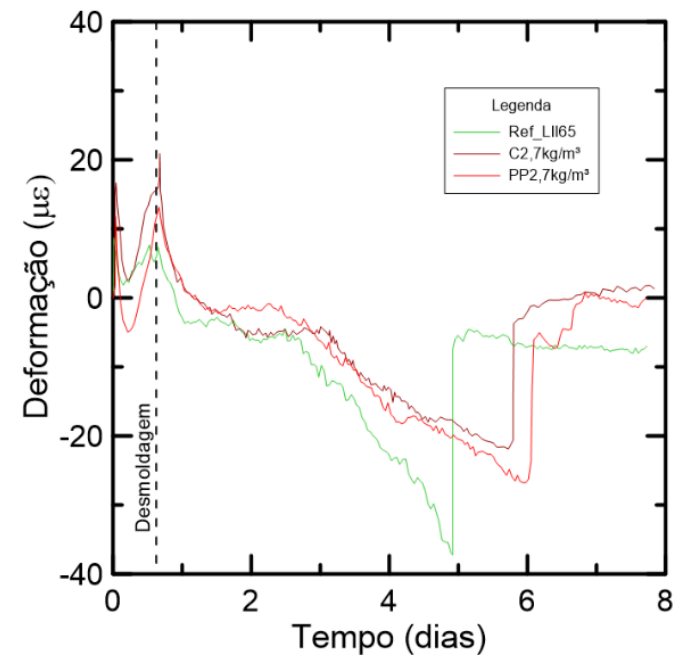

(b)

Figura 4.16 - Gráficos de (a) tensão e (b) deformação do ensaios de retração por secagem com restrição em pastas com adição de $2,7 \mathrm{~kg} / \mathrm{m}^{3}$ de fibras

No intuito de se obter indicativos da resistência à fissuração das misturas, foi calculada a taxa de tensão de tração máxima (no instante antes do aparecimento da fissura) de acordo com o indicado na ASTM C1581 [89]:

$$
S=\frac{G\left|\alpha_{m}\right|}{2 \times \sqrt{t_{r}}}
$$


Onde,

$S=$ taxa de tensão em cada corpo de prova, $\mathrm{MPa} / \mathrm{dia}$,

$G=48,7 \mathrm{GPa}$ para esta pesquisa $\left(\sigma_{\max } / \varepsilon_{a c ̧ o}\right)$,

$\left|\alpha_{m}\right|=$ valor absoluto da média do fator da taxa de deformação de cada ensaio, $(\mathrm{m} / \mathrm{m}) / \mathrm{dia}^{1 / 2}$, e

$t_{r}=$ tempo decorrido a partir do momento que o corpo de prova foi exposto a secagem até o momento da fissura, dia.

O valor de $\alpha$ é obtido através da inclinação do gráfico de deformação ("net strain") versus raiz quadrada do tempo a partir do início da secagem. Dessa forma:

$$
\varepsilon_{n e t}=\alpha \times \sqrt{t}+k
$$

Onde,

$\varepsilon_{n e t}=$ deformação ("net strain"), calculada a partir do início da secagem do corpo de prova, $\mathrm{m} / \mathrm{m}$,

$\alpha=$ fator da taxa de deformação de cada extensômetro, $(\mathrm{m} / \mathrm{m}) / \mathrm{dia}^{1 / 2}$,

$t=$ tempo decorrido a partir do momento que o corpo de prova foi exposto a secagem, dia, e

$k=$ constante ("regression constante").

Foi plotado um gráfico de deformação "net strain" média versus raiz quadrada do tempo para cada mistura, como ilustrado na Figura 4.17. Os gráficos de cada uma dessas misturas se encontram no apêndice B. Os valores de $\alpha$ encontram-se na Tabela 4.3, assim como os valores correspondentes da taxa de tensão de tração máxima e do tempo a partir da desmoldagem. 


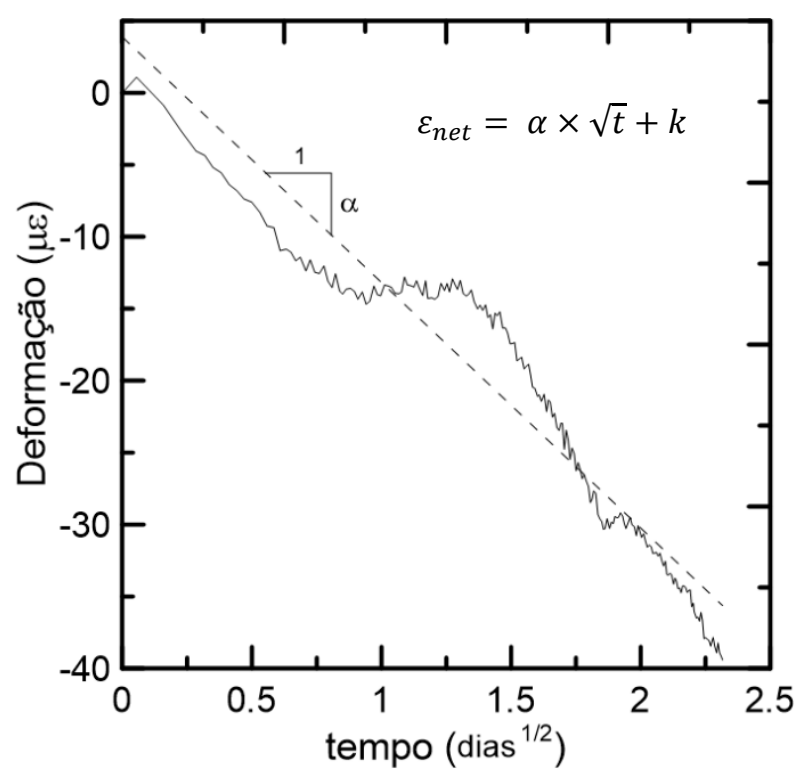

Figura 4.17 - Gráfico de deformação a partir da desmoldagem em função da raiz quadrada do tempo no mesmo período para mistura com adição de $2,7 \mathrm{~kg} / \mathrm{m}^{3}$ de polipropileno

Tabela 4.3 - Valores obtidos pelo ensaio de retração com restrição das misturas

\begin{tabular}{|c|c|c|c|c|}
\hline & $\begin{array}{c}t_{r} \\
\text { (dias) }\end{array}$ & $\begin{array}{c}\alpha \\
\left((m / m) / \operatorname{dia}^{1 / 2}\right)\end{array}$ & $\begin{array}{c}S \\
(M P a / d i a)\end{array}$ & D.P. ${ }^{1}$ \\
\hline Ref_LII65 & 4,30 & 19,21 & 0,226 & 0,045 \\
\hline$c 0,3$ & 4,93 & 16,69 & 0,183 & 0,026 \\
\hline$C 1,2$ & 4,47 & 20,05 & 0,231 & 0,023 \\
\hline C 2,7 & 5,13 & 14,40 & 0,155 & 0,020 \\
\hline$P P 0,3$ & 5,43 & 21,82 & 0,228 & 0,036 \\
\hline$P P 1,2$ & 5,07 & 17,57 & 0,190 & 0,033 \\
\hline PP 2,7 & 5,36 & 17,06 & 0,179 & 0,013 \\
\hline
\end{tabular}

É possível perceber que a taxa de tensão das misturas com e sem fibras foram muito próximas. Além disso, todas as pastas fissuraram antes dos primeiros sete dias. See et al. [96] classificaram o potencial a fissuração de um material de acordo com o apresentado na Tabela 4.4. Pela classificação, todas as pastas estudadas nesta pesquisa apresentam alto potencial de fissuração. No entanto, é importante notar que esta classificação é estabelecida para argamassas e concretos, e não para pastas. 
Tabela 4.4 - Potencial de fissuração, adaptado de See et al. [96]

\begin{tabular}{cc}
\hline $\boldsymbol{t}_{r}$ (dias) & Potencial para fissuração \\
\hline $0<t_{r} \leq 7$ & Alto \\
$7<t_{r} \leq 14$ & Moderado-Alto \\
$14<t_{r} \leq 28$ & Moderado-Baixo \\
$t_{r}>28$ & Baixo \\
\hline
\end{tabular}

Para pastas com adição de polipropileno, pode-se perceber uma ligeira tendência a redução da taxa com o aumento no teor das fibras. Para o caso da adição de curauá, a menor taxa de tensão também foi encontrada nas pastas com maior teor dessas fibras. Dessa forma, sugere-se que as fibras ajudam na redução da taxa de tensão, e que o aumento do teor delas na mistura é benéfico neste sentido.

\subsubsection{Influência das fibras na abertura de fissuras}

A adição de fibras de PP e curauá reduziu a abertura das fissuras. Os gráficos da Figura 4.18 apresenta o desenvolvimento da abertura de fissuras das pastas durante o período de ensaio e em função do teor e tipo de fibras utilizadas como reforço. É possível observar, por estes gráficos, que a abertura de fissuras reduziu com o aumento no teor dessas fibras tanto de 0,3 para $1,2 \mathrm{~kg} / \mathrm{m}^{3}$ quanto de 1,2 para $2,7 \mathrm{~kg} / \mathrm{m}^{3}$. As fibras de PP tiveram uma redução mais significativa na abertura de fissura com o aumento no teor dessas fibras quando comparado as fibras de curauá. A redução chegou a $91 \%$ para o teor de $2,7 \mathrm{~kg} / \mathrm{m}^{3}$ de fibras de polipropileno e $80 \%$ para o mesmo teor de fibras de curauá, quando comparadas à pasta sem reforço fibroso. 


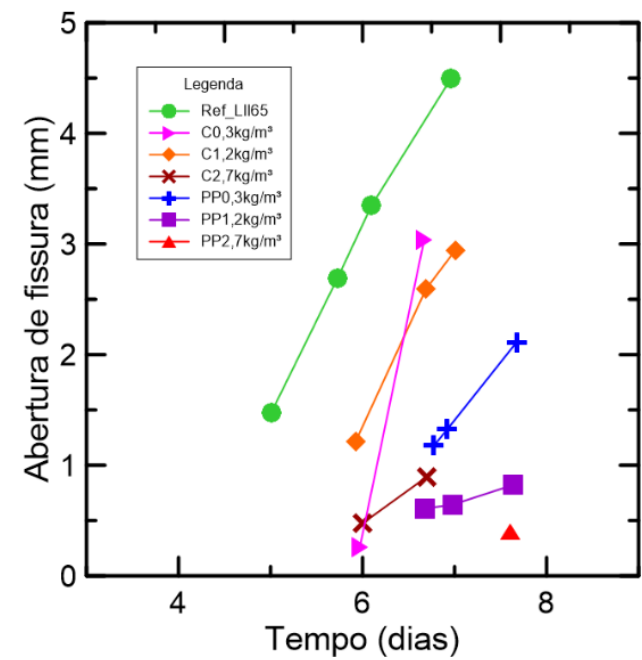

(a)

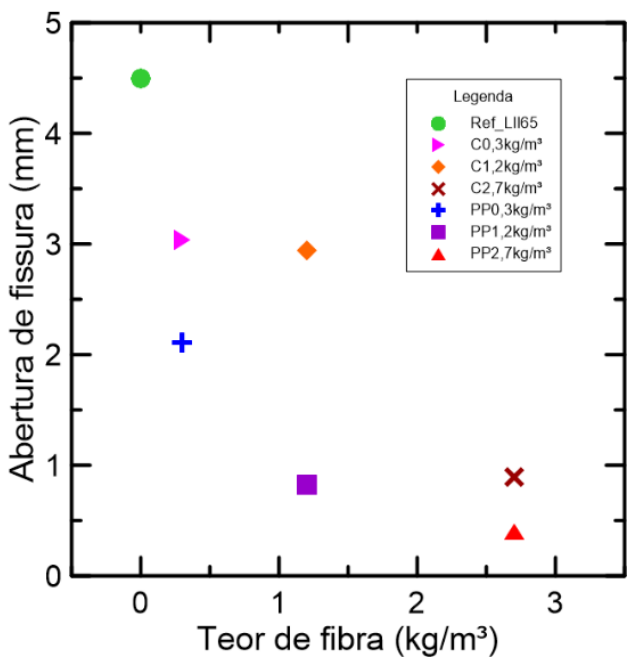

(b)

Figura 4.18 - Gráficos da abertura de fissura em função do tempo (a) e do teor de fibras (b)

A Figura 4.19 apresenta (a) as fissuras da pasta de referência e (b) da pasta com adição de $1,2 \mathrm{~kg} / \mathrm{m}^{3}$. A Figura 4.19 (c) apresenta em detalhe a distribuição das fibras de curauá na zona do anel fissurado. É possível perceber que o método de mistura foi eficiente na dispersão das fibras. Esta mesma qualidade de dispersão foi observada na zona de fissuras das outras pastas reforçadas tanto com curauá como com polipropileno. 


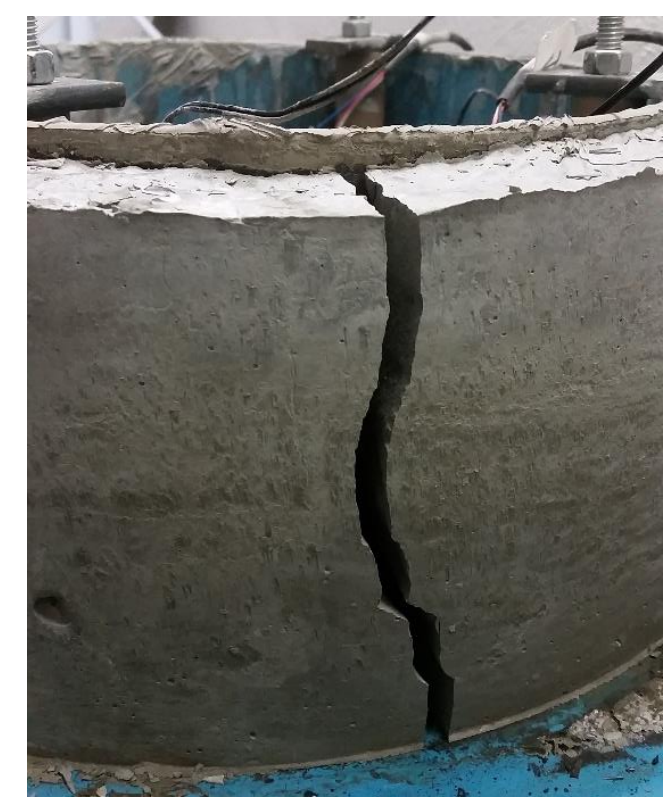

(a)

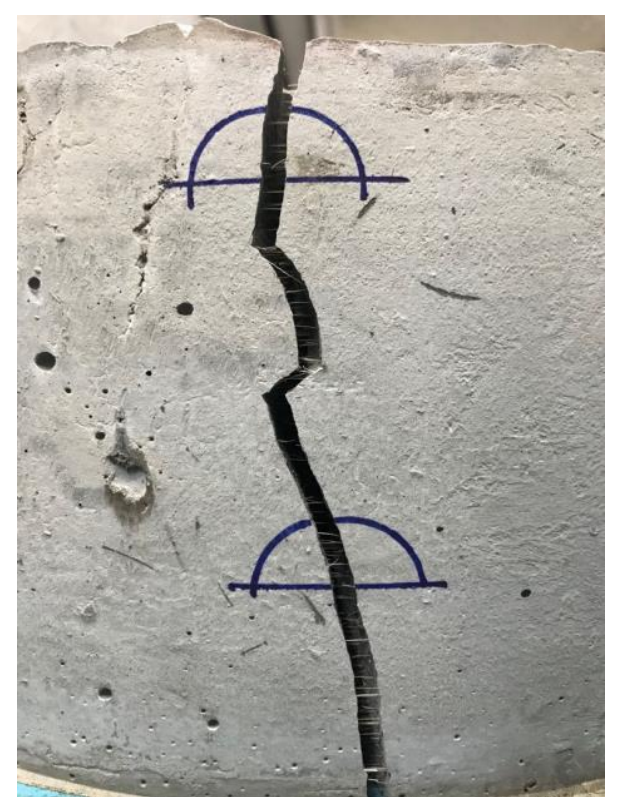

(b)

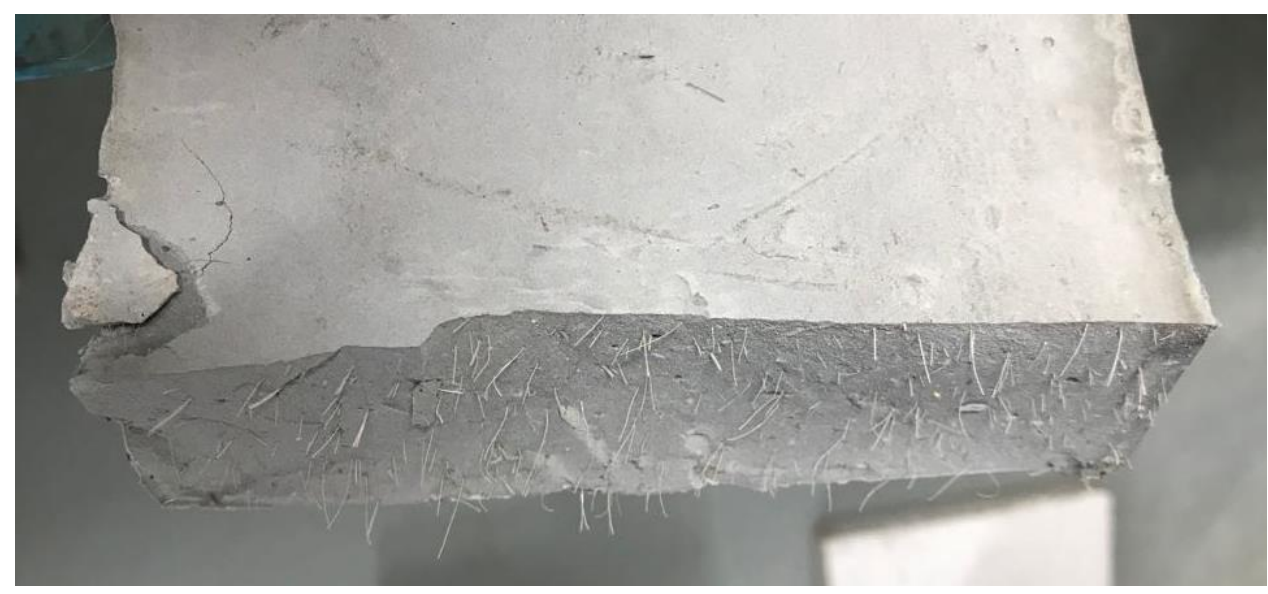

(c)

Figura 4.19 - Acompanhamento da abertura de fissuras: (a) fissura no anel de referência, (b) fissura no anel com $1,2 \mathrm{~kg} / \mathrm{m}^{3}$ de curauá e (c) detalhe da dispersão das fibras de curauá na fissura

A redução na abertura das fissuras é esperado, uma vez que as fibras servem de ponte de transferência de tensão da matriz, redistribuindo os esforços internos [97]. Outros autores também chegaram a conclusões semelhantes do adiamento idade de fissuração e da redução abertura delas em materiais cimentícios reforçados com fibras [36-38]. Segundo Daneti e Wee [37], as fibras são relativamente inativas até o momento do surgimento das fissuras, porque não modificam significativamente o desenvolvimento da tensão pré-fissuração.

Uma razão para a influência benéfica das fibras de PP é dada por Zhang e Li [40]. Segundo os autores, essas fibras podem compensar uma parte do esforço de tração causada pela retração por secagem da pasta de cimento. Isso se deve à sua 
alta resistência a tração e alta capacidade de se deformar. As fibras também reduzem indiretamente a tensão de retração porque diminui a concentração dela.

Sales [44] observou uma melhora na fissuração com a adição de polpa de bambu em pasta de cimento. Rapoport e Shah [43] e Kawashima e Shah [42] também observaram uma redução significativa na abertura de fissuras com a adição teores variados (a partir de $0,14 \%$ ) de fibras de celulose.

A Tabela 4.5 apresenta um resumo dos resultados dos ensaios de retração por secagem com restrição. A tabela também apresenta os valores em \% do desempenho das pastas com reforço fibroso quando comparadas às pastas de referência. Os ensaios de retração por secagem com restrição foram realizados com cimento classe $\mathrm{G}$ do lote II para as misturas com e sem fibras.

Tabela 4.5 - Valores médios dos ensaios de retração por secagem com restrição

\begin{tabular}{cccccccccc} 
Idade de & & Ref_LI53 & Ref_LII65 & PP0,3 & PP1,2 & PP2,7 & $\mathbf{C 0 , 3}$ & $\mathbf{C 1 , 2}$ & $\mathbf{C 2 , 7}$ \\
\cline { 2 - 10 } $\begin{array}{c}\text { aparecimento } \\
\text { da fissura }\end{array}$ & $\boldsymbol{h}^{a}$ & - & 118 & 146 & 138 & 145 & 134 & 139 & 139 \\
& $\%^{b}$ & - & - & 23,7 & 16,9 & 22,9 & 13,6 & 17,8 & 17,8 \\
\hline & & & & & & & & & \\
\hline $\begin{array}{c}\text { Abertura da } \\
\text { fissura }\end{array}$ & $\mathbf{m m}^{a}$ & - & 4,50 & 2,11 & 0,82 & 0,40 & 3,04 & 2,94 & 0,90 \\
\hline$\%^{b}$ & - & - & $-53,0$ & $-81,8$ & $-91,2$ & $-32,4$ & $-34,5$ & $-80,0$ \\
\hline
\end{tabular}

${ }^{a}$ Valores relativos ao sétimo dia de idade

${ }^{b}$ Redução/aumento da retração em relação à referência, em \%

\subsection{Fluência}

Para os ensaios de fluência básica foram fabricados corpos de prova com cimento dos lotes I (53\% de C3S) e lote II (65\% de C3S), e com teores de 0,3, 1,2 e $2,7 \mathrm{~kg} / \mathrm{m}^{3}$ de fibras de polipropileno e de curauá. As misturas com adição de fibras foram feitas com cimento do lote I.

O gráfico da Figura 4.20 apresenta a deformação por fluência das pastas de referência dos lotes de cimento I e II. O principal componente mineral com variação significativa entre lotes é o $\mathrm{C}_{3} \mathrm{~S}$. Pode-se observar que o cimento lote II (com maior teor de $\mathrm{C}_{3} \mathrm{~S}$ ) teve uma deformação total $40 \%$ maior quando comparado ao cimento lote I. No entanto, quando se compara a deformação por fluência sem a deformação elástica inicial, é possível observar que o comportamento de ambas as misturas é similar. As misturas com cimento lote II apresentaram uma redução de $12 \%$ na deformação por fluência básica. Considerando a variabilidade apresentada pelas 
misturas (encontradas no apêndice $\mathrm{B}$ ), pode-se afirmar que a variação de $\mathrm{C}_{3} \mathrm{~S}$ dentro dos limites estabelecidos pela ASTM 114 [92] não influencia significativamente a deformação por fluência.

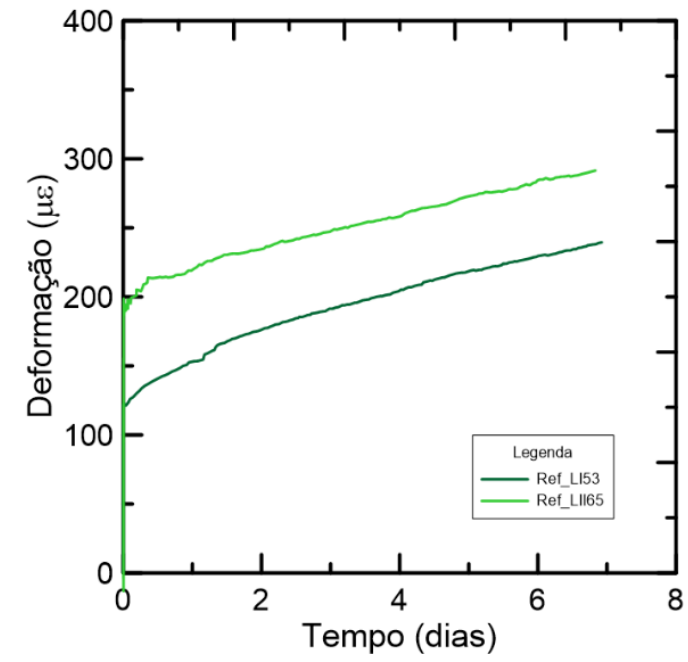

(a)

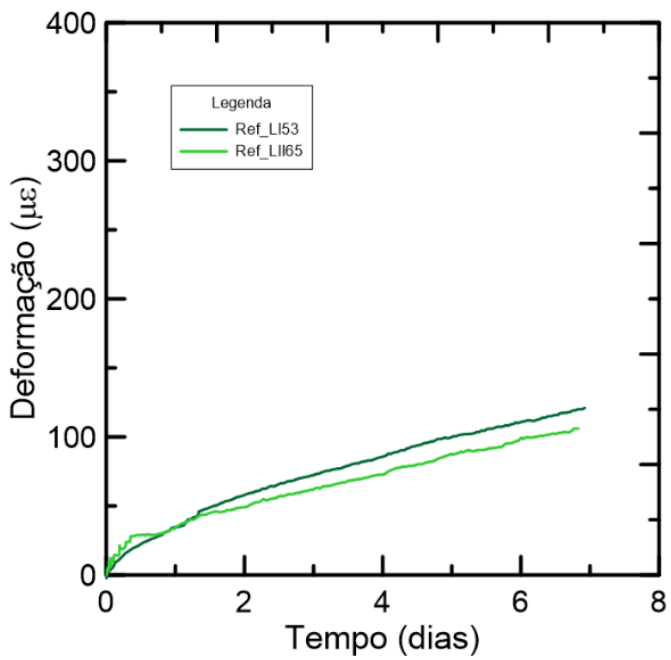

(b)

Figura 4.20 - Deformação por fluência de pastas com cimento dos lotes I e II (a) com deformação elástica; (b) sem deformação elástica

A composição química e a estrutura do C-S-H têm influência na fluência de materiais cimentícios [98]. Considera-se que o gel de C-S-H é formado por dois tipos de C-S-H, de composição semelhantes, mas empacotamento diferentes: C-SH de baixa (LD C-S-H) e de alta densidade (HD C-S-H) [99]. A Figura 4.21 apresenta um esquema 2-D dos dois tipos de C-S-H. Alguns autores explicam o fenômeno da fluência pelo movimento da água entra as camadas de C-S-H. O C-S$\mathrm{H}$ de baixa densidade possui maior porosidade do gel $[98,99]$ e, portanto, seria responsável por maiores deformações por fluência [101]. $\mathrm{O} \mathrm{C}_{3} \mathrm{~S}$ é o principal responsável pela formação do gel de C-S-H nas primeiras idades [102] e, como o produto inicial da hidratação é o C-S-H de baixa densidade [103], esperava-se que o maior teor de $\mathrm{C}_{3} \mathrm{~S}$ resultasse em maior fluência. Apesar de os resultados apresentados na presente pesquisa não terem indicado tal influência, é possível que para maiores variações no teor de $\mathrm{C}_{3} \mathrm{~S}$ tal efeito seja notado. 


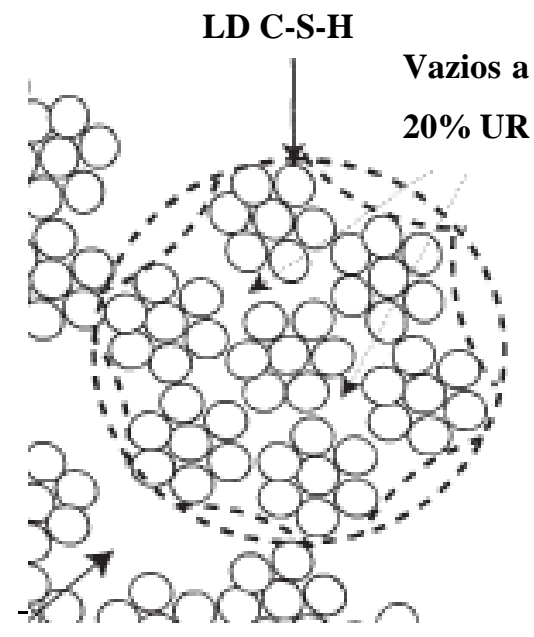

(a)

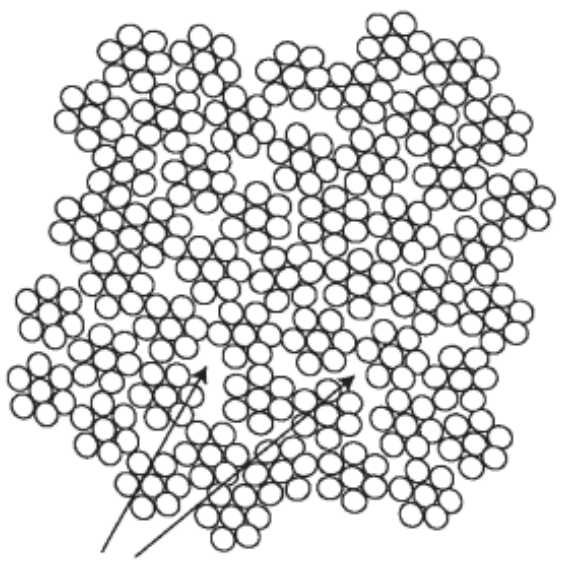

Poros inacessíveis

Figura 4.21 - Esquema 2-D do C-S-H de (a) baixa densidade e (b) alta densidade, adaptado de [99]

As deformações das amostras com polipropileno e pasta de referência estão apresentadas na Figura 4.22. As amostras com $2,7 \mathrm{~kg} / \mathrm{m}^{3}$ de polipropileno apresentaram redução significativa na deformação elástica inicial se comparado à pasta de referência e dosagens menores. Os menores teores de fibra de polipropileno apresentaram maior deformação elástica inicial se comparado à pasta de referência. O gráfico da Figura 4.22 (b) apresenta a deformação desconsiderando a elástica inicial. É possível observar que, de maneira geral, a adição de fibras pouco influenciou a deformação por fluência. A redução foi de 1, 7 e 17\% para os teores de $0,3,1,2$ e $2,7 \mathrm{~kg} / \mathrm{m}^{3}$ de PP, respectivamente. É possível observar uma tendência a redução da deformação por fluência com o aumento no teor das fibras de polipropileno. 


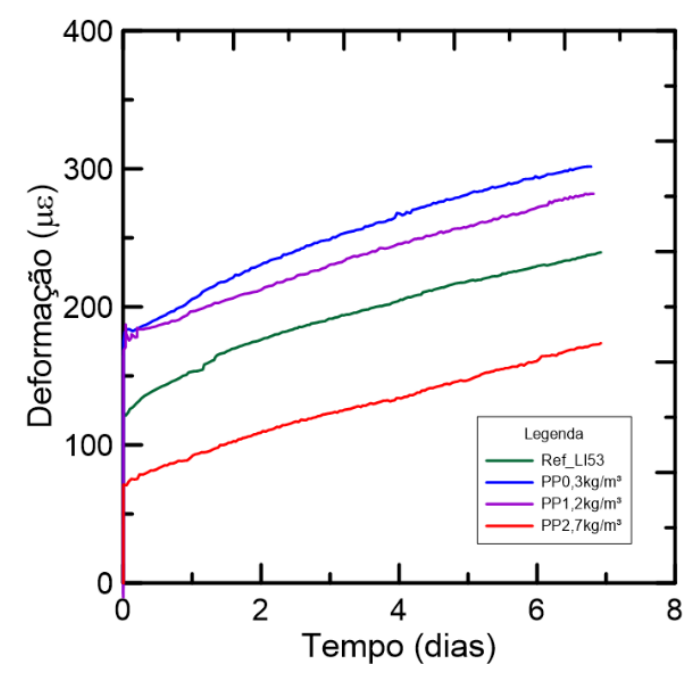

(a)

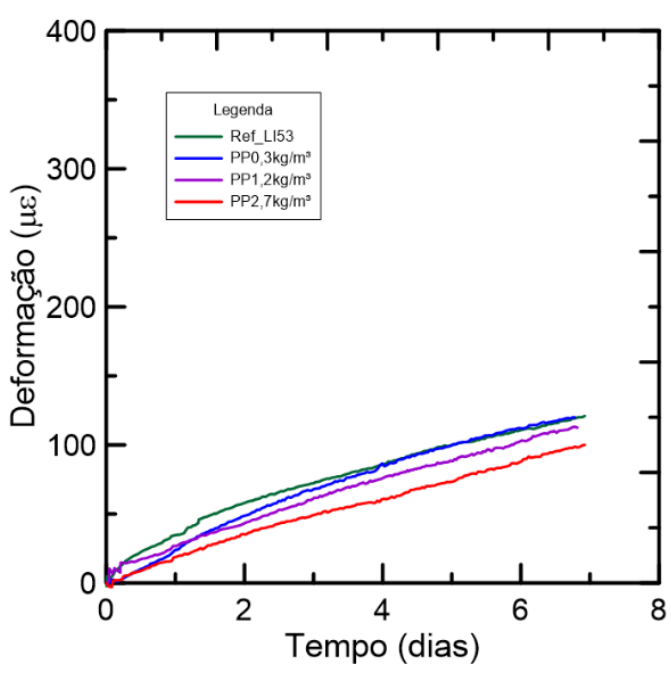

(b)

Figura 4.22 - Gráfico de fluência da pasta de referência e de pastas reforçadas com PP (a) com deformação elástica; (b) sem deformação elástica

A Figura 4.23 apresenta as deformações das amostras com fibras de curauá com (a) e sem (b) deformação elástica inicial. Os corpos de prova com teor de fibra de $0,3 \mathrm{~kg} / \mathrm{m}^{3}$ de fibra de curauá não influenciaram a deformação elástica inicial do compósito (redução de $1 \%$ ). A adição de $1,2 \mathrm{~kg} / \mathrm{m}^{3}$ e $2,7 \mathrm{~kg} / \mathrm{m}^{3}$ de fibras de curauá apresentaram valores maiores de deformação ao final do período de ensaio, e o teor de fibras influenciou de forma a aumentar essa deformação inicial dos compósitos com o aumento do teor de fibras de curauá presentes na mistura. Esse aumento foi de 33 e $45 \%$ para os teores de 1,2 e $2,7 \mathrm{~kg} / \mathrm{m}^{3}$ de curauá quando comparados a referência, respectivamente. Quando se observa apenas a deformação por fluência, excluindo a deformação elástica inicial, observa-se que a adição de 1,2 e $2,7 \mathrm{~kg} / \mathrm{m}^{3}$ de fibras de curauá reduziu em 12 e 5\% a deformação por fluência, e que a adição de $0,3 \mathrm{~kg} / \mathrm{m}^{3}$ aumentou em $2 \%$ essa deformação. No entanto, a variabilidade nos valores de deformação por fluência para os teores de 0,3 e $2,7 \mathrm{~kg} / \mathrm{m}^{3}$ foi alto e estão apresentados no apêndice C. 


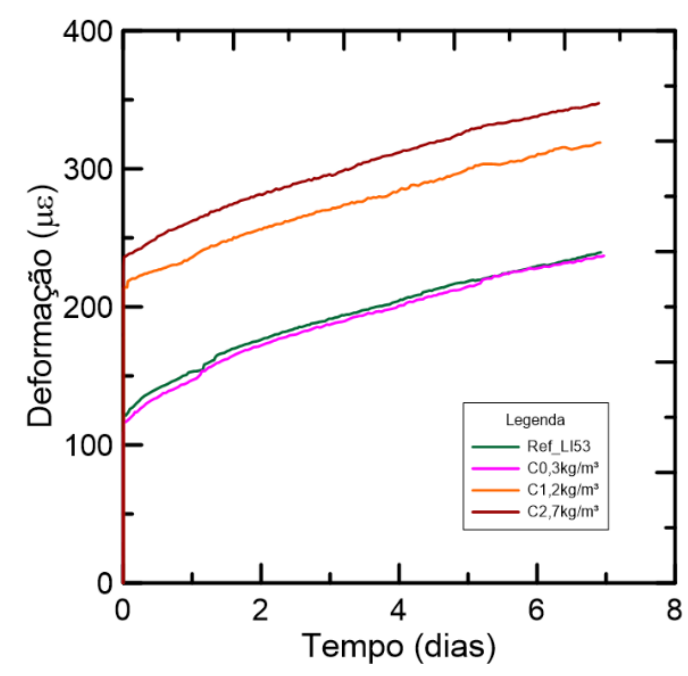

(a)

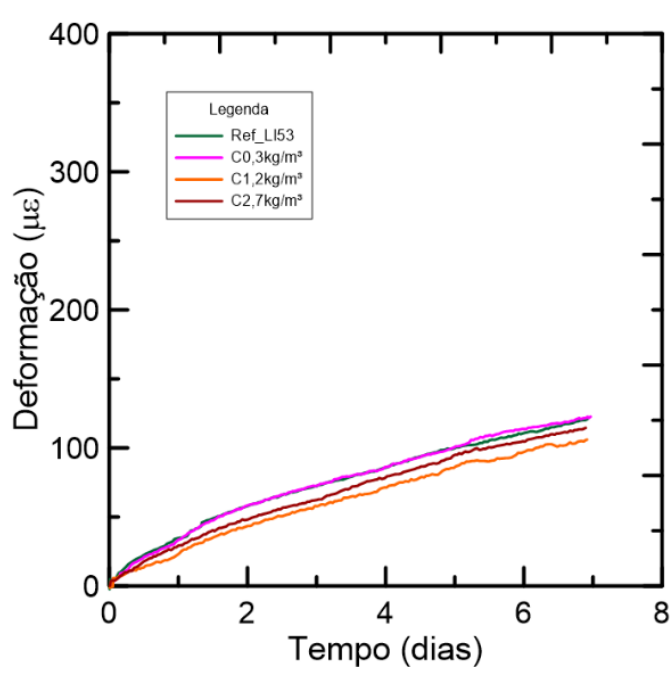

(b)

Figura 4.23 - Gráfico de fluência da pasta de referência e de pastas reforçadas com curauá (a) com deformação elástica; (b) sem deformação elástica

As Figuras de 4.24 a 4.26 apresentam as deformações por fluência separadas por teor de fibras estudadas nesta pesquisa: $0,3,1,2$ e $2,7 \mathrm{~kg} / \mathrm{m}^{3}$, respectivamente. Para dosagens de $0,3 \mathrm{~kg} / \mathrm{m}^{3}$, as fibras de PP apresentaram maior valor de deformação elástica inicial (26\% maior que a referência). Quando comparado apenas a deformação por fluência, não foi observado influência da adição de fibras no teor analisado (redução de $1 \%$ para adição de PP e aumento de $2 \%$ para adição de curauá, quando comparados a referência). A adição de $1,2 \mathrm{~kg} / \mathrm{m}^{3}$ de fibras aumentou a deformação elástica inicial, sendo que a mistura com curauá apresentou o maior valor de deformação (33\% maior que a referência). Quando analisada apenas a deformação por fluência, compósitos com teor de $1,2 \mathrm{~kg} / \mathrm{m}^{3}$ de fibras apresentaram reduções de 7 e $12 \%$ para polipropileno e curauá, respectivamente. A deformação elástica inicial dos corpos de prova com $2,7 \mathrm{~kg} / \mathrm{m}^{3}$ de curauá foi maior $45 \%$ do que para pasta de referência. Compósitos com mesmo teor de PP apresentaram redução de $28 \%$ na deformação total. A deformação por fluência reduziu em 5 e $17 \%$ para adição de curauá e polipropileno, respectivamente. 


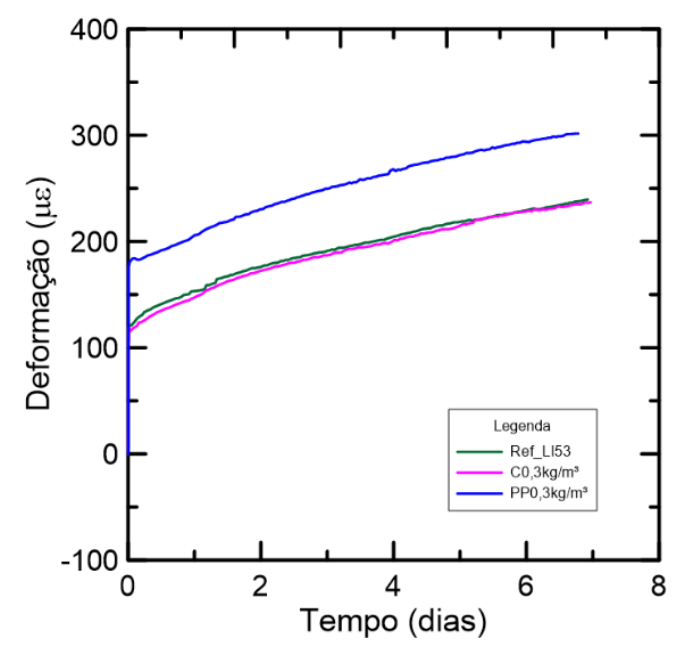

(a)

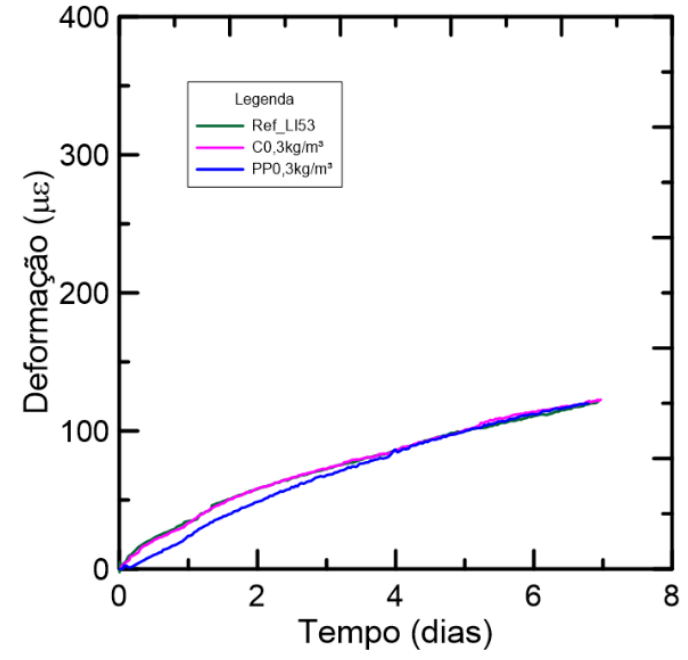

(b)

Figura 4.24 - Gráficos de fluência (a) com deformação elástica e (b) sem deformação elástica em pastas com adição de $0,3 \mathrm{~kg} / \mathrm{m}^{3}$ de fibras

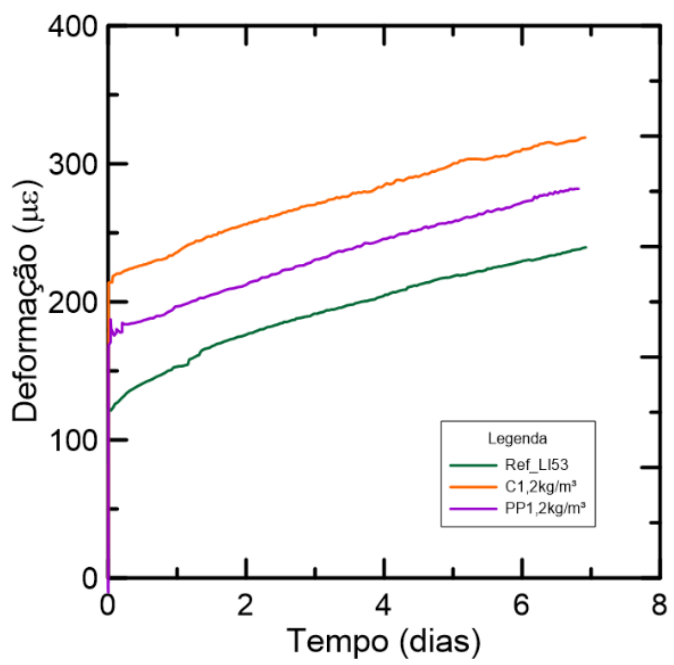

(a)

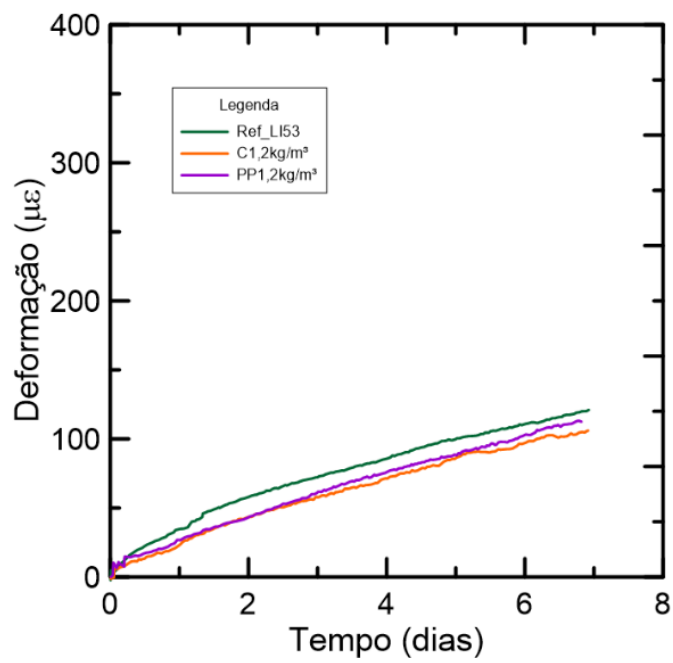

(b)

Figura 4.25 - Gráficos de fluência (a) com deformação elástica e (b) sem deformação elástica em pastas com adição de $1,2 \mathrm{~kg} / \mathrm{m}^{3}$ de fibras 


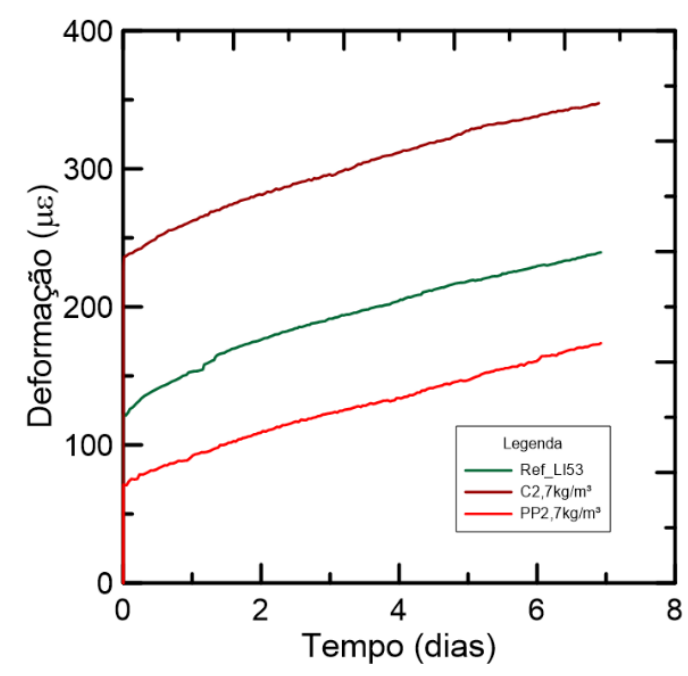

(a)

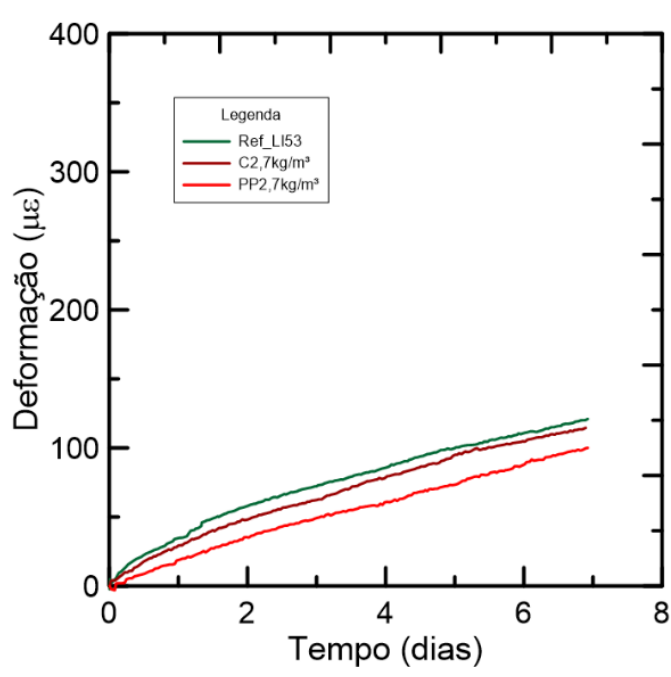

(b)

Figura 4.26 - Gráficos de fluência (a) com deformação elástica e (b) sem deformação elástica em pastas com adição de $2,7 \mathrm{~kg} / \mathrm{m}^{3}$ de fibras

Os resultados obtidos para fibras de PP vão em desencontro com o encontrado por Błyszko [50] e por Aslani e Nejadi [52]. Segundo Błyszko [50], a adição dessas fibras aumenta a fluência em concretos de idades jovens, possivelmente porque cria superfícies de deslizamento adicionais. Além disso, as fibras são dúcteis, e, portanto, apresentam maior deformação. Essa deformação seria transmitida e considerada como deformação do compósito. No entanto, o autor utilizou uma dosagem de $2 \mathrm{~kg} / \mathrm{m}^{3}$ de fibras de $19 \mathrm{~mm}$ e Aslani e Nejadi [52] usou um teor de $5 \mathrm{~kg} / \mathrm{m}^{3}$ de fibras de $65 \mathrm{~mm}$. A alta dosagem de fibras e/ou o maior comprimento delas se comparado as fibras utilizadas neste ensaio pode ter aumentado o efeito de ductilidade no compósito, justificando assim um aumento na deformação por fluência. Além disso, as condições de ensaio, materiais utilizados e método de mistura dos autores e dessa pesquisa foram distintas, podendo de alguma forma justificar a diferença nos resultados.

Toledo Filho [74] observou em seus estudos uma redução na fluência básica de argamassas com fibras de sisal e coco em até $25 \%$. A fibra de coco apresentou maiores reduções da deformação do que as fibras de sisal. $\mathrm{O}$ autor sugere que esta melhora pode ter ocorrido pela aderência interfacial fibra-matriz em tração transversal. Sales [44], em contrapartida, encontrou valores significativamente altos de deformação por fluência básica em pastas de cimento com adição de polpa de bambu. No entanto, a autora observou falhas na selagem das amostras, que apresentaram perda de massa ao longo do ensaio. 
Segundo Zhao et al. [104] a estrutura interfacial do concreto tende a ficar mais fraca quando o módulo de elasticidade das fibras adicionadas na mistura é menor do que o módulo do concreto puro. Além disso, a região da matriz cimentícia no entorno da fibra tende a ser mais porosa, o que reduz a habilidade do compósito de resistir a fluência.

Os valores da aplicação de carga de cada mistura no ensaio da fluência, teórico e efetivo, estão apresentados na Tabela 4.6. De maneira geral, a carga efetiva foi menor que a carga teórica. Como o processo de aplicação da carga foi feito de forma manual, os períodos aos quais o laboratório estava fechado (durante as noites e finais de semana) ficaram sem ajuste de carga. No entanto, é possível observar pelo baixo desvio padrão das amostras que os valores de carga não apresentaram grande variabilidade. A Tabela 4.7 apresenta os valores de deformação total e por fluência obtidos ao final dos ensaios de fluência a compressão de cada mistura.

Tabela 4.6 - Valores de carga máxima resistida a compressão e carga aplicada no ensaio de fluência

\begin{tabular}{lccc}
\hline $\begin{array}{c}\text { Valores } \\
\text { em } \boldsymbol{k N}\end{array}$ & Teórica (20\%) & Efetiva & D.P. $^{{ }^{1}}$ \\
\hline Ref_LI53 & 11,32 & 10,86 & 0,57 \\
Ref_LII65 & 9,74 & 9,19 & 0,44 \\
C0,3 & 10,76 & 10,08 & 0,56 \\
C1,2 & 10,28 & 9,57 & 0,75 \\
C2,7 & 10,77 & 10,35 & 0,51 \\
PP0,3 & 11,51 & 11,82 & 0,6 \\
PP1,2 & 12,84 & 12,41 & 0,54 \\
PP2,7 & 11,43 & 10,91 & 0,61 \\
\hline
\end{tabular}

${ }^{1}$ Desvio padrão da carga efetivamente aplicada 
Tabela 4.7 - Valores de deformação total e por fluência obtidos pelo ensaio de fluência a compressão

\begin{tabular}{|c|c|c|c|c|}
\hline & \multicolumn{2}{|c|}{$\begin{array}{l}\text { Deformação total } \\
\text { (elástica + fluência) }\end{array}$} & \multicolumn{2}{|c|}{ Deformação por fluência } \\
\hline & $\mu \varepsilon^{a}$ & $\%^{b}$ & $\mu \varepsilon^{a}$ & $\%^{b}$ \\
\hline Ref_LI53 & 240 & - & 121 & - \\
\hline Ref_LII65 & 335 & $40 \%$ & 106 & $-12 \%$ \\
\hline$C 0,3$ & 237 & $-1 \%$ & 123 & $2 \%$ \\
\hline$C 1,2$ & 319 & $33 \%$ & 106 & $-12 \%$ \\
\hline$C 2,7$ & 348 & $45 \%$ & 115 & $-5 \%$ \\
\hline$P P 0,3$ & 302 & $26 \%$ & 120 & $-1 \%$ \\
\hline PP1,2 & 282 & $18 \%$ & 112 & $-7 \%$ \\
\hline$P P 2,7$ & 174 & $-28 \%$ & 100 & $-17 \%$ \\
\hline
\end{tabular}

a Valores relativos ao sétimo dia de idade

${ }^{b}$ Redução/aumento da fluência aos 7 dias em relação à referência, em \% 


\section{Conclusão e trabalhos futuros}

\subsection{Conclusão}

Ensaios de retração autógena, retração por secagem livre e com restrição, e de fluência a compressão foram realizados nesta pesquisa. Dois lotes de cimentos com variações no teor de $\mathrm{C}_{3} \mathrm{~S}$ foram utilizados. Fibras de polipropileno e curauá como reforço fibroso foram adicionadas nas pastas de cimento para avaliação do comportamento do compósito. Os resultados desses ensaios são apresentados a seguir:

(1) O comportamento das pastas com cimento dos lotes I e II foi semelhante, não havendo, assim, variação da retração autógena. Dessa forma, pode-se afirmar que a variação no teor de $\mathrm{C}_{3} \mathrm{~S}$ dentro dos limites mínimos (48\%) e máximos (65\%) estabelecidos pela ASTM 114 [92] não afetam a retração autógena.

(2) Observou-se que a adição de fibras de polipropileno em pasta de cimento reduziu a retração por secagem livre ligeiramente (em média, 8,13\%), e que a variação no teor das fibras não aparentou influenciar a redução. Dessa maneira, a adição de $0,3 \mathrm{~kg} / \mathrm{m}^{3}$ de PP seria suficiente para a redução da retração na proporção apresentada.

(3) A adição de fibras de curauá apresentou uma ligeira melhora na retração livre em cerca de $8,5 \%$ para adição de $2,7 \mathrm{~kg} / \mathrm{m}^{3}$, mas para teores menores, a retração não aparentou ser influenciada.

(4) Os resultados dos ensaios de retração com restrição mostraram que a adição de ambas as fibras nas pastas de cimento atrasou o desenvolvimento de fissuras. Este atraso foi entre 16 e 28 horas para adição de $0,3 \mathrm{~kg} / \mathrm{m}^{3}$ de curauá e $0,3 \mathrm{~kg} / \mathrm{m}^{3}$ de $P P$, respectivamente.

(5) A redução da abertura de fissuras também foi observada em todas as misturas com reforço fibroso. As pastas com adição de fibras de PP apresentaram maiores reduções na abertura das fissuras do que as com adição de curauá. $\mathrm{O}$ aumento no teor de fibras reduziu a abertura das 
fissuras. A adição de $0,3 \mathrm{~kg} / \mathrm{m}^{3}$ de PP reduziu cerca de $71 \%$ enquanto a adição de $2,7 \mathrm{~kg} / \mathrm{m}^{3}$ reduziu $91 \%$ a abertura da fissura. Para as amostras com fibras de curauá, a redução foi de 32 e $80 \%$ para adição de 0,3 e $2,7 \mathrm{~kg} / \mathrm{m}^{3}$, respectivamente.

(6) As pastas com adição de fibras exibiram, no geral, pouco influencia na deformação por fluência. O aumento no teor de fibras de PP diminuiu essa deformação ligeiramente. A adição de $0,3,1,2$ e $2,7 \mathrm{~kg} / \mathrm{m}^{3}$ de fibras de polipropileno apresentou melhora de 1, 7 e 17\% na deformação por fluência, respectivamente. A adição de 1,2 e $2,7 \mathrm{~kg} / \mathrm{m}^{3}$ de fibras de curauá reduziu em 12 e $5 \%$ a deformação por fluência, enquanto a adição de $0,3 \mathrm{~kg} / \mathrm{m}^{3}$ aumentou em $2 \%$ essa deformação. Foi observado uma variabilidade relativamente alta nas amostras de $2,7 \mathrm{~kg} / \mathrm{m}^{3}$ de PP e de 0,3 e $2,7 \mathrm{~kg} / \mathrm{m}^{3}$ de curauá.

(7) A variação de $\mathrm{C}_{3} \mathrm{~S}$ dentro dos limites estabelecidos pela ASTM 114 [92] não influenciou significativamente a deformação por fluência.

\subsection{Sugestão de trabalhos futuros}

Concluindo a análise dos resultados obtidos nesta pesquisa, e ciente da necessidade de ensaios mais aprofundados nos assuntos abordados aqui, são sugeridos, neste item, ensaios e condições de ensaios diversificados para melhor entender o comportamento desses materiais:

(1) Número maior de ensaios de retração autógena com as misturas testadas nesta pesquisa a fim de avaliar a variabilidade dos resultados.

(2) Ensaios de arrancamento das fibras de polipropileno e curauá na matriz cimentícia a fim de avaliar a influência da interface fibra-matriz tanto nos ensaios de retração quanto de fluência.

(3) Execução dos ensaios de retração e fluência para pastas com aditivos utilizados em poços de petróleo e reforçados com fibras, para avaliar o comportamento da interação desses aditivos com as fibras nos ensaios de retração e fluência.

(4) Melhora do método de aplicação de carga de fluência por meio de um sistema hidráulico para redução da perda de carga durante o período de ensaio. 
(5) Estudo da aplicação do ensaio de retração com restrição pelo método do anel em condição autógena para caracterização de pastas de poço de petróleo. Este ensaio pode ser interessante uma vez que a geometria da seção transversal da coluna de revestimento de poços de petróleo é semelhante a geometria da seção transversal do ensaio pelo método do anel.

(6) Execução dos ensaios realizados nesta pesquisa para fibras de curauá não saturadas a fim de se avaliar a diferença no comportamento das pastas com fibras saturadas e não saturadas. 


\section{Referência bibliográfica}

[1] Q. Zhang, R. Le Roy, M. Vandamme, and B. Zuber, "Long-term creep properties of cementitious materials - Comparing compression tests on concrete with microindentation tests on cement," pp. 184-190, 2013.

[2] B. Loturco, "Não é concreto nem argamassa | Téchne," 2006. [Online]. Disponível: $\quad$ techne17.pini.com.br/engenharia-civil/107/artigo2850131.aspx. [Acessado: 29-Ago-2018].

[3] Petrobras, "Pré-Sal: Produção de Petróleo e Gás Natural." [Online]. Disponível: http://www.petrobras.com.br/pt/nossas-atividades/areas-deatuacao/exploracao-e-producao-de-petroleo-e-gas/pre-sal/. [Acessado: 29Ago-2018].

[4] E. B. Nelson, Well Cementing. Texas: Schlumberger Educational Services, 1990.

[5] R. C. Smith, "Successful Primary Cementing Can Be a Reality," J. Pet. Technol., vol. 36, pp. 1851-1858, 1984.

[6] AMERICAN PETROLEUM INSTITUTE, "Recommended practice for testing well cements," API 10B, p. 56, 1997.

[7] A. A. Triggia et al., Fundamentos de Engenharia de Petróleo. Rio de Janeiro, 2001.

[8] Z. P. Bažant and F. H. Wittmann, "Mathematical models for creep and shrinkage of concrete," Creep Shrinkage Concr. Struct., pp. 163-256, 1982.

[9] D. S. Atrushi, "Tensile and compressive creep of early age concrete: testing and modelling," The Norwegian University of Science and Technology, 2003.

[10] T. Wongtanakitcharoen and A. E. Naaman, "Unrestrained early age shrinkage of concrete with polypropylene, PVA, and carbon fibers," Mater. Struct., vol. 40, no. 3, pp. 289-300, 2007.

[11] A. M. Neville, Properties of Concrete, 5th ed. England: Pearson Education Limited, 2011.

[12] AMERICAN SOCIETY FOR TESTING AND MATERIALS, "Standard 
test method for chemical shrinkage of hydraulic cement paste," ASTM C1608, p. 5, 2017.

[13] M. H. Zhang, C. T. Tam, and M. P. Leow, "Effect of water-to-cementitious materials ratio and silica fume on the autogenous shrinkage of concrete," Cem. Concr. Res., vol. 33, no. 10, pp. 1687-1694, 2003.

[14] O. M. Jensen and P. F. Hansen, “Autogenous deformation and RH-change in perspective," Cem. Concr. Res., vol. 31, no. 12, pp. 1859-1865, 2001.

[15] D. P. Bentz and O. M. Jensen, "Mitigation strategies for autogenous shrinkage cracking," Cem. Concr. Compos., vol. 26, no. 6, pp. 677-685, 2004.

[16] V. Baroghel-Bouny, "Experimental investigation of self-desiccation in highperformance materials - comparison with drying behaviour," Proc. Int. Res. Semin. Self-Desiccation Its Importance Concr. Technol., pp. 72-87, 1997.

[17] J. Zhang, Y. D. Han, and Y. Gao, "Effects of Water-Binder Ratio and Coarse Aggregate Content on Interior Humidity, Autogenous Shrinkage, and Drying Shrinkage of Concrete," J. Mater. Civ. Eng., vol. 26, no. 1, pp. 184-189, 2014.

[18] D. Saje, B. Bandelj, J. Šušteršič, J. Lopatič, and F. Saje, "Shrinkage of Polypropylene Fiber-Reinforced High-Performance Concrete," J. Mater. Civ. Eng., vol. 23, no. 7, pp. 941-952, 2011.

[19] D. Saje, B. Bandelj, J. Šušteršic, J. Lopatic, and F. Saje, “Autogenous and Drying Shrinkage of Fibre Reinforced High-Performance Concrete," J. Adv. Concr. Technol., vol. 10, no. 2, pp. 59-73, 2012.

[20] E. ichi Tazawa and S. Miyazawa, "Influence of cement and admixture on autogenous shrinkage of cement paste," Cem. Concr. Res., vol. 25, no. 2, pp. 281-287, 1995.

[21] E. Tazawa and S. Miyazawa, "Influence of constituents and composition on autogenous shrinkage of cementitious materials," 10th Int. Congr. Chem. Cem. Vol. 2, vol. c, no. 89, p. 2ii071, 1997.

[22] J. J. Brooks and M. A. Megat Johari, "Effect of metakaolin on creep and shrinkage of concrete," Cem. Concr. Compos., vol. 23, no. 6, pp. 495-502, 2001.

[23] D. Niknezhad, S. Kamali-Bernard, and C. Garand, "Influence of Mineral Admixtures (Metakaolin, Slag, Fly Ash) on the Plastic, Free, and Restrained 
Shrinkage of SCCs," Concreep 10, pp. 1157-1166, 2015.

[24] M. Mazloom, A. A. Ramezanianpour, and J. J. Brooks, "Effect of silica fume on mechanical properties of high-strength concrete," Cem. Concr. Compos., vol. 26, no. 4, pp. 347-357, 2004.

[25] O. M. Jensen, "Influence of Cement Composition on Autogenous Deformation and Change of the Relative Humidity," in Shrinkage of Concrete (Shrinkage 2000), 2000, vol. 17, no. 9, pp. 143-153.

[26] D. Saje, "Reduction of the Early Autogenous Shrinkage of High Strength Concrete," Adv. Mater. Sci. Eng., 2015.

[27] D. P. Bentz, O. M. Jensen, K. K. Hansen, J. F. Olesen, H. Stang, and C. J. Haecker, "Influence of Cement Particle-Size Distribution on Early Age Autogenous Strains and Stresses in Cement-Based Materials," J. Am. Ceram. Soc., vol. 84, no. 1, pp. 129-135, 2001.

[28] E. A. B. Koenders, "Simulation of volume changes in hardening cementbased materials," Delft University of Technology, 1997.

[29] D. P. Bentz, E. J. Garboczi, C. J. Haecker, and O. M. Jensen, "Effects of cement particle size distribution on performance properties of Portland cement-based materials," Cem. Concr. Res., vol. 29, no. 10, pp. 1663-1671, 1999.

[30] E. W. Bennett and D. R. Loat, "Shrinkage and creep of concrete as affected by the fineness of Portland cement," Mag. Concr. Res., vol. 22, no. 71, pp. 69-78, 1970.

[31] P. Gao, T. Zhang, R. Luo, J. Wei, and Q. Yu, "Improvement of autogenous shrinkage measurement for cement paste at very early age: Corrugated tube method using non-contact sensors," Constr. Build. Mater., vol. 55, pp. 57$62,2014$.

[32] V. Baroghel-Bouny, P. Mounanga, A. Khelidj, A. Loukili, and N. Rafaï, "Autogenous deformations of cement pastes: Part II. W/C effects, micromacro correlations, and threshold values," Cem. Concr. Res., vol. 36, no. 1, pp. 123-136, 2006.

[33] D. P. Bentz, M. A. Peltz, and J. Winpigler, "Early-age properties of cementbased materials. II: Influence of water-to-cement ratio," J. Mater. Civ. Eng., vol. 21, no. 9, pp. 512-517, 2009.

[34] S. Zhutovsky and K. Kovler, "Influence of water to cement ratio on the 
efficiency of internal curing of high-performance concrete," Constr. Build. Mater., vol. 144, pp. 311-316, 2017.

[35] S. I. Igarashi, A. Bentur, and K. Kovler, "Autogenous shrinkage and induced restraining stresses in high-strength concretes," Cem. Concr. Res., vol. 30, no. 11, pp. 1701-1707, 2000.

[36] N. Yousefieh, A. Joshaghani, E. Hajibandeh, and M. Shekarchi, "Influence of fibers on drying shrinkage in restrained concrete," Constr. Build. Mater., vol. 148, pp. 833-845, 2017.

[37] S. Daneti and T. Wee, "Effect of polypropylene fibres on the shrinkage cracking behaviour of lightweight concrete," Mag. Concr. Res., vol. 63, no. 11, pp. 871-881, 2011.

[38] T. Aly and J. G. Sanjayan, "Shrinkage-cracking behavior of OPC-fiber concrete at early-age,” Mater. Struct., vol. 43, no. 6, pp. 755-764, 2010.

[39] X. S. Xie, F. Tian, and Y. H. Hong, "Experimental Investigation into the Impact of Polypropylene Fibers and SRA on the Early Crack Resistance of Concrete," Adv. Mater. Res., vol. 194-196, pp. 858-864, 2011.

[40] P. Zhang and Q. F. Li, "Combined effect of silica fume and polypropylene fiber on drying shrinkage properties of concrete composites containing fly ash,” Sci. Iran., vol. 20, no. 5, pp. 1372-1380, 2013.

[41] N. Buch, "Impact of Processed Cellulose Fibers on Portland Cement Concrete Properties," Transp. Res. Rec., vol. 1668, no. 1, pp. 72-80, 1999.

[42] S. Kawashima and S. P. Shah, "Early-age autogenous and drying shrinkage behavior of cellulose fiber-reinforced cementitious materials," Cem. Concr. Compos., vol. 33, no. 2, pp. 201-208, 2011.

[43] J. R. Rapoport and S. P. Shah, "Cast-in-Place Cellulose Fiber-Reinforced Cement Paste , Mortar, and Concrete," ACI Mater. J., vol. 102, no. 5, pp. 299-306, 2005.

[44] A. T. C. Sales, "Retração, fluência e fratura em compósitos cimentícios reforçados com polpa de bambu," Pontifícia Universidade Católica do Rio de Janeiro, 2006.

[45] R. D. Toledo Filho, K. Ghavami, M. A. Sanjuán, and G. L. England, "Free, restrained and drying shrinkage of cement mortar composites reinforced with vegetable fibres," Cem. Concr. Compos., vol. 27, no. 5, pp. 537-546, 2005.

[46] W. N. Findley, J. S. Lai, and K. Onaran, Creep and relaxation of nonlinear 
viscoelastic materials, Dover. New York: Dover Publications, 1989.

[47] I. Fischer, B. Pichler, E. Lach, C. Terner, E. Barraud, and F. Britz, "Compressive strength of cement paste as a function of loading rate: Experiments and engineering mechanics analysis," Cem. Concr. Res., vol. 58, pp. 186-200, 2014.

[48] P. K. Mehta and P. J. M. Monteiro, Concrete: Microstructure, Properties, and Materials, 3th ed. McGraw-Hill, 2005.

[49] J. Byfors, "Plain concrete at early ages," Royal Institute of Technology, 1980 .

[50] J. Błyszko, "Comparative Analysis of Creep in Standard and Fibre Reinforced Concretes under different Load Conditions," Procedia Eng., vol. 193, pp. 478-485, 2017.

[51] K. Chia, X. Liu, J. R. Liew, and M. Zhang, "Experimental Study on Creep and Shrinkage of High- Performance Ultra Lightweight Cement Composite of 60MPa," Struct. Eng. Mech., vol. 50, no. 5, pp. 635-652, 2014.

[52] F. Aslani and S. Nejadi, "Creep and Shrinkage of Self-Compacting Concrete with and without Fibers," J. Adv. Concr. Technol., vol. 11, no. 10, pp. 251265, 2013.

[53] A. Sprince, A. Korjakins, and L. Pakrastinsh, "Time-Dependent Behavior of High Performance Fiber-Reinforced Concrete," Adv. Mater. Res., vol. 705, no. June, pp. 75-80, 2013.

[54] D. Spůra, J. Vodička, and M. Abramowicz, "Volume Changes of Fibre Concrete with Steel and Synthetic Fibres," Brittle Matrix Compos. 8, vol. C, pp. 285-292, 2007.

[55] J.-C. Chern and C.-H. Young, "Compressive creep and shrinkage of steel fibre reinforced concrete," Int. J. Cem. Compos. Light. Concr., vol. 11, no. 4, pp. 205-214, 1989.

[56] A. K. Niyogi, P. Hsu, and B. L. Meyers, "The Influence of Age at Time of Loading on Basic and Drying Creep," Cem. Concr. Res., vol. 3, no. 5, pp. 633-644, 1973.

[57] M. Irfan-Ul-Hassan, B. Pichler, R. Reihsner, and C. Hellmich, "Elastic and creep properties of young cement paste, as determined from hourly repeated minute-long quasi-static tests," Cem. Concr. Res., vol. 82, pp. 36-49, 2016.

[58] W. Jiang, G. De Schutter, and Y. Yuan, "Degree of hydration based 
prediction of early age basic creep and creep recovery of blended concrete," Cem. Concr. Compos., vol. 48, pp. 83-90, 2014.

[59] T. Vidal, A. Sellier, W. Ladaoui, and X. Bourbon, "Effect of Temperature on the Basic Creep of High-Performance Concretes Heated between 20 and 80 C," J. Mater. Civ. Eng., vol. 27, no. 7, pp. 1-7, 2015.

[60] B. T. Tamtsia, J. J. Beaudoin, and J. Marchand, "The early age short-term creep of hardening cement paste: Load-induced hydration effects," Cem. Concr. Compos., vol. 26, no. 5, pp. 481-489, 2004.

[61] R. S. Ghosh, "Creep of portland cement paste at early ages," Mater. Struct., vol. 5, no. 26, pp. 93-97, 1972.

[62] A. Leemann, P. Lura, and R. Loser, "Shrinkage and creep of SCC - The influence of paste volume and binder composition," Constr. Build. Mater., vol. 25, no. 5, pp. 2283-2289, 2011.

[63] G. Schutter and L. Taerwe, "Fictitious degree of hydration method for the basic creep of early age concrete," Mater. Struct., vol. 33, no. 6, pp. 370$380,2000$.

[64] L. Sorelli, J. Frech-Baronet, and J.-P. Charron, "Creep Behavior of Cement Paste, Mortar, and Concrete: The Role of Relative Humidity and Interface Porosity," no. 2014, pp. 270-279, 2015.

[65] M. Briffaut, F. Benboudjema, J. M. Torrenti, and G. Nahas, "Concrete early age basic creep: Experiments and test of rheological modelling approaches," Constr. Build. Mater., vol. 36, pp. 373-380, 2012.

[66] J. Němeček, "Creep effects in nanoindentation of hydrated phases of cement pastes," Mater. Charact., vol. 60, no. 9, pp. 1028-1034, 2009.

[67] L. J. Parrott, "An examination of the effects of age at loading upon the creep of hardened cement paste," Mag. Concr. Res., vol. 25, no. 85, pp. 197-200, 1973.

[68] M. Wyrzykowski and P. Lura, "RH Dependence upon Applied Load: Experimental Study on Water Redistribution in the Microstructure at Loading," no. 2014, pp. 270-279, 2015.

[69] J. Frech-Baronet, L. Sorelli, and J. P. Charron, "New evidences on the effect of the internal relative humidity on the creep and relaxation behaviour of a cement paste by micro-indentation techniques," Cem. Concr. Res., vol. 91, pp. 39-51, 2017. 
[70] Z. P. Bazant, A. A. Asghari, and J. Schmidt, "Experimental study of creep of hardened Portland cement paste at variable water content," Mater. Struct., vol. 9, no. 52, pp. 279-290, 1976.

[71] S. Arthanari and C. W. Yu, "Creep of concrete under uniaxial and biaxial stresses at elevated temperatures," Mag. Concr. Res., vol. 19, no. 3, pp. 149$156,1967$.

[72] European Standards, "Cement - Part 1: Composition, specifications and conformity criteria for common cements," NEN-EN 197-1, 2011.

[73] H. S. Ramaswamy, B. M. Ahuja, and S. Krishnamoorthy, "Behaviour of concrete reinforced with jute, coir and bamboo fibres," Int. J. Cem. Compos. Light. Concr., vol. 5, no. 1, pp. 3-13, 1983.

[74] R. D. T. Filho, "Materiais compósitos reforçados com fibras naturais: caracterização experimental,” Pontifícia Universidade Católica do Rio de Janeiro, 1997.

[75] P. S. Mangat and M. M. Azari, "Compression creep behaviour of steel fibre reinforced cement composites," Mater. Struct., vol. 19, no. 113, pp. 361$370,1986$.

[76] P. S. Mangat and M. M. Azari, "A theory for the creep of steel fibre reinforced cement matrices under compression," Mater. Sci., vol. 20, pp. 1119-1133, 1985.

[77] I. Korneeva, S. Neutov, and M. Suriyaninov, "Experimental studies of fiber concrete creep," vol. 02021, pp. 1-6, 2017.

[78] P. Rossi, J. P. Charron, M. Bastien-Masse, J. L. Tailhan, F. Le Maou, and S. Ramanich, "Tensile basic creep versus compressive basic creep at early ages: Comparison between normal strength concrete and a very high strength fibre reinforced concrete," Mater. Struct., vol. 47, no. 10, pp. 1773-1785, 2014.

[79] E. Marangon, R. Toledo Filho, and E. M. . Fairbairn, "Basic Creep under Compression and Direct Tension Loads of Self-compacting-steel Fibers Reinforced Concrete," RILEM, vol. 6, pp. 171-178, 2012.

[80] B. Miao, J. Chern, and C. Yang, "Influences of fiber content on properties of self-compacting steel fiber reinforced concrete," J. Chinese Inst. Eng., vol. 26, no. 4, pp. 523-530, 2003.

[81] G. T. Truong, K.-K. Choi, and O.-C. Choi, "Tensile and Compressive Creep Behaviors of Amorphous Steel Fiber-Reinforced Concrete," J. Korean 
Recycl. Constr. Resour. Inst., vol. 1, no. 3, pp. 197-203, 2013.

[82] J. Zhang, "Modeling of the influence of fibers on creep of fiber reinforced cementitious composite," Compos. Sci. Technol., vol. 63, no. 13, pp. 18771884, 2003.

[83] L. O. de Souza, "Mecanismos de fissuração e autocicatrização de compósitos cimentícios reforçados com tecido de curauá," Pontifícia Universidade Católica do Rio de Janeiro, 2017.

[84] D. L. Kantro, "Influence of Water-Reducing Admixtures on Properties of Cement Paste - A Miniature Slump Test," Cem. Concr. Aggregates, vol. 2, no. 2, pp. 95-102, 1980.

[85] Associação Brasileira de Normas Técnicas, "Cimento Portland Determinação dos tempos de pega," NBR 16607, p. 4, 2017.

[86] AMERICAN SOCIETY FOR TESTING AND MATERIALS, "Standard test method for autogenous strain of cement paste and mortar," ASTM C1698, p. 8, 2014.

[87] M. Wyrzykowski, Z. Hu, S. Ghourchian, K. Scrivener, and P. Lura, "Corrugated tube protocol for autogenous shrinkage measurements: review and statistical assessment," Mater. Struct., vol. 50, no. 1, pp. 1-14, 2017.

[88] AMERICAN SOCIETY FOR TESTING AND MATERIALS, "Standard practice for use of apparatus for the determination of length change of hardened cement paste, mortar, and concrete," ASTM C490. p. 5, 2017.

[89] AMERICAN SOCIETY FOR TESTING AND MATERIALS, "Standard Test Method for Determining Age at Cracking and Induced Tensile Stress," ASTM C1581, p. 7, 2016.

[90] Associação Brasileira de Normas Técnicas, "Cimento Portland Determinação da resistência à compressão,” NBR 7215, p. 8, 1996.

[91] AMERICAN SOCIETY FOR TESTING AND MATERIALS, "Standard test method for creep of concrete in compression," ASTM C512, p. 5, 2002.

[92] AMERICAN SOCIETY FOR TESTING AND MATERIALS, "Standard test methods for chemical analysis of hydraulic cement," ASTM C114, p. 33, 2018.

[93] S. R. Ferreira, F. de A. Silva, P. R. L. Lima, and R. D. Toledo Filho, "Effect of hornification on the structure, tensile behavior and fiber matrix bond of sisal, jute and curauá fiber cement based composite systems," Constr. Build. 
Mater., vol. 139, pp. 551-561, 2017.

[94] P. S. Mangat and M. M. Azari, "A theory for the free shrinkage of steel fibre reinforced cement matrices," Mater. Sci., vol. 19, pp. 2183-2194, 1984.

[95] H. R. Shah and J. Weiss, "Quantifying shrinkage cracking in fiber reinforced concrete using the ring test," Mater. Struct., vol. 39, no. 293, pp. 887-899, 2006.

[96] H. T. See, E. K. Attiogbe, and M. a. Miltenberger, "Potential for Restrained Shrinkage Cracking of Concrete and Mortar," Cem. Concr. Aggregates, vol. 26, no. 2, pp. 1-8, 2004.

[97] A. Bentur and S. Mindess, Fibre reinforced cementitious composites, 2nd ed. United States and Canada: Taylor \& Francis, 2007.

[98] H. Ye, "Creep Mechanisms of Calcium-Silicate-Hydrate: An Overview of Recent Advances and Challenges," Int. J. Concr. Struct. Mater., vol. 9, no. 4, pp. 453-462, 2015.

[99] H. M. Jennings, "A model for the microstructure of calcium silicate hydrate in cement paste," Cem. Concr. Res., vol. 30, no. 1, pp. 101-116, 2000.

[100] J. Sanahuja, L. Dormieux, and G. Chanvillard, "Modelling elasticity of a hydrating cement paste," Cem. Concr. Res., vol. 37, no. 10, pp. 1427-1439, 2007.

[101] J. Sanahuja and L. Dormieux, "Creep of a C-S-H gel: a micromechanical approach," An. Acad. Bras. Cienc., vol. 82, no. 1, pp. 25-41, 2010.

[102] S. Goñi et al., "Quantitative study of hydration of C3S and C2S by thermal analysis,” J. Therm. Anal. Calorim., vol. 102, no. 3, pp. 965-973, 2010.

[103] J. J. Thomas, A. J. Allen, and H. M. Jennings, "Hydration Kinetics and Microstructure Development of Normal and $\mathrm{CaCl} 2$-Accelerated Tricalcium Silicate Pastes," J. Phys. Chem. C, vol. 113, no. 46, pp. 19836-19844, 2009.

[104] Q. Zhao, J. Yu, G. Geng, J. Jiang, and X. Liu, "Effect of fiber types on creep behavior of concrete," Constr. Build. Mater., vol. 105, pp. 416-422, 2016. 


\section{Apêndice A}

A programação do Arduino Uno e do Labview para leitura automática dos relógios comparadores utilizados no ensaio de retração autógena são apresentados a seguir.

$$
\begin{aligned}
& \text { int req }=5 ; \\
& \text { int dat }=2 ; \\
& \text { int } \mathrm{clk}=3 \text {; } \\
& \text { int } \mathrm{i}=0 ; \\
& \text { int } \mathrm{j}=0 ; \\
& \text { int } \mathrm{k}=0 ; \\
& \text { int signCh }=8 \text {; } \\
& \text { int sign }=0 ; \\
& \text { int decimal; } \\
& \text { float dpp; } \\
& \text { int units; }
\end{aligned}
$$

byte mydata[14];

String value_str;

long value_int;

float value;

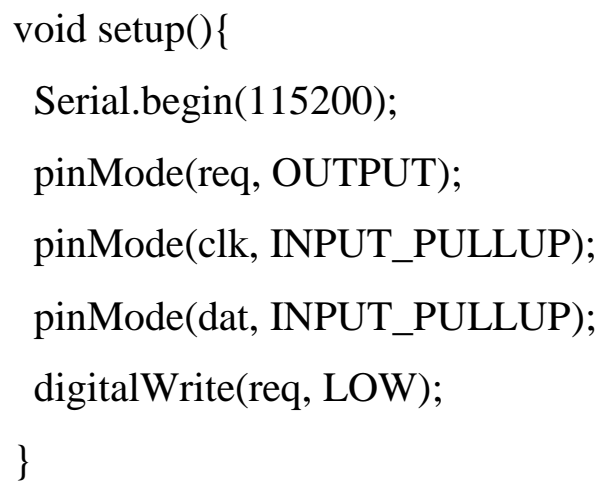




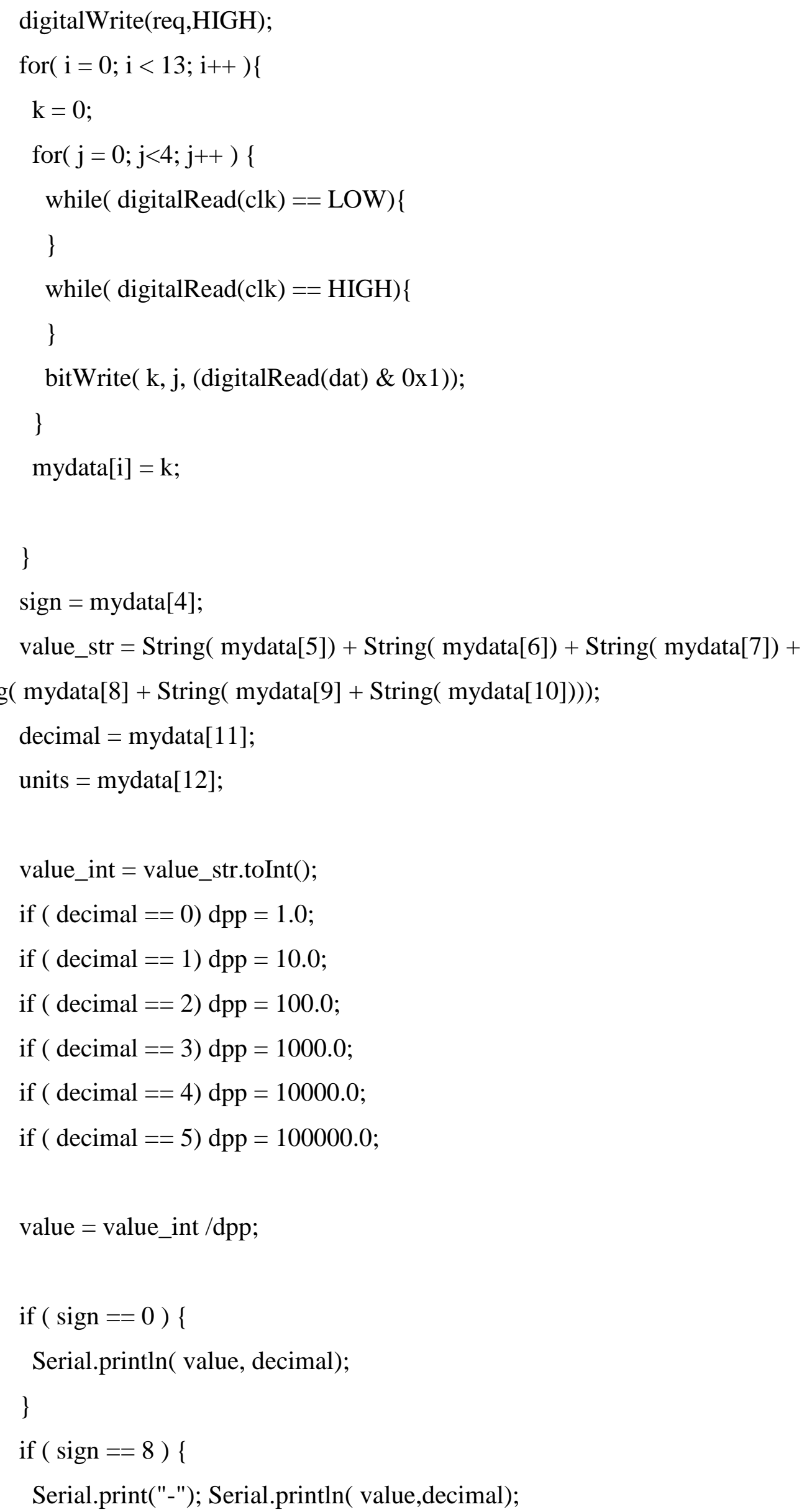


\}

digitalWrite( req, LOW);

delay( 500);

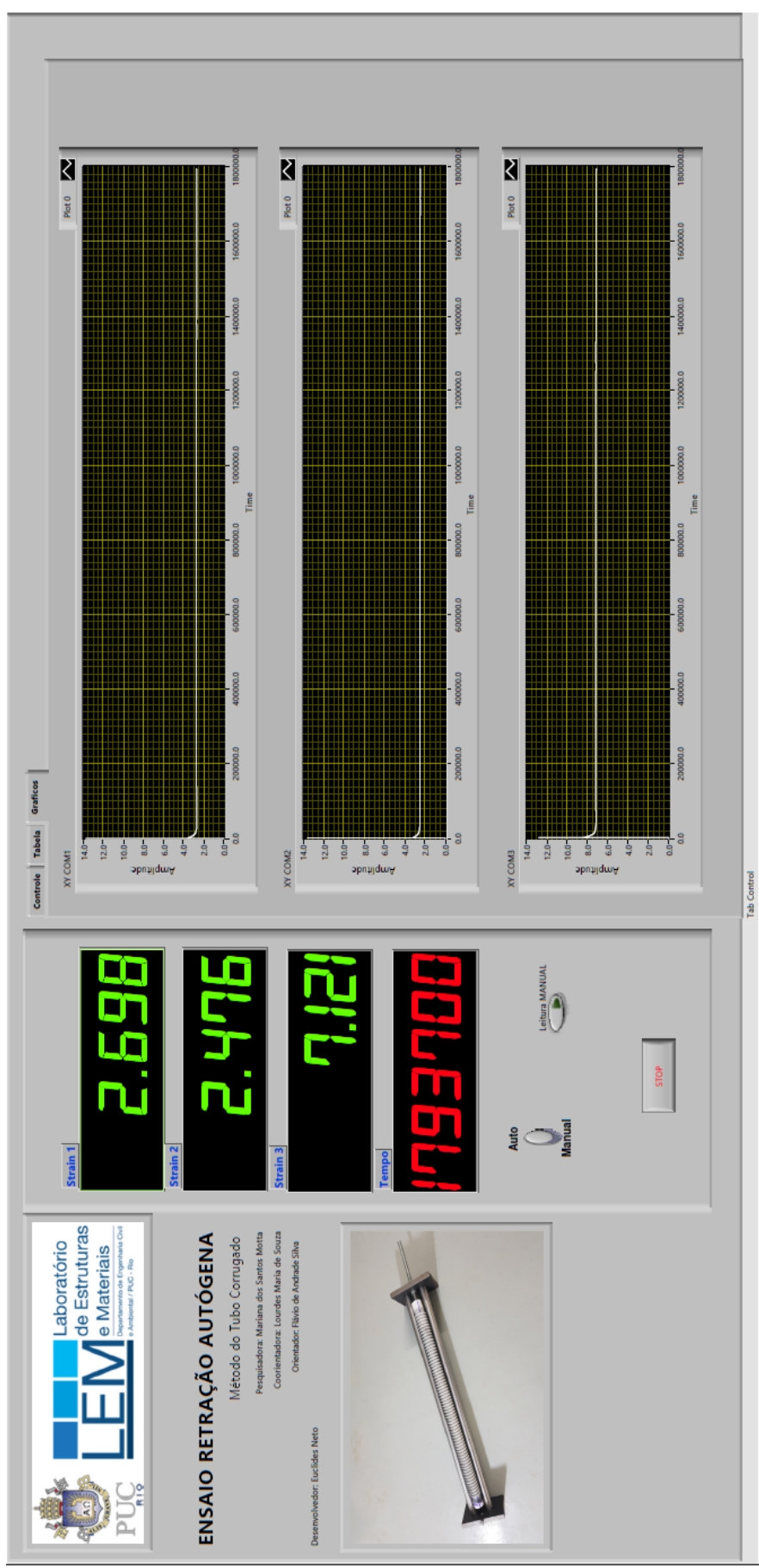

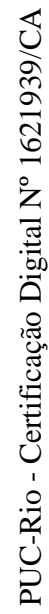
\} 


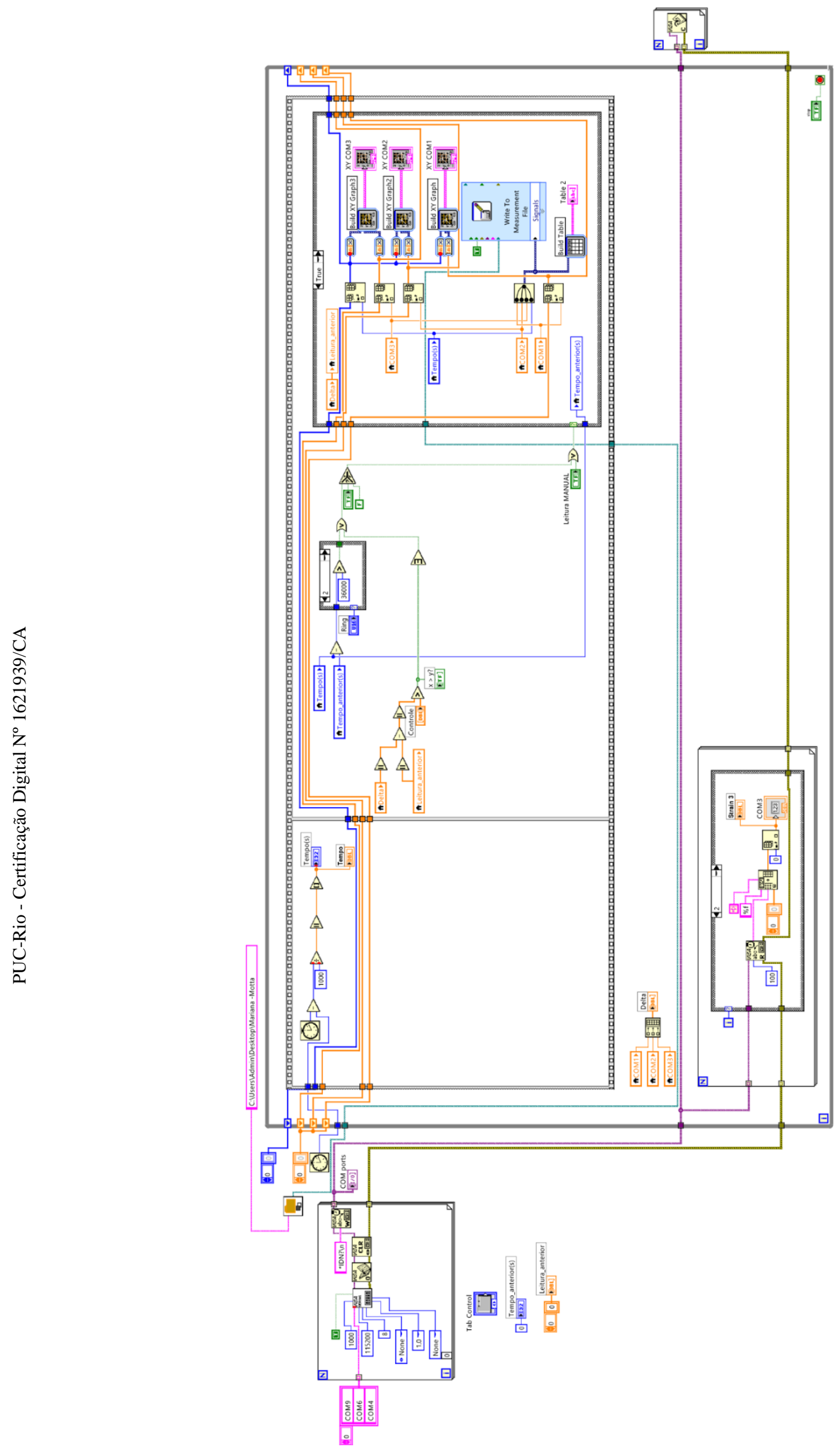




\section{Apêndice B}

\section{B.1. Ensaio de retração por secagem livre}

Esta seção apresenta os gráficos da deformação por retração livre obtida pela variação de comprimento dos corpos de prova e suas respectivas médias. É possível observar que alguns corpos de prova apresentam comportamento muito semelhante e, portanto, aparecem sobrepostos nos gráficos.

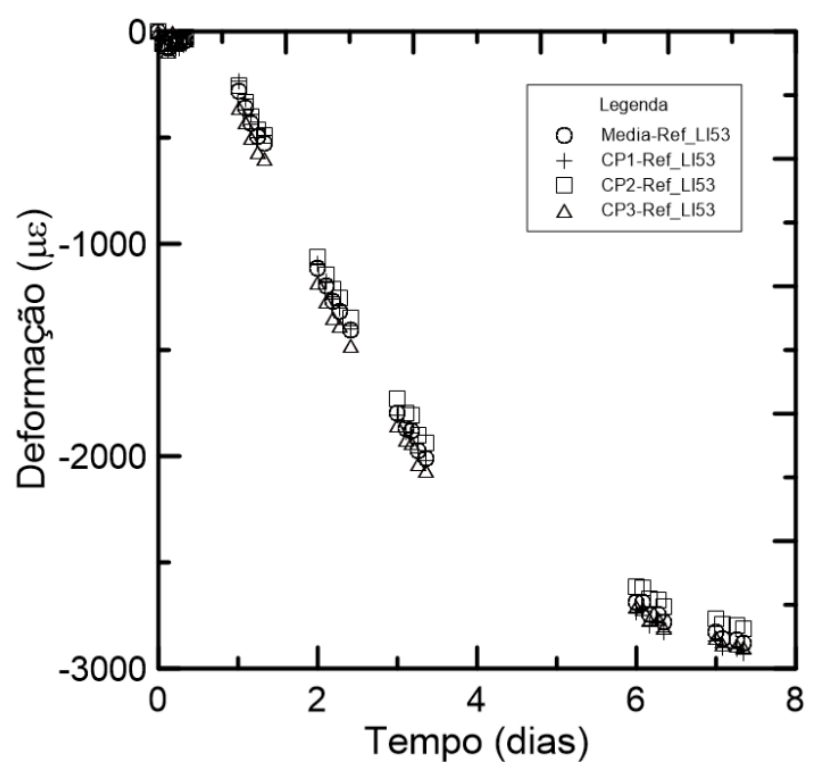

Figura 0.1 - Gráfico da deformação por retração livre dos corpos de prova de referência lote I 


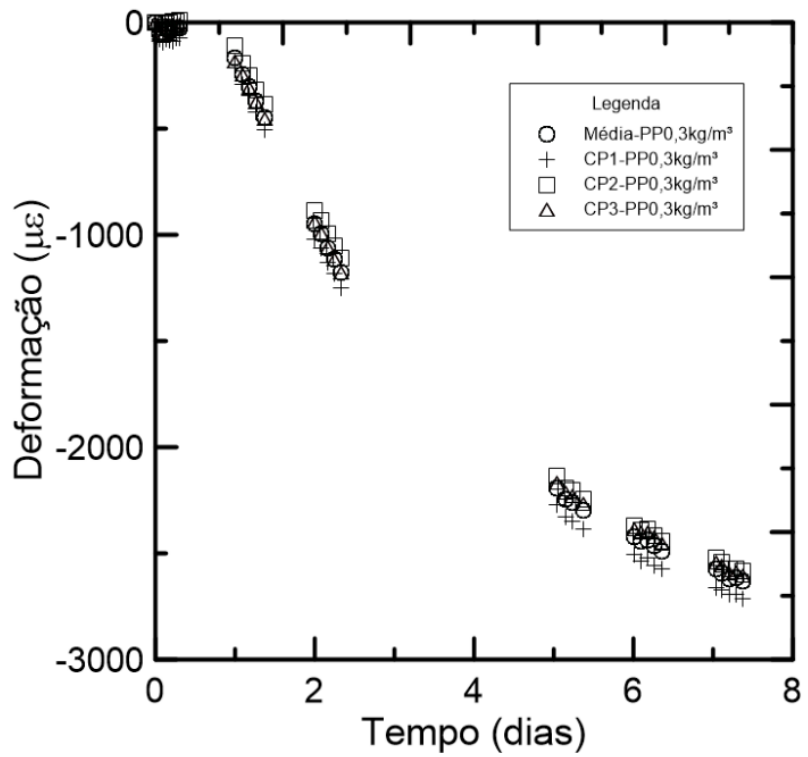

Figura 0.2 - Gráfico da deformação por retração livre dos corpos de prova de polipropileno $0,3 \mathrm{~kg} / \mathrm{m}^{3}$

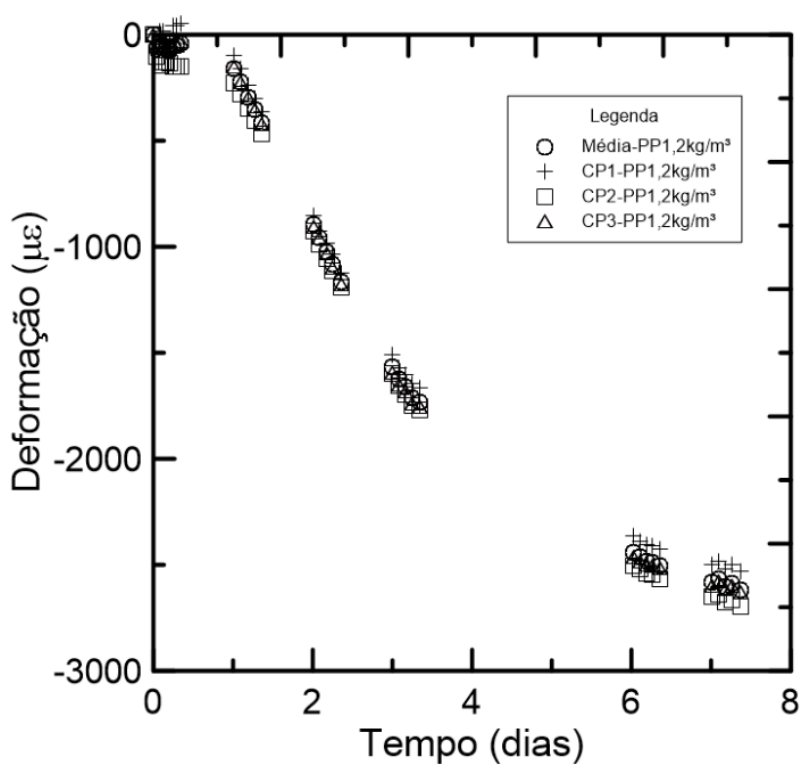

Figura 0.3 - Gráfico da deformação por retração livre dos corpos de prova de polipropileno $1,2 \mathrm{~kg} / \mathrm{m}^{3}$ 


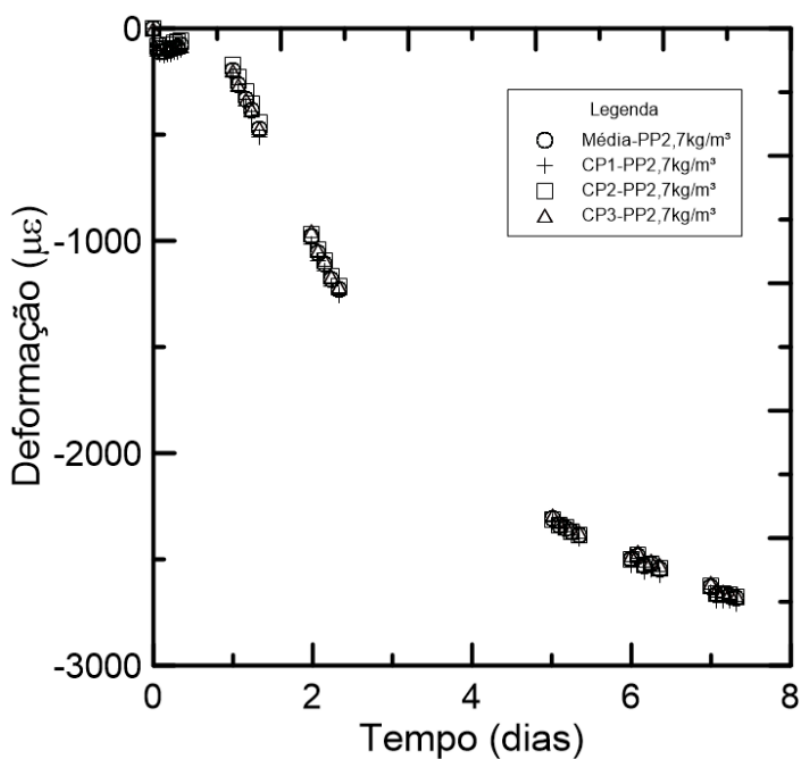

Figura 0.4 - Gráfico da deformação por retração livre dos corpos de prova de polipropileno $2,7 \mathrm{~kg} / \mathrm{m}^{3}$

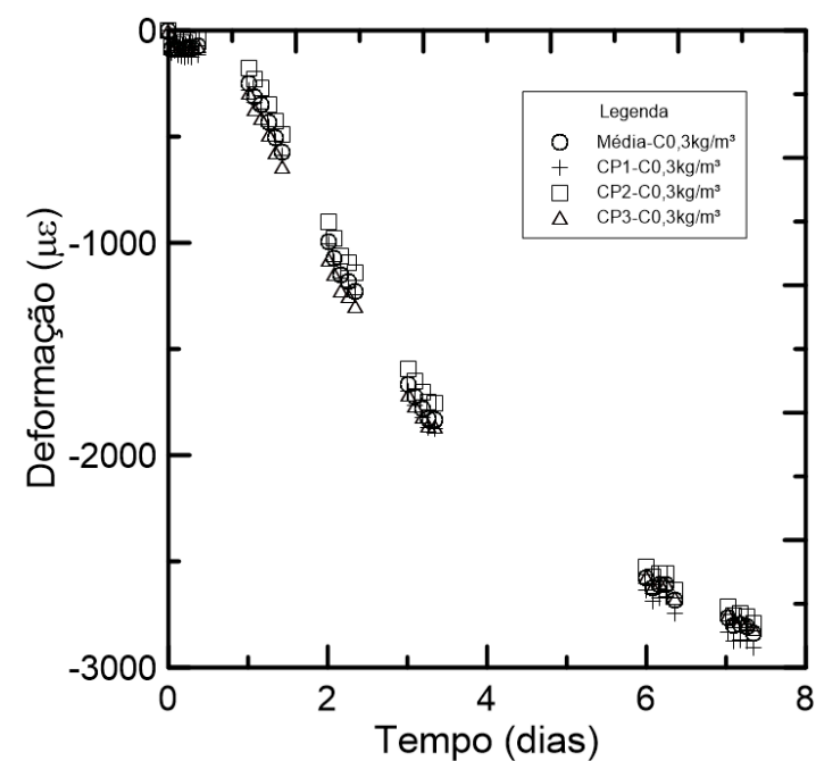

Figura 0.5 - Gráfico da deformação por retração livre dos corpos de prova de curauá $0,3 \mathrm{~kg} / \mathrm{m}^{3}$ 


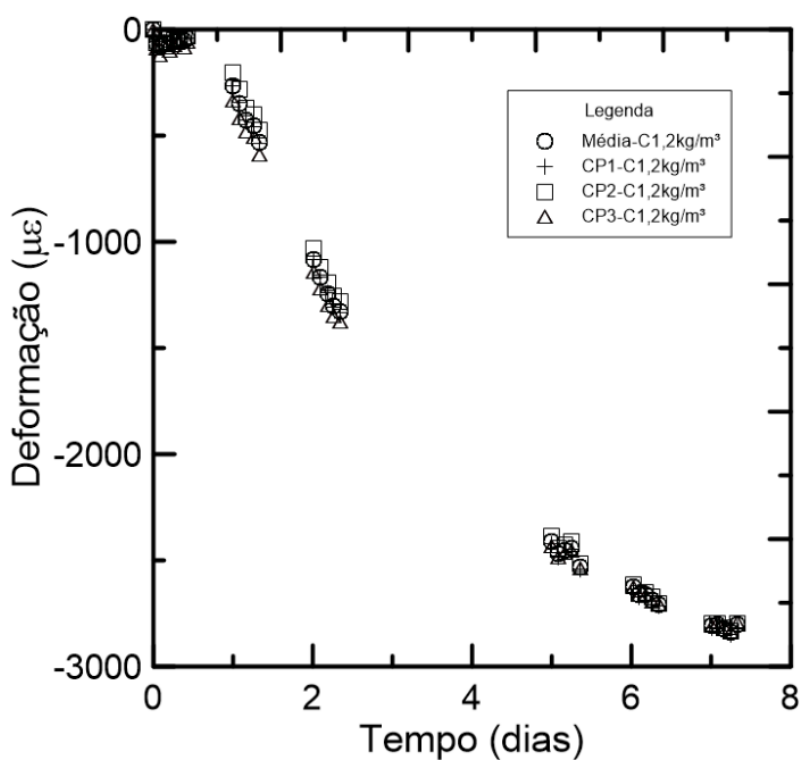

Figura 0.6 - Gráfico da deformação por retração livre dos corpos de prova de curauá $1,2 \mathrm{~kg} / \mathrm{m}^{3}$

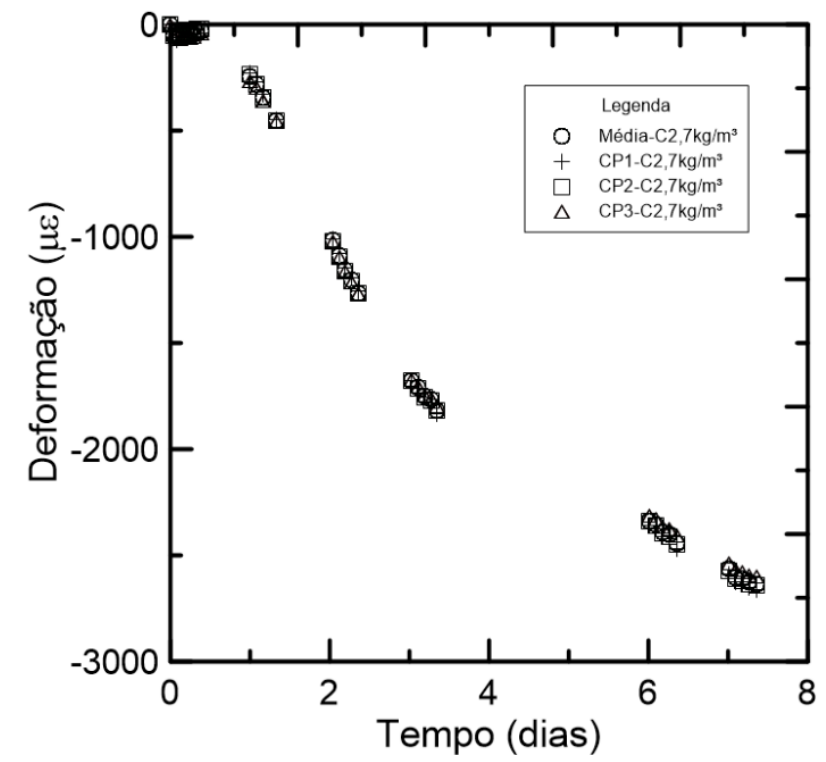

Figura 0.7 - Gráfico da deformação por retração livre dos corpos de prova de curauá $2,7 \mathrm{~kg} / \mathrm{m}^{3}$

\section{B.2. Ensaio de retração por secagem com restrição}

Esta seção apresenta os gráficos da deformação lida pelos três extensômetros no anel de aço do ensaio de retração com restrição para cada mistura. Devido a problemas na leitura da deformação, alguns extensômetros foram desconsiderados. Os gráficos de deformação média a partir da desmoldagem (início da secagem) versus raiz quadrada do tempo de cada amostra ensaiada também estão apresentados aqui. 


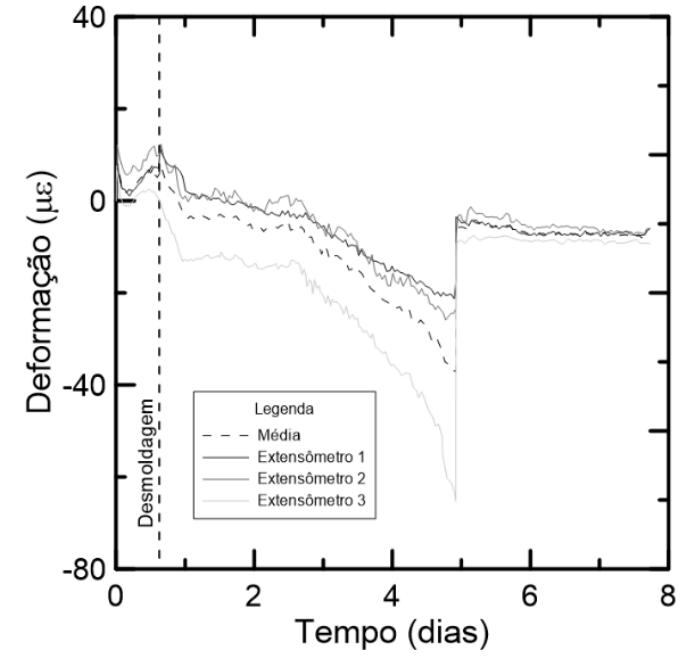

(a)

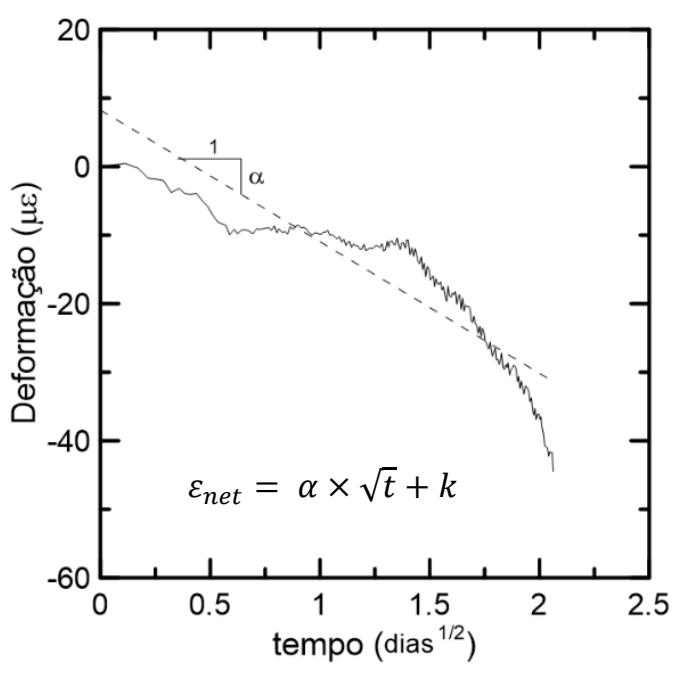

(b)

Figura 0.8 - Gráficos dos ensaios de retração com restrição: (a) Desenvolvimento da deformação do anel de referência lote II; (b) Deformação média versus raiz quadrada do tempo

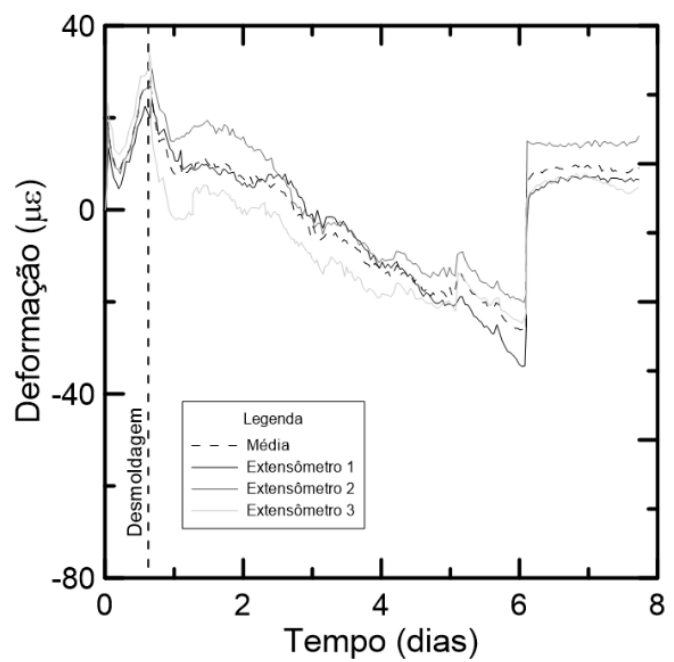

(a)

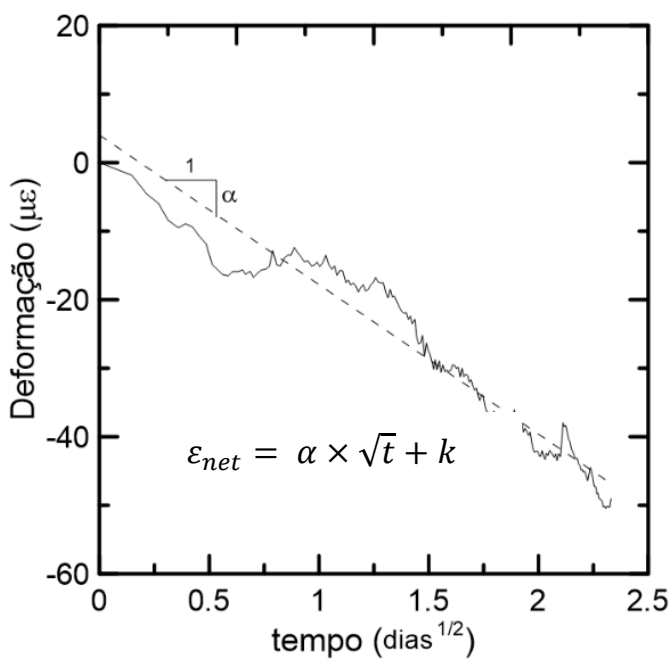

(b)

Figura 0.9 - Gráficos dos ensaios de retração com restrição: (a) Desenvolvimento da deformação do anel de PP0,3 kg/m³; (b) Deformação média versus raiz quadrada do tempo 


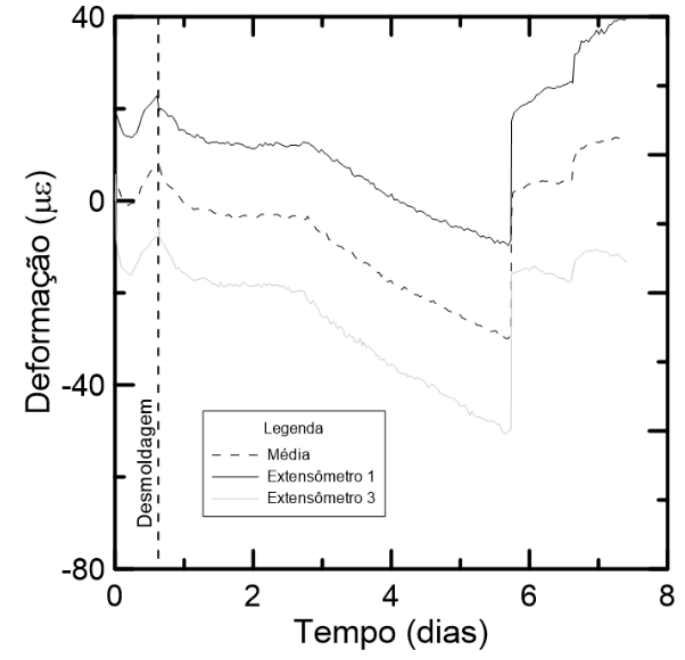

(a)

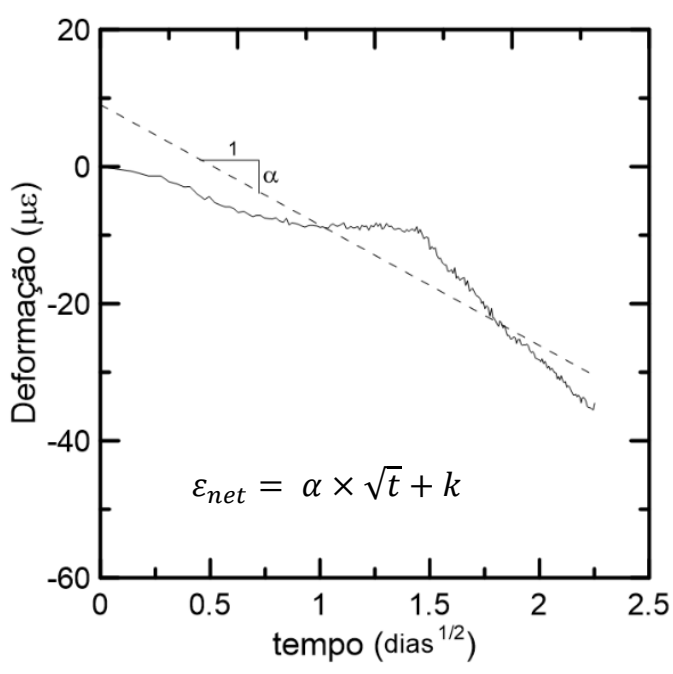

(b)

Figura 0.10 - Gráficos dos ensaios de retração com restrição: (a) Desenvolvimento da deformação do anel de PP1,2 kg/m³; (b) Deformação média versus raiz quadrada do tempo

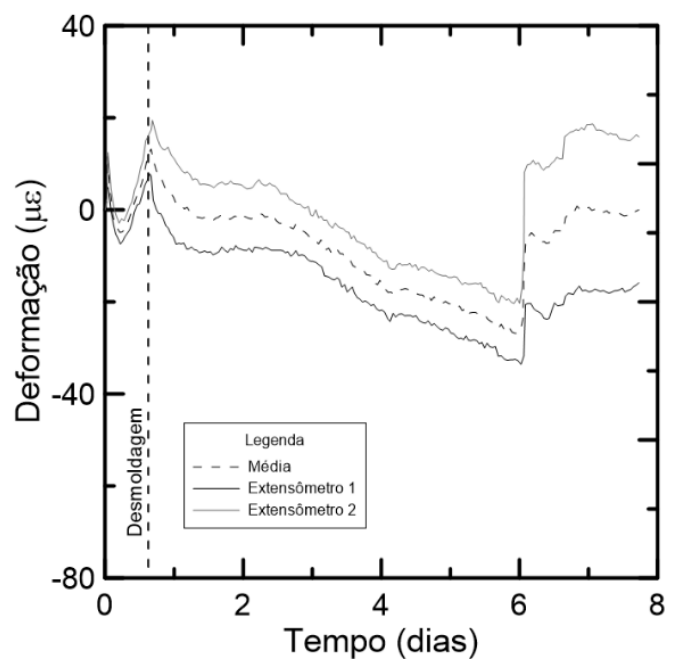

(a)

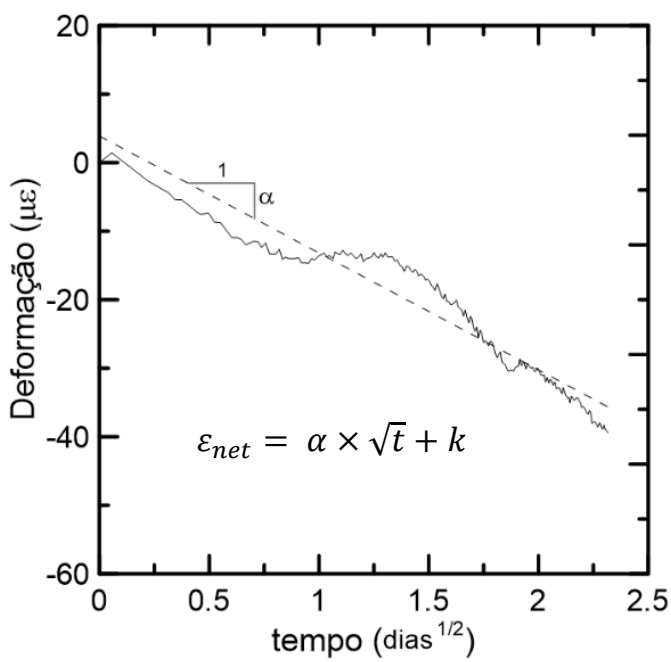

(b)

Figura 0.11 - Gráficos dos ensaios de retração com restrição: (a) Desenvolvimento da deformação do anel de PP2,7 kg/m³; (b) Deformação média versus raiz quadrada do tempo 


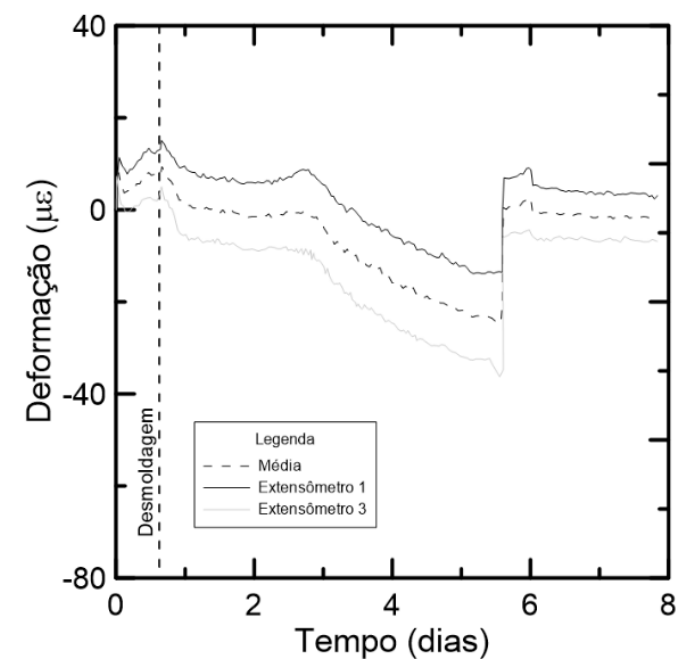

(a)

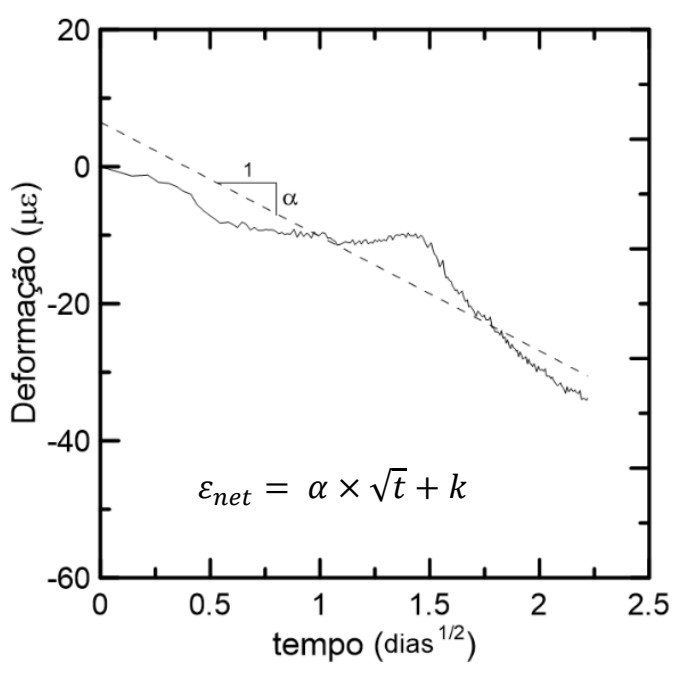

(b)

Figura 0.12 - Gráficos dos ensaios de retração com restrição: (a) Desenvolvimento da deformação do anel de curauá $0,3 \mathrm{~kg} / \mathrm{m}^{3}$; (b) Deformação média versus raiz quadrada do tempo

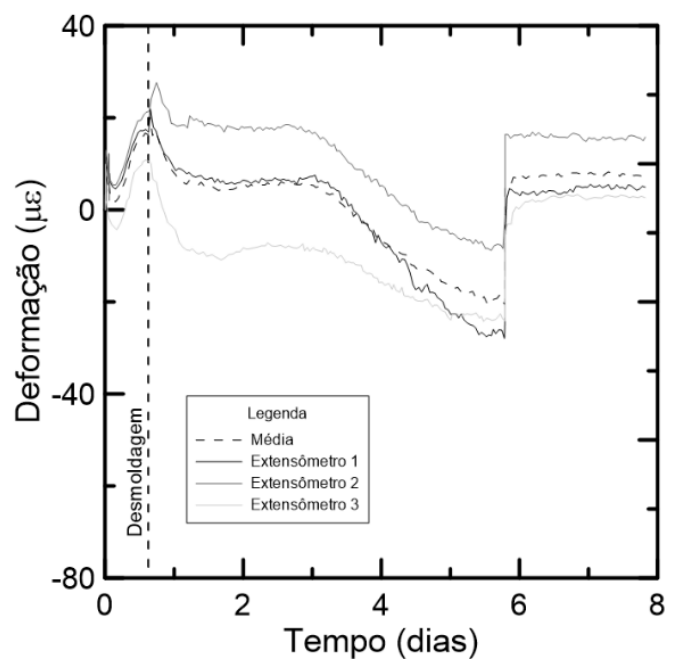

(a)

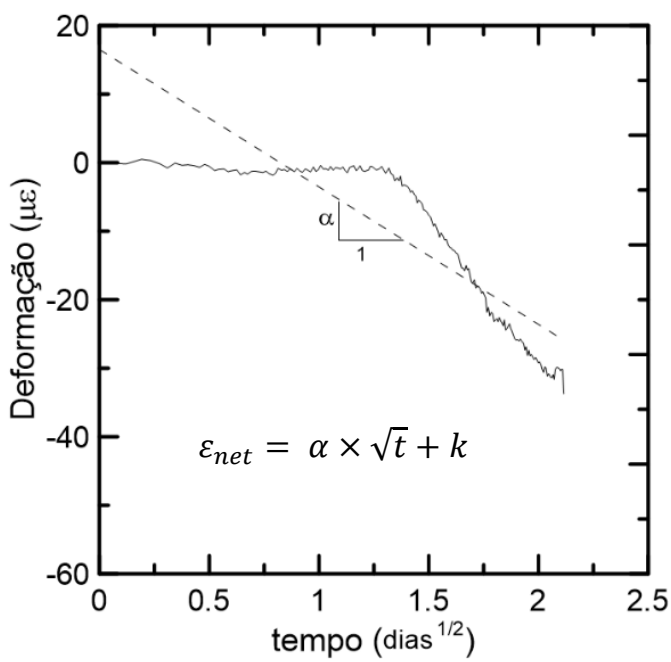

(b)

Figura 0.13 - Gráficos dos ensaios de retração com restrição: (a) Desenvolvimento da deformação do anel de curauá $1,2 \mathrm{~kg} / \mathrm{m}^{3}$; (b) Deformação média versus raiz quadrada do tempo 


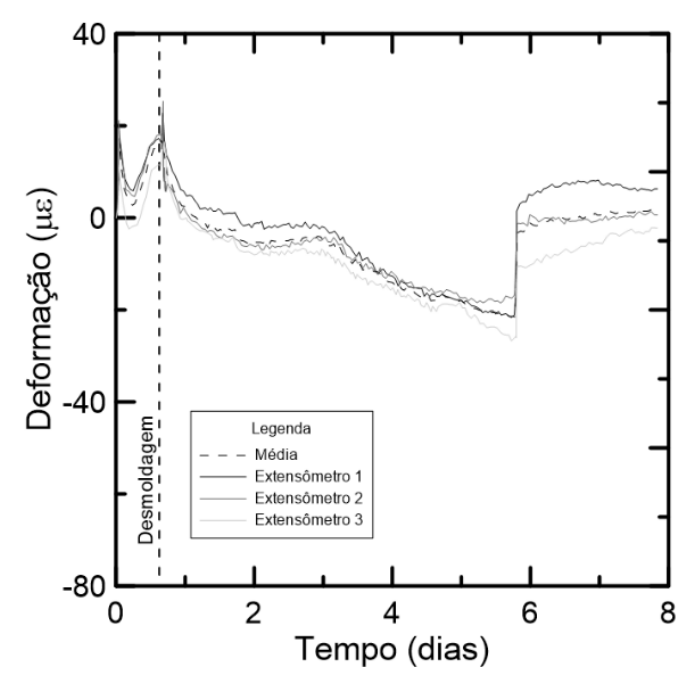

(a)

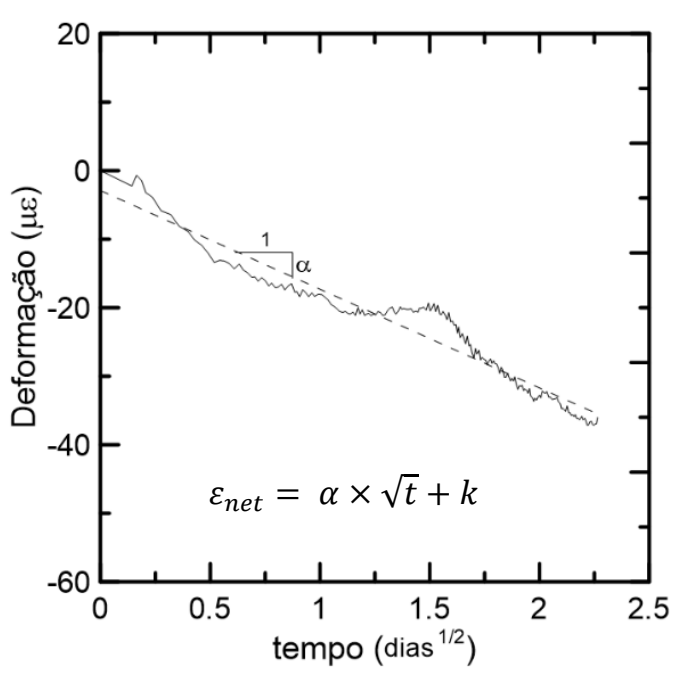

(b)

Figura 0.14 - Gráficos dos ensaios de retração com restrição: (a) Desenvolvimento da deformação do anel de curauá $2,7 \mathrm{~kg} / \mathrm{m}^{3}$; (b) Deformação média versus raiz quadrada do tempo

\section{B.3. Ensaio de fluência a compressão}

Esta seção apresenta os gráficos complementares as discussões do item 4.3 do capítulo 4. Nos gráficos estão plotados o comportamento de deformação por carga de compressão constante de cada corpo de prova e a média para cada mistura. Devido a problemas na leitura da deformação, alguns extensômetros foram desconsiderados.

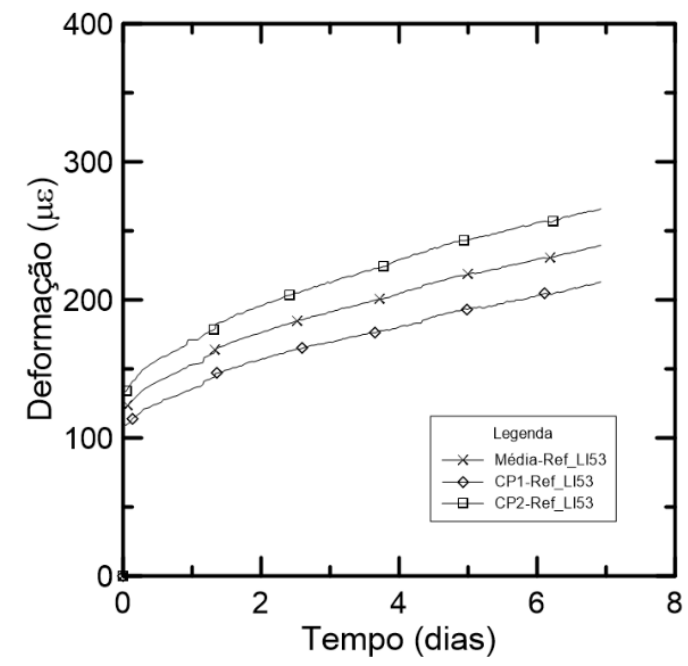

(a)

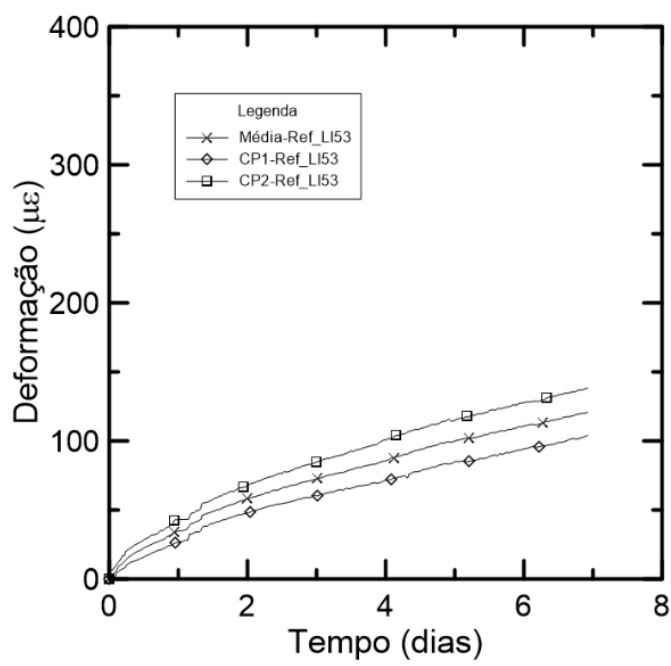

(b)

Figura 0.15 - Deformação por fluência básica: (a) deformação total e (b) sem deformação elástica dos corpos de prova de referência com cimento lote I 


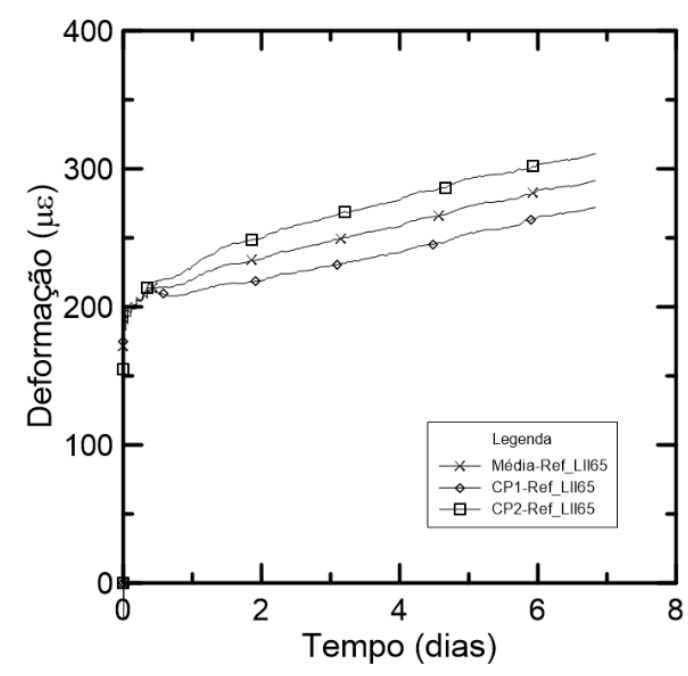

(a)

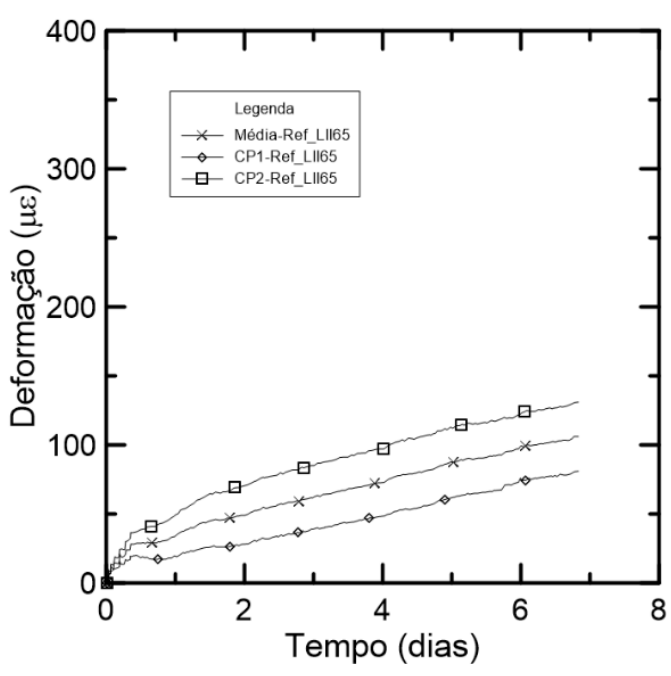

(b)

Figura 0.16 - Deformação por fluência básica: (a) deformação total e (b) sem deformação elástica dos corpos de prova de referência com cimento lote II

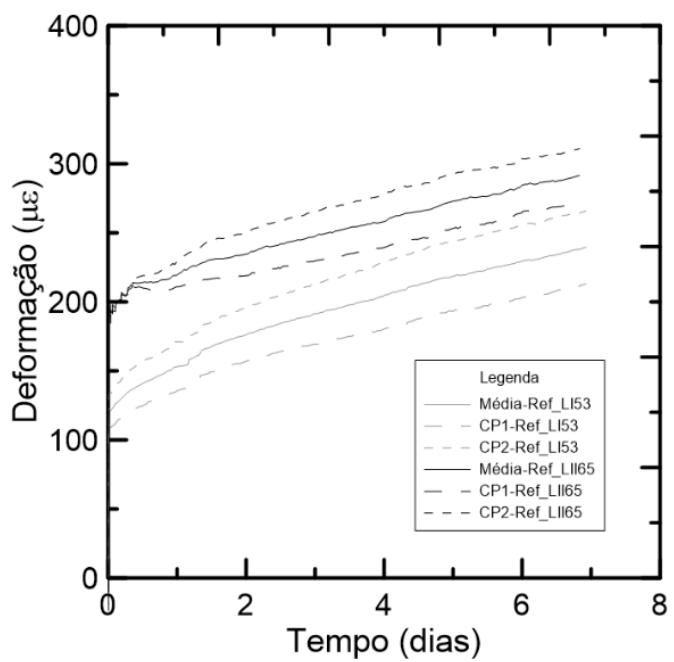

(a)

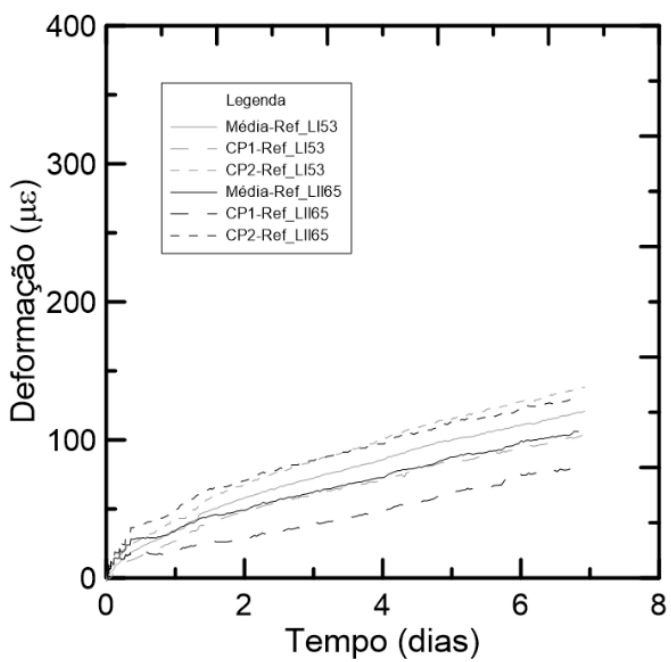

(b)

Figura 0.17 - Deformação por fluência básica: (a) deformação total e (b) sem deformação elástica dos corpos de prova com cimento dos lotes I e II 


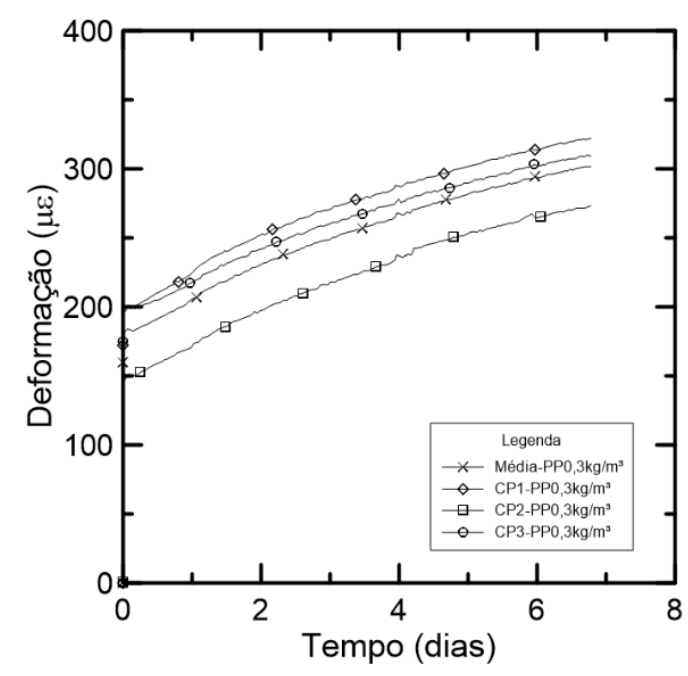

(a)

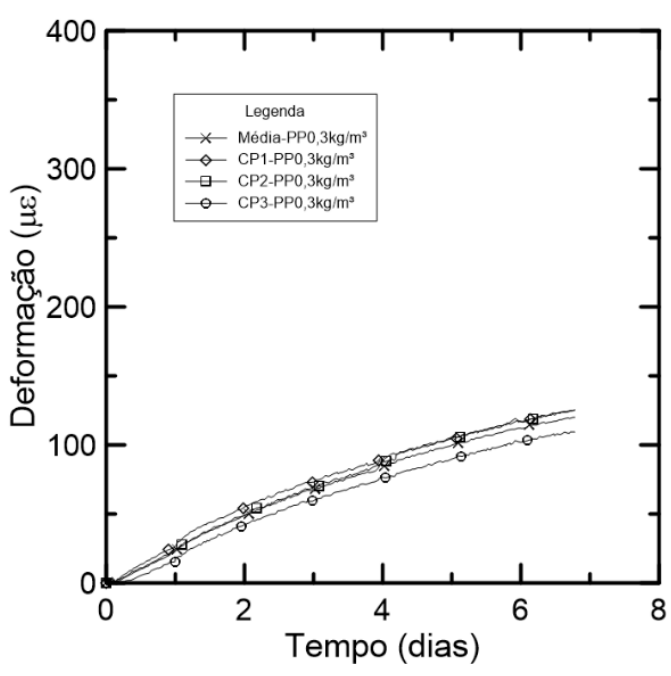

(b)

Figura 0.18 - Deformação por fluência básica: (a) deformação total e (b) sem deformação elástica dos corpos de prova com adição de $0,3 \mathrm{~kg} / \mathrm{m}^{3}$ de PP

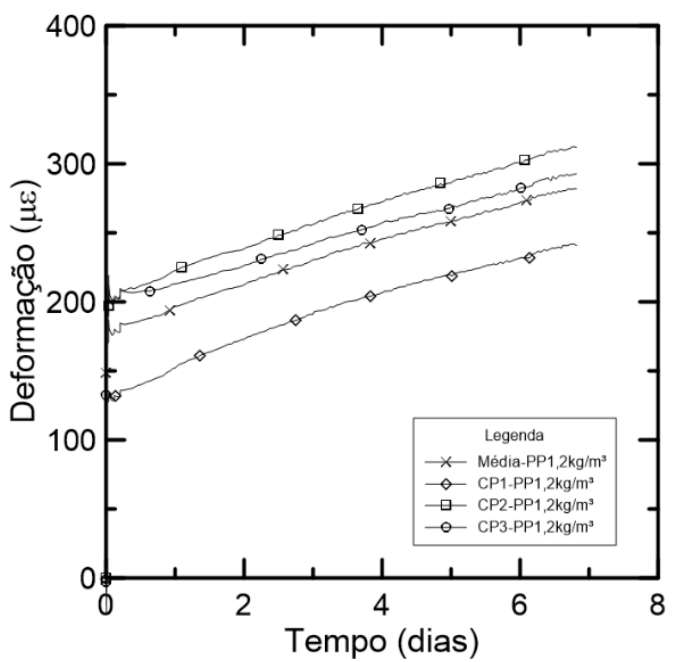

(a)

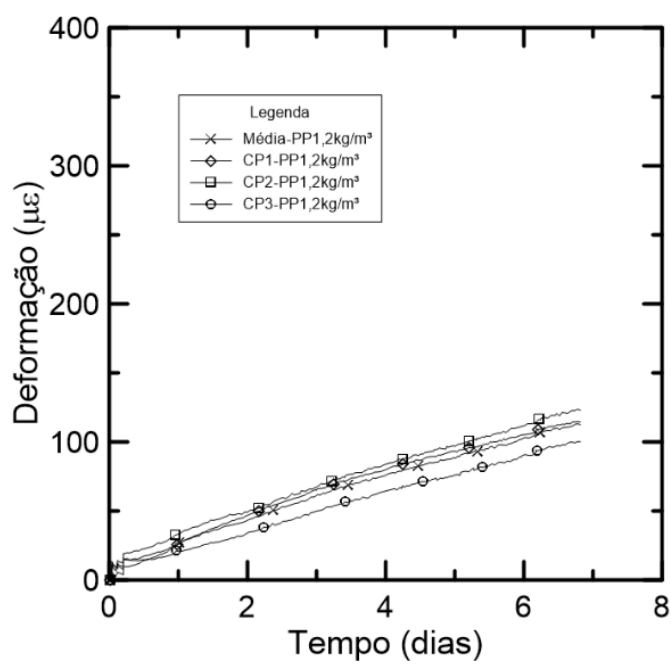

(b)

Figura 0.19 - Deformação por fluência básica: (a) deformação total e (b) sem deformação elástica dos corpos de prova com adição de $1,2 \mathrm{~kg} / \mathrm{m}^{3}$ de PP 


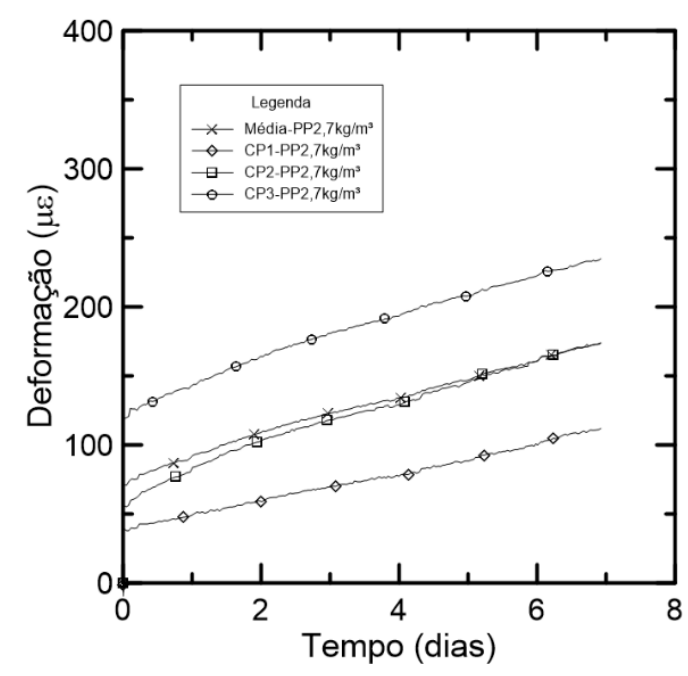

(a)

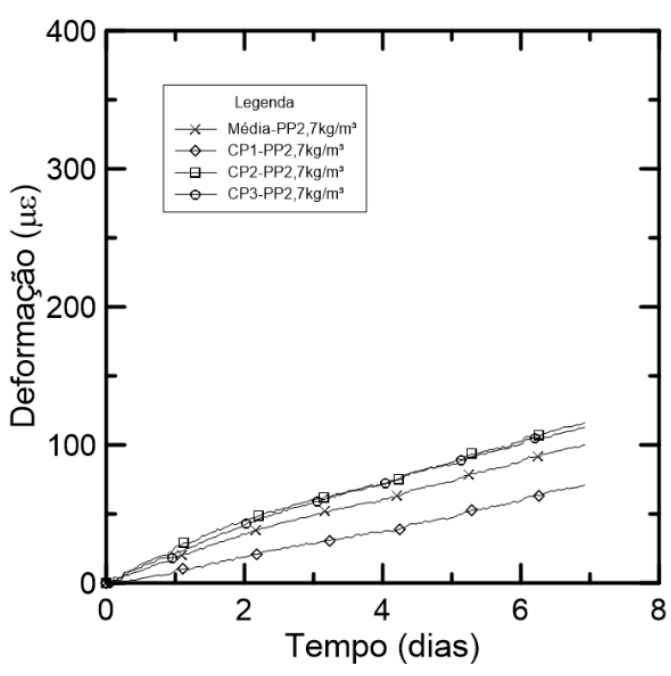

(b)

Figura 0.20 - Deformação por fluência básica: (a) deformação total e (b) sem deformação elástica dos corpos de prova com adição de $2,7 \mathrm{~kg} / \mathrm{m}^{3}$ de PP

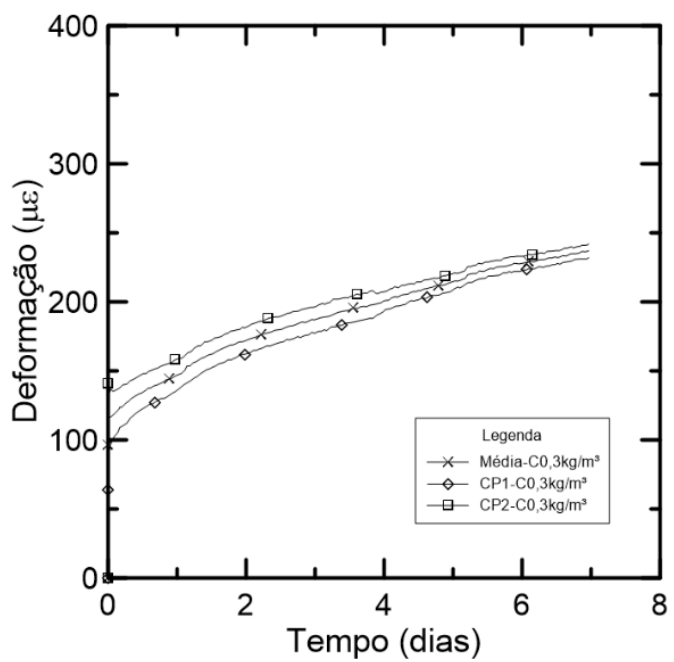

(a)

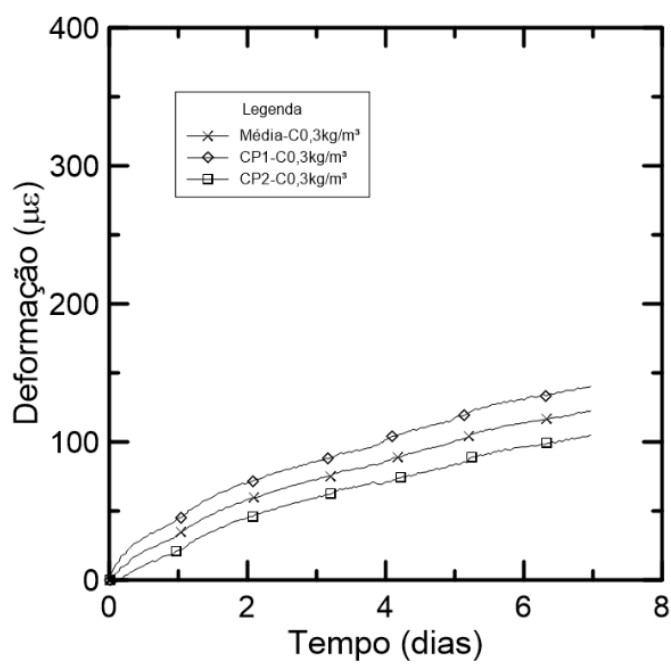

(b)

Figura 0.21 - Deformação por fluência básica: (a) deformação total e (b) sem deformação elástica dos corpos de prova com adição de $0,3 \mathrm{~kg} / \mathrm{m}^{3}$ de curauá 


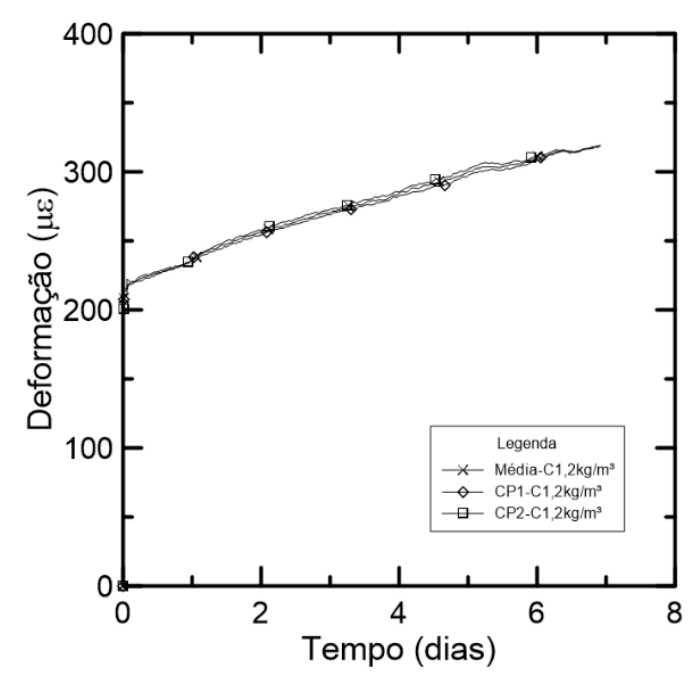

(a)

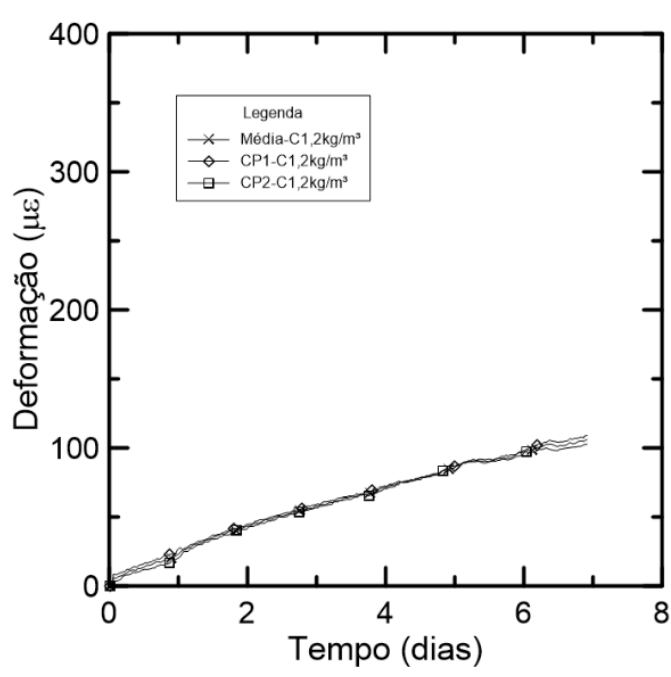

(b)

Figura 0.22- Deformação por fluência básica: (a) deformação total e (b) sem deformação elástica dos corpos de prova com adição de $1,2 \mathrm{~kg} / \mathrm{m}^{3}$ de curauá

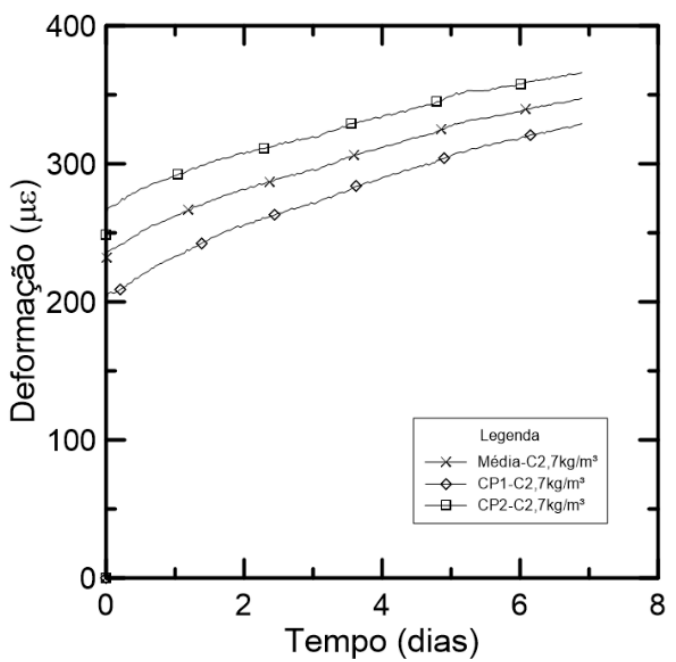

(a)

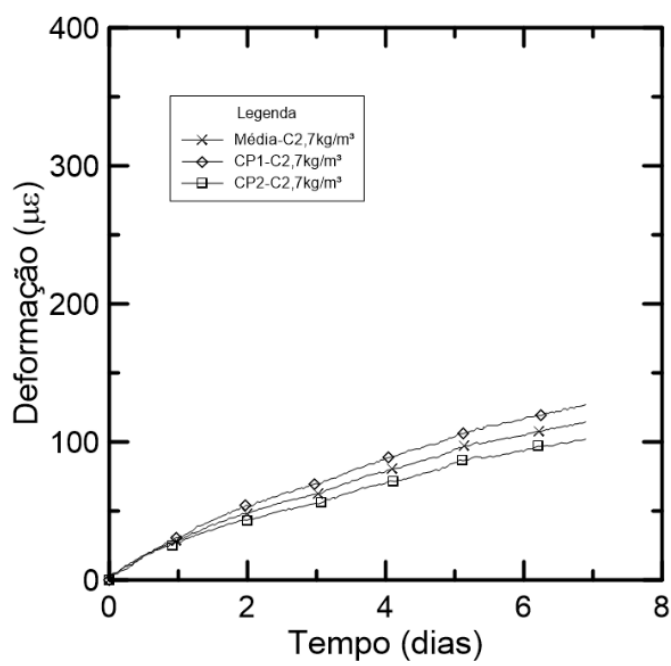

(b)

Figura 0.23 - Deformação por fluência básica: (a) deformação total e (b) sem deformação elástica dos corpos de prova com adição de $2,7 \mathrm{~kg} / \mathrm{m}^{3}$ de curauá 